Prepared in cooperation with the Association to Preserve Cape Cod, the Cape Cod Commission, and the Massachusetts Environmental Trust

\title{
Potential Effects of Sea-Level Rise on the Depth to Saturated Sediments of the Sagamore and Monomoy Flow Lenses on Cape Cod, Massachusetts
}

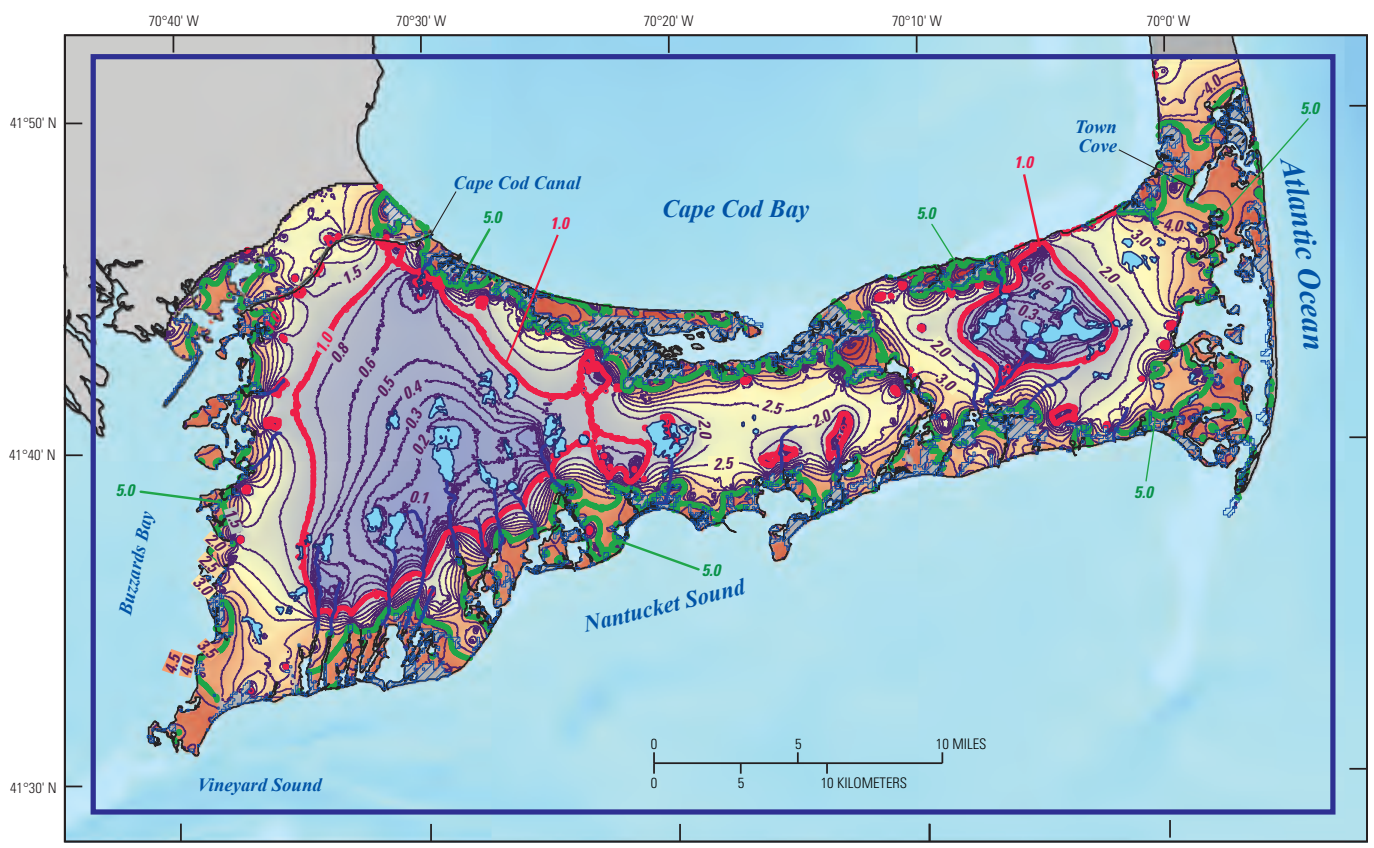

Scientific Investigations Report 2016-5058 Version 1.1, October 2016

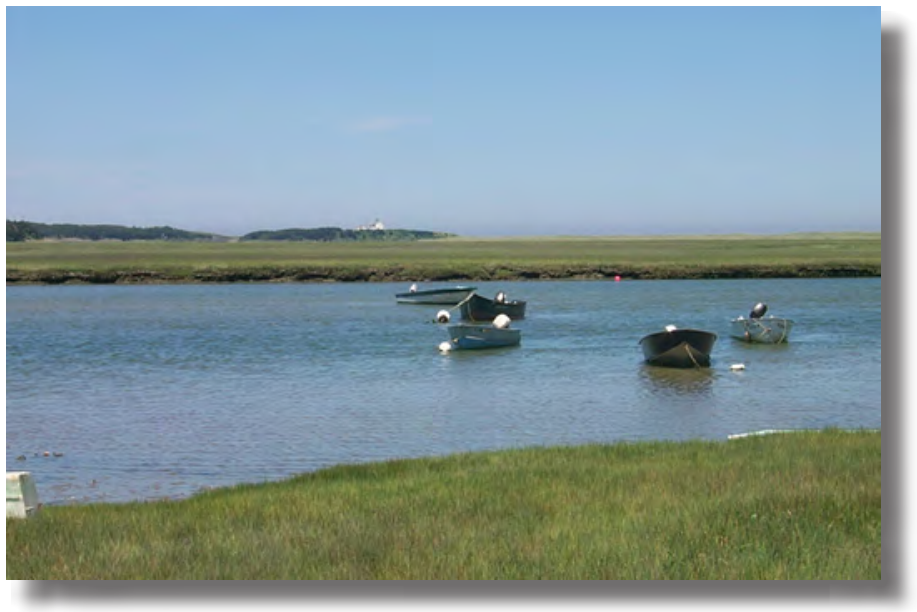


Cover. Map showing change in water table altitude on Cape Cod, Massachusetts; from figure 24 of this report. Photograph of Nauset Marsh, looking northeast toward Coast Guard Beach in Eastham, Mass.; by Timothy D. McCobb. 


\section{Potential Effects of Sea-Level Rise on the Depth to Saturated Sediments of the Sagamore and Monomoy Flow Lenses on Cape Cod, Massachusetts}

By Donald A. Walter, Timothy D. McCobb, John P. Masterson, and Michael N. Fienen

Prepared in cooperation with the

Association to Preserve Cape Cod, the Cape Cod Commission, and the Massachusetts Environmental Trust

Scientific Investigations Report 2016-5058

Version 1.1, October 2016 


\title{
U.S. Department of the Interior SALLY JEWELL, Secretary
}

\section{U.S. Geological Survey Suzette M. Kimball, Director}

\author{
U.S. Geological Survey, Reston, Virginia: 2016 \\ First release: 2016 \\ Revised: October 12, 2016 (ver. 1.1)
}

For more information on the USGS —-the Federal source for science about the Earth, its natural and living resources, natural hazards, and the environment-visit http://www.usgs.gov or call 1-888-ASK-USGS.

For an overview of USGS information products, including maps, imagery, and publications, visit http://store.usgs.gov.

Any use of trade, firm, or product names is for descriptive purposes only and does not imply endorsement by the U.S. Government.

Although this information product, for the most part, is in the public domain, it also may contain copyrighted materials as noted in the text. Permission to reproduce copyrighted items must be secured from the copyright owner.

Suggested citation:

Walter, D.A., McCobb, T.D., Masterson, J.P., and Fienen, M.N., 2016, Potential effects of sea-level rise on the depth to saturated sediments of the Sagamore and Monomoy flow lenses on Cape Cod, Massachusetts (ver. 1.1, October 12, 2016): U.S. Geological Survey Scientific Investigations Report 2016-5058, 55 p., http://dx.doi.org/10.3133/ sir20165058.

ISSN 2328-0328 (online) 


\section{Contents}

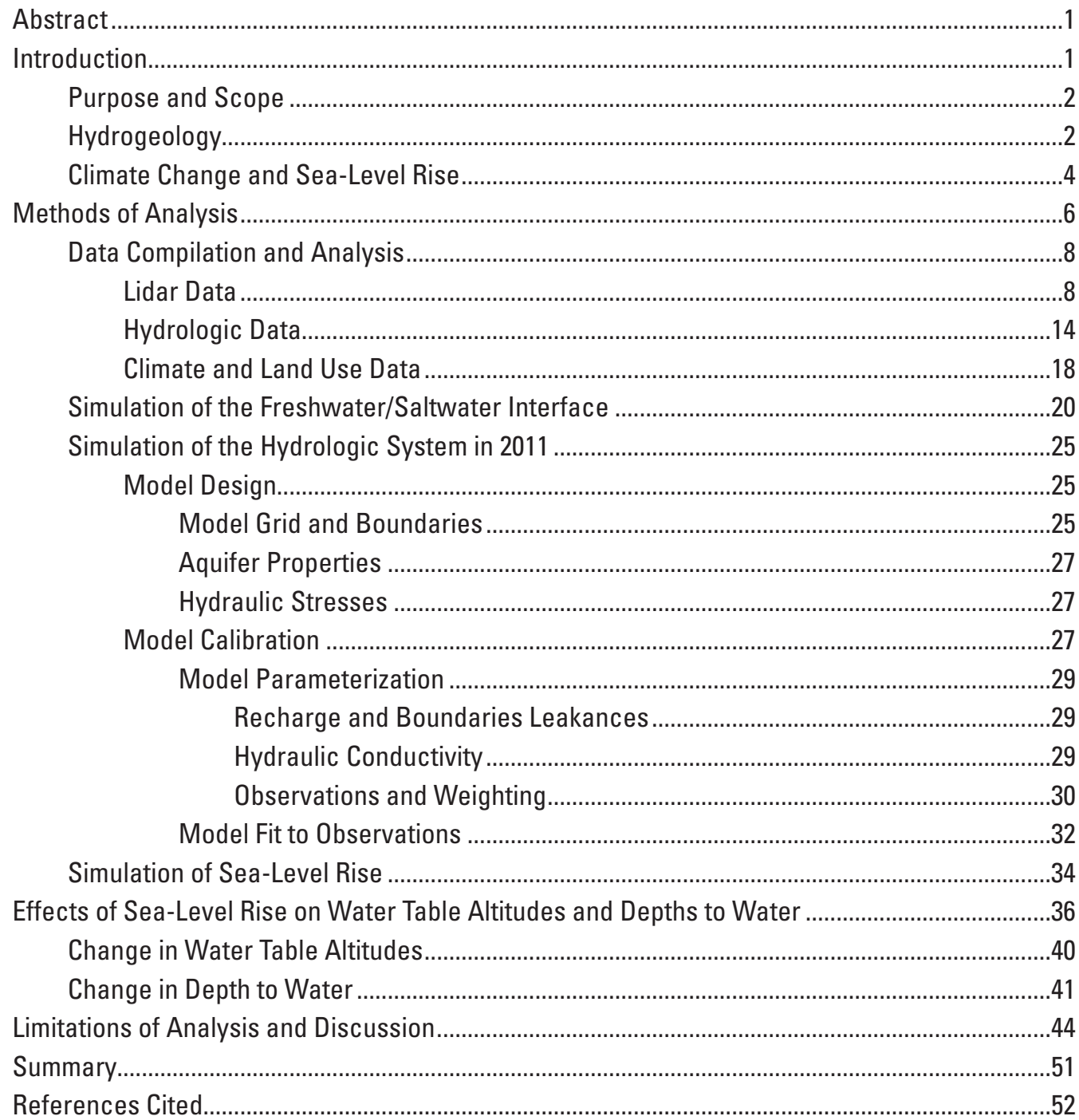

\section{Figures}

1. A, Map showing regional water table and location of Sagamore and Monomoy flow lenses on Cape Cod, Massachusetts. $B$, Generalized hydrologic cross section though western Cape Cod..

2. A, Map showing surficial geology in central and western Cape Cod, Massachusetts. $B$, Geologic cross section through western Cape Cod, Massachusetts.

3. Schematic diagram showing an unconfined coastal aquifer system, similar to the aquifer underlying Cape Cod, Massachusetts, $A$, at static conditions and $B$, after elevation of the sea level.

4. A, Map showing location of tiles of light detection and ranging (lidar) images used in models of central and western Cape Cod, Massachusetts, and detail views of $B$, lidar values within tile 03824616 and surrounding land-surface averaged at a 100 -foot (ft) resolution and $C, 1$-meter-resolution lidar image within the $100-\mathrm{ft}$ cell at row 627 , column 878 
5. Map showing land-surface altitude averaged at 100 -foot resolution derived from 1-meter light detection and ranging data for central and western Cape Cod, Massachusetts.

6. Maps showing range in 1-meter light detection and ranging (lidar) altitude (North American Vertical Datum of 1988) within 100-foot (ft) analysis blocks for $A$, central and western Cape Cod and $B$, Falmouth and Bourne, Massachusetts. $C$, Histogram of lidar values within 100-ft analysis blocks from the Buzzards Bay moraine and the Mashpee outwash on western Cape Cod.

7. Maps showing coastline geometries estimated from 1-meter light detection and ranging data for sea level in 2011 and 6 feet above sea level in 2011 and for areas of potential seawater inundation in $A$, Brewster and $B$, Falmouth on Cape Cod, Massachusetts.

8. Maps showing coastal geometry estimated from 1-meter light detection and ranging data and examples where assumptions of static coastal landforms may not be valid; $A$, a barrier-island breach in Chatham, and $B$, a potential back-barrier coastal pond at Stewarts Creek in Barnstable on Cape Cod, Massachusetts

9. A, Map showing locations of the National Oceanic and Atmospheric Administration weather station (precipitation gage) at Hyannis, Barnstable Municipal—Boardman Airport (KHYA) in Hyannis, Massachusetts, groundwater monitoring wells, and streamflow sites on Cape Cod, Mass., and $B$, graph showing precipitation at the KHYA precipitation gage and streamflow from long-term well MA-SDW 253 in Sandwich County, Mass., and U.S. Geological Survey continuous-record streamgage 011058837 Quashnet River at Waquoit Village, Mass.

10. Graphs showing $A$, water table altitude at U.S. Geological Survey (USGS) long-term monitoring well MA-SDW 253 and partial record monitoring well 27MW0023Al and $B$, maintenance of variance extension (MOVE.1) analysis for USGS partial-record streamgage 0100588340 Santuit River at Old Kings Highway...

11. Map showing annual average recharge rates on Cape Cod, Massachusetts, estimated using the Soil-Water Balance model

12. Map showing extent of previously published models of coastal aquifers for southeastern Massachusetts and new model for central and western Cape Cod, Mass.

13. Map showing the extent of a two-dimensional coastal model, hydrologic boundaries, bedrock altitudes, and areas of the aquifer underlain by saline groundwater in 2011 as simulated by the model for central and western Cape Cod, Massachusetts.

14. Cross sections showing simulated altitude of the freshwater/saltwater interface in central and western Cape Cod, Massachusetts, for sea level in 2011 along $A$ and $B$, east-west sections and $C$, a north-south section

15. A, Map showing model extent and hydrologic boundaries, locations of potential back-barrier coastal ponds, and simulated water table for 2010-11 from a threedimensional groundwater flow model of central and western Cape Cod, Massachusetts. $B$, Cross section showing model layering along an east-west cross section and $C$, detail of model column 419 , row 150 of model.

16. Map showing location of production wells in 2010 and return flow estimated from parcel-scale water use for central and western Cape Cod, Massachusetts .

17. A, Map showing parameter zones and locations of pilot-point parameters for the groundwater flow model of the Sagamore and Monomoy flow lenses on Cape Cod, Massachusetts. $B$, Cross section along row 170 of the model showing vertical parameter groups 
18. Graph showing absolute mean residuals for head and streamflow observation groups for four model variants with increasing geologic constraints.

19. Graphs showing $A$, observed water levels and simulated equivalents and $B$, distribution of head residuals with simulated equivalents for calibrated model of the Sagamore and Monomoy flow lenses, Cape Cod, Massachusetts

20. Graph showing observed and simulated streamflows for highly weighted observations for calibrated model of central and western Cape Cod, Massachusetts

21. Maps showing coastal geometry estimated from 1-meter light detection and ranging data assuming static coastal landforms and simulated hydrologic boundaries for $A$, sea level in 2011 and $B$, sea level 6 feet above 2011 sea level in Falmouth on Cape Cod, Massachusetts

22. Cross section showing model layers and boundaries for simulation of sea level in 2011 and sea levels 2, 4, and 6 feet above 2011 sea levels along an east-west cross section through the model of the Sagamore and Monomoy flow lenses, Cape Cod, Massachusetts.

23. A, Map showing simulated water table for current conditions and $B$, graph showing general hydrologic budget for the Sagamore and Monomoy flow lenses, central and western Cape Cod, Massachusetts

24. Map showing change in water table altitude and fractional change as a function of sea level resulting from a sea-level rise of 6 feet above sea levels in 2011 for central and western Cape Cod, Massachusetts.

25. Graphs showing depth to water for $A$, sea level in 2011 and $B, 2, C, 4$, and $D, 6$ feet above sea levels in 2011 in central and western Cape Cod, Massachusetts.

26. Map showing depth to water resulting from a sea-level rise of 6 feet above sea levels in 2011 and areas with depths to water less than or equal to 5 feet for sea levels in 2011 and 6 feet above sea levels in 2011 in central and western Cape Cod, Massachusetts.

27. Maps showing depth to water resulting from a sea level 6 feet above sea levels in 2011 and areas with depths to water less than or equal to 5 feet for sea levels in 2011 and 6 feet above sea levels in 2011 for $A$, parts of Yarmouth, Dennis, and Harwich and $B$, Falmouth, Mashpee, and Bourne on Cape Cod, Massachusetts.

28. Map showing standard deviation of 1-meter light detection and ranging (lidar) data points within 100 -foot analysis blocks and absolute mean head residuals for the Sagamore and Monomoly flow lenses, Cape Cod, Massachusetts.

29. Maps showing differences between mean and minimum 1-meter light detection and ranging (lidar) values within 100 -foot (ft) analysis blocks and areas with depth to water less than or equal to $5 \mathrm{ft}$ for sea levels in 2011 and $6 \mathrm{ft}$ above sea levels in 2011 for $A$, parts of Falmouth, Mashpee, Bourne, and Sandwich and B, Yarmouth, Dennis, and Harwich on Cape Cod, Massachusetts

30. Maps showing changes in altitude of $A$, the simulated freshwater/saltwater interface and $B$, hydraulic head resulting from a barrier breach and formation of a potential new estuary for a sea level 6 feet above sea level in 2011 in Barnstable, Cape Cod, Massachusetts

\section{Table}

1. Response of land area, water table altitudes, and depths to water for the Sagamore and Monomoy flow lenses to sea-level rises of 2, 4, and 6 feet above 2011 levels. 


\section{Conversion Factors}

U.S. customary units to International System of Units

\begin{tabular}{lll}
\hline \multicolumn{1}{c}{ Multiply } & \multicolumn{1}{c}{ By } & \multicolumn{1}{c}{ To obtain } \\
\hline inch (in.) & 2.54 & centimeter $(\mathrm{cm})$ \\
foot (ft) & 0.3048 & meter $(\mathrm{m})$ \\
mile $(\mathrm{mi})$ & 1.609 & kilometer $(\mathrm{km})$ \\
square mile $\left(\mathrm{mi}^{2}\right)$ & 2.590 & square kilometer $\left(\mathrm{km}^{2}\right)$ \\
cubic foot per second $\left(\mathrm{ft}^{3} / \mathrm{s}\right)$ & 0.02832 & cubic meter per second $\left(\mathrm{m}^{3} / \mathrm{s}\right)$ \\
million gallons per day $(\mathrm{Mgal} / \mathrm{d})$ & 0.04381 & cubic meter per second $\left(\mathrm{m}^{3} / \mathrm{s}\right)$ \\
foot per day $(\mathrm{ft} / \mathrm{d})$ & 0.3048 & meter per day $(\mathrm{m} / \mathrm{d})$ \\
inch per hour $(\mathrm{in} / \mathrm{h})$ & 0.0254 & meter per hour $(\mathrm{m} / \mathrm{h})$ \\
\hline
\end{tabular}

\section{Datum}

Vertical coordinate information is referenced to the North American Vertical Datum of 1988 (NAVD 88) and National Geodetic Vertical Datum of 1929 (NGVD 29).

Horizontal coordinate information is referenced to the North American Datum of 1983 (NAD 83).

Altitude, as used in this report, refers to distance above the vertical datum.

\section{Abbreviations}

$2 \mathrm{D}$

two dimensional

$3 \mathrm{D}$

three dimensional

APCC

Association to Preserve Cape Cod

CCC

Cape Cod Commission

lidar

light detection and ranging

MEP

Massachusetts Estuaries Project

NOAA

National Oceanic and Atmospheric Administration

NRCS

Natural Resources Conservation Service

NWIS

National Water Information System

NWS

National Weather Service

$\mathrm{RCH}$

Recharge package

SLR

sea-level rise

SVD

singular-value decomposition

SVDA

SVD Assist [software]

SWB

soil-water balance

USDA

U.S. Department of Agriculture

USGS

U.S. Geological Survey 


\title{
Potential Effects of Sea-Level Rise on the Depth to Saturated Sediments of the Sagamore and Monomoy Flow Lenses on Cape Cod, Massachusetts
}

\author{
By Donald A. Walter, Timothy D. McCobb, John P. Masterson, and Michael N. Fienen
}

\section{Abstract}

In 2014, the U.S. Geological Survey, in cooperation with the Association to Preserve Cape Cod, the Cape Cod Commission, and the Massachusetts Environmental Trust, began an evaluation of the potential effects of sealevel rise on water table altitudes and depths to water on central and western Cape Cod, Massachusetts. Increases in atmospheric and oceanic temperatures arising, in part, from the release of greenhouse gases likely will result in higher sea levels globally. Increasing water table altitudes in shallow, unconfined coastal aquifer systems could adversely affect infrastructure - roads, utilities, basements, and septic systems - particularly in low-lying urbanized areas. The Sagamore and Monomoy flow lenses on Cape Cod are the largest and most populous of the six flow lenses that comprise the region's aquifer system, the Cape Cod glacial aquifer. The potential effects of sea-level rise on water table altitude and depths to water were evaluated by use of numerical models of the region. The Sagamore and Monomoy flow lenses have a number of large surface water drainages that receive a substantial amount of groundwater discharge, 47 and 29 percent of the total, respectively. The median increase in the simulated water table altitude following a 6-foot sea-level rise across both flow lenses was 2.11 feet, or 35 percent when expressed as a percentage of the total sea-level rise. The response is nearly the same as the sea-level rise ( 6 feet) in some coastal areas and less than 0.1 foot near some large inland streams. Median water table responses differ substantially between the Sagamore and Monomoy flow lenses - at 29 and 49 percent, respectively - because larger surface water discharge on the Sagamore flow lens results in increased dampening of the water table response than in the Monomoy flow lens. Surface waters dampen water table altitude increases because streams are fixed-altitude boundaries that cause hydraulic gradients and streamflow to increase as sea-level rises, partially fixing the local water table altitude.

The region has a generally thick vadose zone with a mean of about 38 feet; areas with depths to water of 5 feet or less, as estimated from light detection and ranging (lidar) data from
2011 and simulated water table altitudes, currently [2011] occur over about 24.9 square miles, or about 8.4 percent of the total land area of the Sagamore and Monomoy flow lenses, generally in low-lying coastal areas and inland near ponds and streams. Excluding potentially submerged areas, an additional $4.5,9.8$, and 15.9 square miles would have shallow depths to water ( 5 feet or less) for projected sea-level rises of 2, 4, and 6 feet above levels in 2011. The additional areas with shallow depths to water generally occur in the same areas as the areas with current [2011] depths to water of 5 feet or less: low-lying coastal areas and near inland surface water features. Additional areas with shallow depths to water for the largest sea-level rise prediction (6 feet) account for about 5.7 percent of the total land area, excluding areas likely to be inundated by seawater. The numerous surface water drainages will dampen the response of the water table to sea-level rise. This dampening, combined with the region's thick vadose zone, likely will mitigate the potential for groundwater inundation in most areas. The potential does exist for groundwater inundation in some areas, but the effects of sea-level rise on depths to water and infrastructure likely will not be substantial on a regional level.

\section{Introduction}

Coastal areas worldwide are susceptible to the adverse effects of rising sea levels that result from increasing global temperatures. Potential critical effects of sea-level rise include surface water inundation of low-lying areas near saltwater bodies and, when coupled with more frequent storms, an increase in coastal flooding resulting from higher storm surges. Sea-level rise also will affect coastal groundwater systems. These effects, while not as manifest as coastal inundation and storm surge, likely will have significant long-term economic and social implications. About half (47 percent) of the U.S. population will live in coastal communities by 2020 (National Oceanic and Atmospheric Administration, National Weather Service, 2015b), a large part of which relies on coastal aquifers for potable water. Potential effects on these 
aquifer systems include an increase in water table altitudes, streamflow, and potential saltwater intrusion. Increases in water table altitude and the converse decrease in the distance between the water table and land surface are referred to as groundwater inundation and, like surface water inundation, can adversely affect infrastructure in coastal areas (Flood and Cahoon, 2011). Saltwater intrusion also can affect watersupply wells in some coastal areas (Werner and Simmons, 2009; Langevin and Zygnerski, 2013).

Cape Cod is a developing coastal region in southeastern Massachusetts (fig. 1) where the population more than doubled between 1970 and 2010 (Cape Cod Commission, 2012); the region's communities rely on an underlying unconfined coastal aquifer for potable water. The Cape Cod aquifer is bounded laterally by saltwater bodies, and sea level is the base level for the aquifer. As a result, water table altitudes likely will increase as sea-level rises, and depths to water could decrease below thresholds critical for infrastructure in some areas; types of infrastructure that could be affected include basements, roads, septic systems, sewer lines, and utilities. The complex response of the water table to sea-level rise and resultant changes in depths to water are a function of several factors, including land surface altitude, surface water drainages, coastal geometry, and the position of the freshwater/saltwater interface. Sea-level rise and resulting groundwater inundation has been identified as having potential effects on infrastructure in urbanized areas (Bjerklie and others, 2012) and on natural ecosystems (Masterson and others, 2013).

In 2014, the U.S. Geological Survey (USGS), in cooperation with the Association to Preserve Cape Cod (APCC), the Cape Cod Commission (CCC), and the Massachusetts Environmental Trust, began an evaluation of the potential effects of sea-level rise on water table altitudes and depths to water on central and western Cape Cod, the most populous and urbanized parts of the region. The investigation included analyses of land surface altitudes for the region as determined from light detection and ranging (lidar) data from 2011 and development of a set of numerical models capable of simulating the response of the Cape Cod aquifer - water table altitudes, streamflow, and the position of the freshwater/saltwater interface - to changes in sea level. Coincident land surface and simulated water table altitudes were combined to estimate depths to water for sea levels in 2011 and a range of possible future sea levels and to identify areas where potential groundwater inundation and risks to infrastructure are greatest.

\section{Purpose and Scope}

This report discusses the potential effects of sea-level rise on the vertical separation between land surface and the water table on central and western Cape Cod. The report presents information on estimates of sea-level rise and the rationale for the set of sea-level rise scenarios used in this analysis. The report also discusses the regional hydrogeology of the region and the potential effects of sea-level rise on water table altitudes and depths to water as wells as the factors that can affect the water table response to rising sea level. The analysis uses USGS lidar data from 2011 in conjunction with a set groundwater-flow models; this report includes documentation of these analytical methods and numerical models. The processing of detailed (1-meter [m]-resolution) lidar data to define a seamless mosaic of land surface across the study area and to delineate coastline geometry in 2011 and projected to 2100 also is discussed. The report also documents modifications of an existing two-dimensional (2D) regional model capable of simulating the freshwater/saltwater interface and development and calibration of a new, three-dimensional (3D) numerical model capable of simulating water levels and streamflows. The discussion includes comparisons between observed hydrologic conditions and hydrologic conditions simulated by the 3D model, and structural changes to the 3D model to facilitate the simulation of the hydrologic system at different sea levels.

The response of the water table to rising sea levels are presented, and the depths to water for sea level in 2011 and sea levels at 2, 4, and 6 feet (ft) above 2011 sea levels projected to occur by 2100 are reported and discussed. The complex interaction between streams and land surface and the water table and the resulting effects on the water table response are presented. Areas where surface waters may dampen increases in water table altitude are identified. Depths to water for current and future sea levels are summarized in histograms. An expanded analysis is presented for a regional response, and detailed maps identify areas where shallow depths to water are more likely to occur. Limitations of and assumptions inherent in the analysis are discussed. Errors in predictions of water table altitude and those associated with upscaled land surface altitudes, as determined from lidar data, are presented and compared. Examples of changing coastal landforms and potential violations of the assumption of static coastal landforms are presented. The potential effects of changing coastal landforms on the hydrologic system, particularly near back-barrier coastal ponds, and its implications are discussed.

\section{Hydrogeology}

Cape Cod is underlain by unconsolidated sediments that generally are highly permeable and nearly $1,000 \mathrm{ft}$ thick in some areas. The region receives substantial rainfall, and the unconsolidated sediments compose the sole source of potable water for the region's communities. The Cape Cod aquifer is unconfined and consists of six separate flow lenses: Sagamore, Monomoy, Nauset, Chequesset, Pamet, and Pilgrim (fig. 1). Each flow lens represents a distinct aquifer system that is hydraulically separate from adjacent flow lenses. The Sagamore and Monomoy flow lenses on western and central Cape Cod, respectively, are the two largest (fig. 1). The geologic history and hydrology of Cape Cod have been documented in numerous publications, including LeBlanc and others (1986), Oldale (1992), Uchupi and others (1996), and Masterson and others (1997a). The glacial sediments, which 


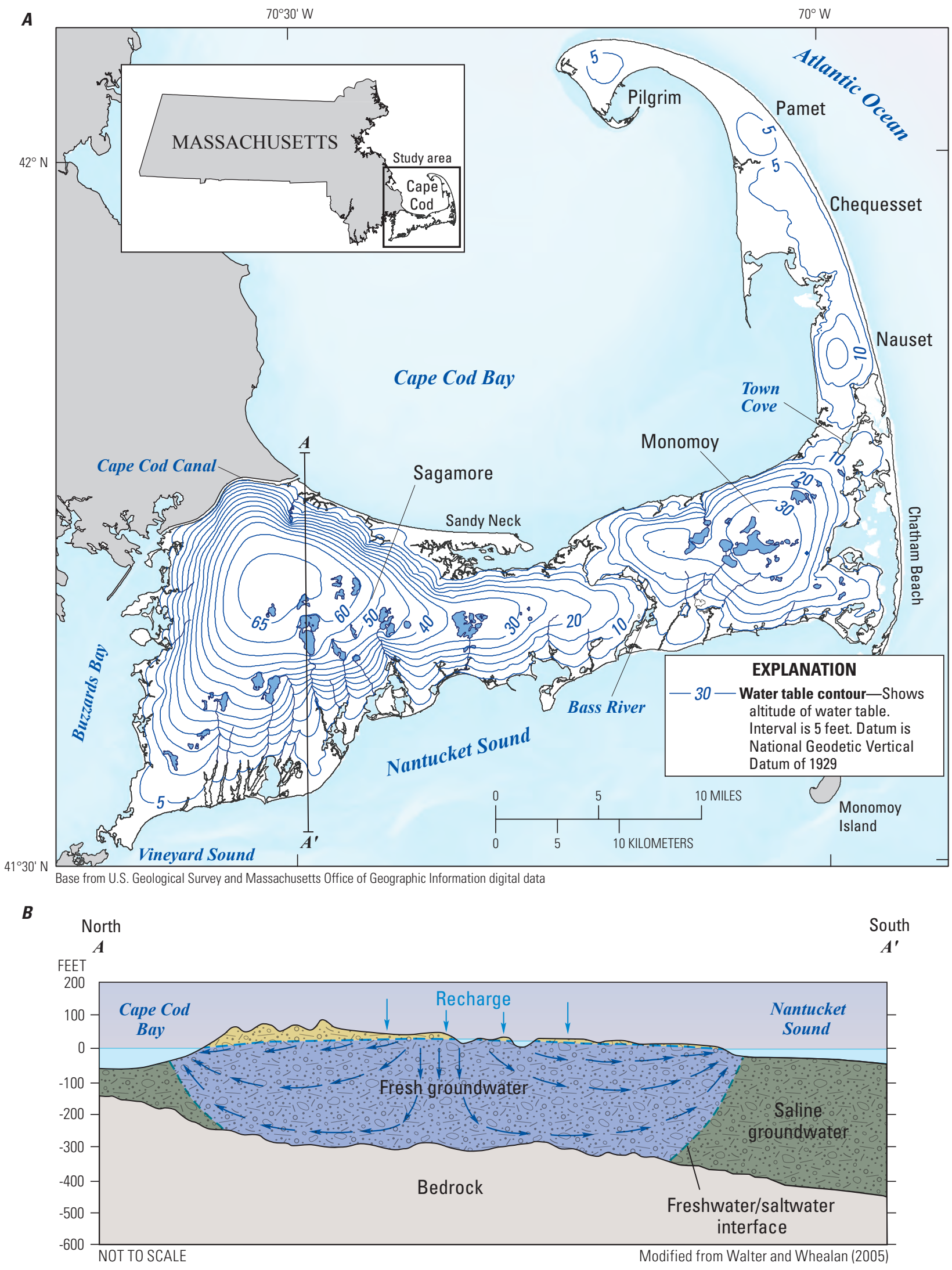

Figure 1. A, Regional water table and location of Sagamore and Monomoy flow lenses on Cape Cod, Massachusetts. $B$, Generalized hydrologic cross section though western Cape Cod; location of cross section shown in figure $1 A$. 
consist of clay, gravel, sand, and silt and are underlain by crystalline bedrock, were deposited 15,000 to 16,000 years ago within and near the margins of retreating continental ice sheets (Oldale, 1992; Uchupi and others, 1996). The altitude of the bedrock surface underlying the glacial sediments ranges from about $50 \mathrm{ft}$ below the National Geodetic Vertical Datum of 1929 (NGVD 29) near the Cape Cod Canal to more than $500 \mathrm{ft}$ below NGVD 29 beneath the central part of the Monomoy flow lens (Fairchild and others, 2012; Byron Stone, U.S. Geological Survey, written commun., 1997]).

The surficial geology of Cape Cod is characterized by broad, gently sloping outwash plains and hummocky terrain associated with glacial moraines and ice-contact deposits (fig. 2; Stone and DiGiacomo-Cohen, 2009). Land surface altitude exceeds $200 \mathrm{ft}$ near the Cape Cod Canal and is less than $50 \mathrm{ft}$ over broad areas in south-central Cape Cod (fig. 2A). Outwash sediments, which compose most of the glacial sediments underlying Cape Cod, were deposited in fluvial and lacustrine depositional environments associated with proglacial lake deltas analogous to those seen in present-day fluvial deltas (Oldale, 1992). Moraines were deposited in low-energy environments at the margins of the ice sheets and generally are finer grained and less sorted than outwash sediments; ice-contact deposits were deposited within high-energy fluvial environments beneath and inside the ice sheets and generally are coarser grained than outwash deposits.

Outwash sediments generally become finer grained with depth and to the south with increasing distance from sediment sources (fig. 2B; Masterson and others, 1997a). These deposits are broadly divided into three depositional units: coarse-grained sand and gravel deposited in meltwater streams (topset beds), fine- to medium-grained sands deposited in near shore lacustrine environments (foreset beds), and fine-grained sand and silt deposited in offshore lacustrine environments (bottomset beds; Masterson and others (1997a; fig. $2 B$ ). Geologic contacts generally are absent laterally within depositional units, and grain size trends are gradational. Numerous kettle holes occur within the outwash plain; these collapse structures were formed by the melting of buried blocks of remnant glacial ice and the subsequent collapse of the overlying sediments; many kettle holes now contain ponds.

The unconsolidated glacial sediments underlying Cape Cod compose an unconfined aquifer system that is bounded above by a free-surface water table and laterally by salt water: Cape Cod Bay to the north, the Cape Cod Canal to the northwest, Buzzards Bay to the west, Nantucket Sound to the south, and the Atlantic Ocean to the east (fig. 1). The Sagamore flow lens is the largest and westernmost of the six hydraulically distinct freshwater flow lenses that underlie Cape Cod (fig. 1); the flow lens is hydraulically separated at its northwestern extent from mainland Massachusetts by the Cape Cod Canal and from the adjacent Monomoy flow lens at its eastern extent by the Bass River (fig. 1). The adjacent Monomoy flow lens extends from the Bass River at its westernmost extent to Town Cove, which separates it from the adjacent Nauset flow lens (fig. 1). The aquifer is bounded below in most areas by impermeable bedrock rather than the freshwater/saltwater interface; the altitude of the interface that would represent a hydrostatic balance between freshwater and saltwater (Drabbe and Ghyben, 1888; Herzberg, 1901) generally is much deeper than the bedrock surface in most areas. The lower boundary of the aquifer in areas near the coast is a sharp freshwater/ saltwater interface (LeBlanc and others, 1986), representing a general mass balance between the less dense freshwater and the more dense saltwater. Recharge from precipitation is the sole source of water to the aquifer. About 45 inches per year (in/yr; 1,143 millimeters per year [mm/yr]) of precipitation falls on Cape Cod; slightly more than half of the precipitation recharges the aquifer across the water table (LeBlanc and others, 1986); the remainder is lost to evapotranspiration. Surface runoff is negligible owing to the sandy soils and low topographic relief of the area.

Water table altitudes exceed $65 \mathrm{ft}$ above NGVD 29 in the northwestern part of the Sagamore flow lens (fig. 1A) and $30 \mathrm{ft}$ above NGVD 29 in the north-central Monomoy flow lens. Groundwater flows radially from these regional groundwater divides toward natural discharge locations in streams, coastal estuaries, and the ocean (fig. 1). Most groundwater flows through shallow sediments and discharges to streams and estuaries; groundwater recharging the aquifer near groundwater divides flows deep into the aquifer and discharges offshore to the ocean (fig. 1B). Water table contours and groundwater-flow patterns are strongly affected locally by ponds and streams. Kettle-hole ponds are in hydraulic connection to the aquifer; groundwater-flow paths converge upgradient of the ponds, where groundwater discharges into the ponds, and diverge in downgradient areas, where pond water recharges the aquifer. Some ponds have surface water outlets that drain into freshwater streams. Streams generally are areas of groundwater discharge (gaining streams) and receive water from the aquifer. Some stream reaches may lose water to the aquifer (losing streams), particularly in areas downgradient from pond outflows; however, these generally are limited in extent.

\section{Climate Change and Sea-Level Rise}

The release of anthropogenic compounds into the atmosphere, primarily from fossil-fuel emissions, likely has caused an anomalous increase in mean atmospheric and oceanic temperatures since the mid-20th century; the rate of warming likely will increase through the 21 st century and beyond (Pachauri and Meyer, 2014). Adverse societal effects of global warming include changes in precipitation patterns and droughts, diminished crop production, an increase in the frequency and intensity of coastal storms, and an increase in global mean sea level. The latter results from thermal expansion of the ocean and, more significantly, from the loss of glacial ice and melting of the Greenland and Antarctic ice sheets (Williams and Hall, 1993). The observed rate of ice loss has been increasing since the early 1990s and likely will continue 


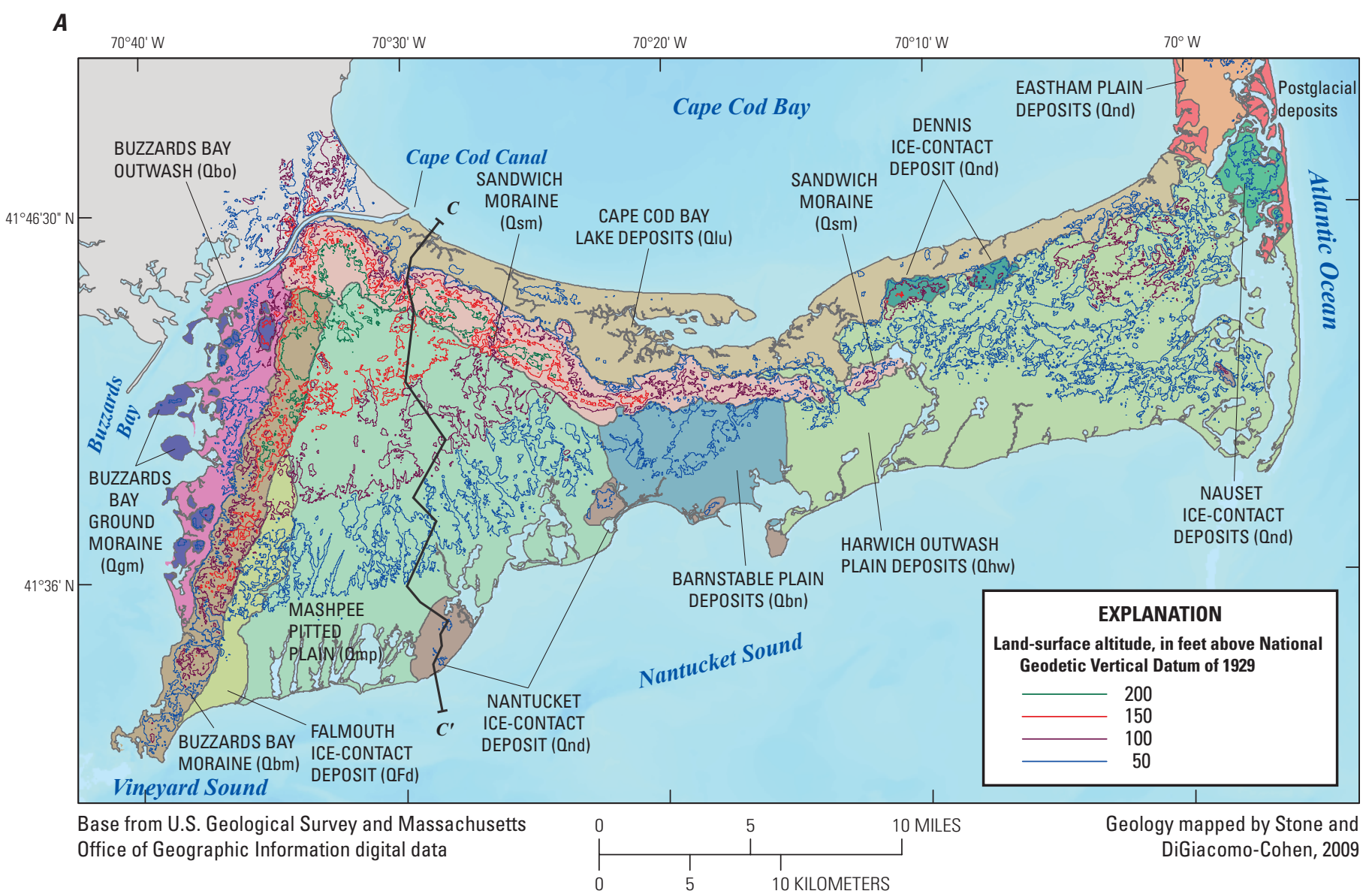

B

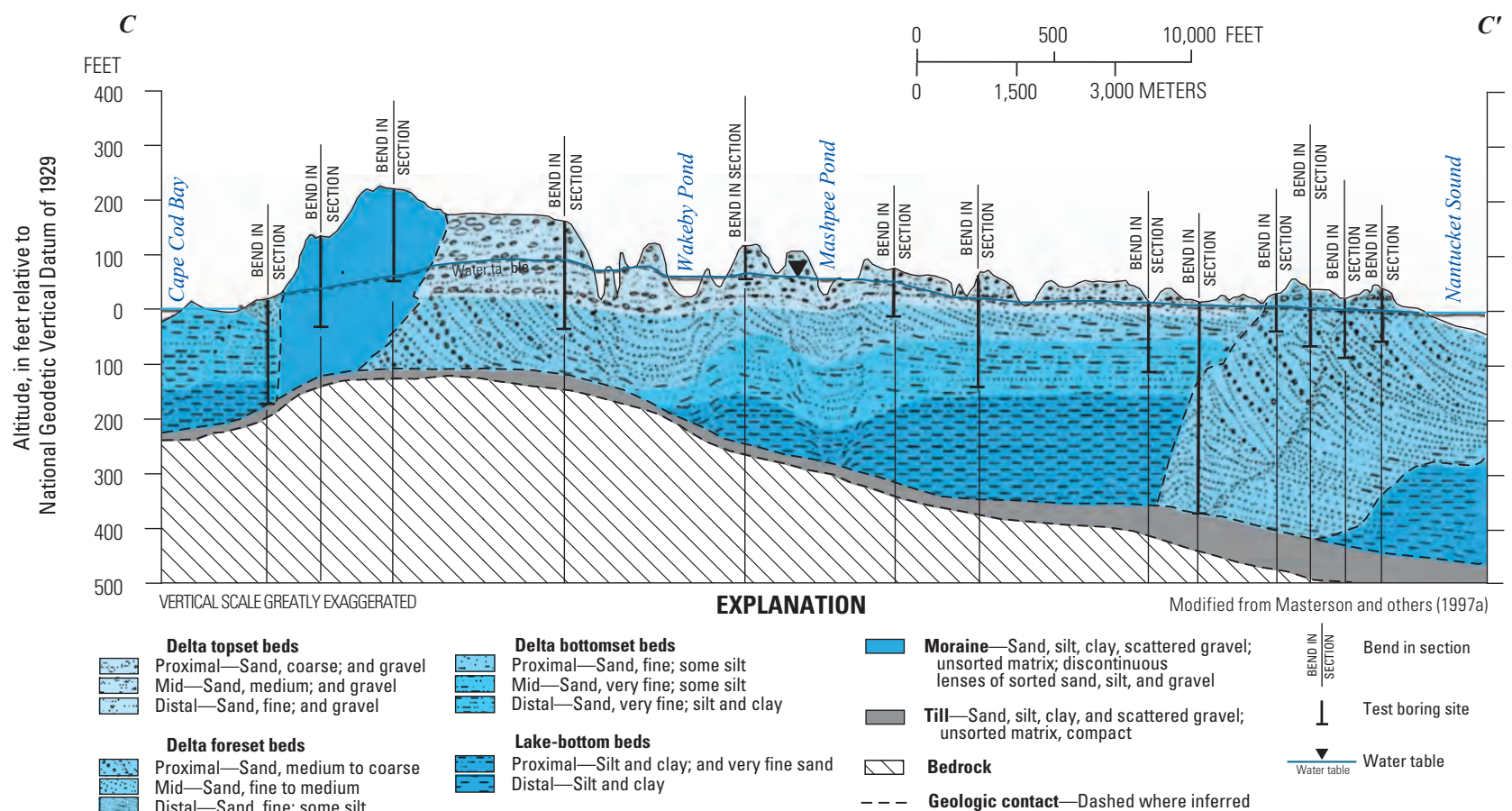

Figure 2. A, Surficial geology in central and western Cape Cod, Massachusetts. B, Geologic cross section through western Cape Cod, Massachusetts; location of cross section shown in figure $2 A$. 
to increase through the 21st century (Pachauri and Meyer, 2014). Global mean sea level increased by an average rate of about 0.06 to 0.07 inches per year (in/yr [1.5 to $1.9 \mathrm{~mm} / \mathrm{yr}]$ ) from 1901 to 2010; sea-level rise in the latter part of the period (after 1990) averaged 0.11 to $0.14 \mathrm{in} / \mathrm{yr}$ ( 2.8 to $3.6 \mathrm{~mm} / \mathrm{yr}$ ), indicating that rates of sea-level rise are increasing.

Projections of future sea-level rise vary greatly owing to a number of factors, including differing emission and warming projections, oceanic circulation patterns, and ice-sheet dynamics. Evaluation of emission scenarios and the resulting global temperature increases yielded a range of predicted sealevel rise between about 1.5 and $2.5 \mathrm{ft}(0.45$ and $0.75 \mathrm{~m})$ by 2100 (Pachauri and Meyer, 2014); the mean of these sea-level rise predictions was about $2 \mathrm{ft}$. Most predictions do not fully account for ice-sheet dynamics, but highly nonlinear, catastrophic processes, such as grounding-line migration of the Greenland ice sheet from basal meltwater or collapse of the West Antarctic ice sheet, would increase sea level well above these predictions. Evidence of ice-sheet instability in the Antarctic (Parizek and others, 2013; Favier and others, 2014) and increased ice velocities from basal meltwater in Greenland (Phillips and others, 2013) have been reported.

Projections of sea-level rise used for estimation of societal impacts and adaptive planning vary globally and in the United States range from about $4.9 \mathrm{ft}(1.5 \mathrm{~m}$; U.S. Army Corps of Engineers, 2011) to $6.6 \mathrm{ft}$ ( $2 \mathrm{~m}$; Paris and others, 2012) by 2100. A comprehensive analysis of sea-level rise prediction probability suggests that the near-upper limit (95th percentile) of predicted sea-level rise, including consideration of ice-sheet dynamics, is about $5.9 \mathrm{ft}(1.9 \mathrm{~m})$ by 2100 (Jevrejeva and others, 2014). Sea-level rises over broad regions may be several times smaller or larger than the global mean (Pachauri and Meyer, 2014). Changing salinities from meltwater could disrupt and slow ocean currents, contributing to additional sealevel rise in some areas. Disruption of the Gulf stream likely will lead to higher than average sea level along parts of the eastern United States, from the mid-Atlantic to the Northeast (Ezer and others, 2013) and there is evidence of accelerated sea-level rise in the northeastern Unites States and eastern Canada as of 2011 (Boon, 2012). The mean rate of sea-level rise on Cape Cod from 1901 to 2002 exceeded the upper end of the global range for roughly the same period, about $2 \mathrm{~mm} / \mathrm{yr}$ (Masterson, 2004), suggesting that sea-level rise generally could be greater on Cape Cod than most other regions.

The base level of shallow, unconfined aquifers, such as those underlying Cape Cod, is sea level. The altitude of the water table and of the freshwater/saltwater interface increase as sea level increases at hydrologic boundaries (fig. 3). Hydraulic gradients at boundaries, discharge rates, and the thickness of the freshwater aquifer generally remain the same if recharge into the system remains the same and there are no surface water outlets or a thin vadose zone, but the presence of surface water outlets can cause a thinning of the freshwater flow lens (Masterson and Garabedian, 2007). Streambeds have a fixed altitude, so hydraulic gradients increase near surface water outlets as the water table rises in response to rising sea level. As a result, streamflow increases, and the increased outflow from the aquifer is balanced locally by upward movement of the freshwater/saltwater interface (fig. 3). New areas of groundwater seepage also may form at land surface in areas with a thin unsaturated zone.

Land surface is a fixed altitude, so the separation distance between land surface and the water table - referred to here as depth to water-decreases by the same amount as the water table altitude increases. Decreases in depths to water can adversely affect infrastructure, such as basements, buried utilities, roads, and septic systems (fig. 3). The increase in water table altitude (and decrease in depth to water) would generally be equal to sea-level rise in a hypothetical unconfined aquifer bounded on all sides by the ocean, with no surface water outlets, and a land surface above the water table in all areas (Masterson and Garabedian, 2007). Many coastal aquifers, including those underlying Cape Cod, are far more complex systems and include ponds, streams, and potential areas of land surface seepage. These features are expected to result in a more complex and nonlinear water table response to sea-level rise and a possible dampening of water table increases. Therefore, a detailed analysis of reliable land surface altitude data and process models capable of representing the groundwater system under different sea level regimes is required.

\section{Methods of Analysis}

Evaluating changes in depths to water in response to rising sea level requires defining two independent surfaces: a fixed land surface and a water table for each sea level to be evaluated. A detailed rendering of the land surface for central and western Cape Cod was developed from lidar data from 2011. Water table altitude was estimated for different sea levels by use of a three-dimensional (3D) groundwater-flow model implicitly linked to a two-dimensional (2D) model capable of simulating the regional freshwater/saltwater interface; the linkage was done by incorporating the position of fresh/salt water interface computed from the 2D model into the 3D model. The 3D groundwater-flow model was calibrated to observations of water table altitude and streamflow. The 3D calibrated model was modified to represent sea levels of 2, 4, and $6 \mathrm{ft}$ above the 2011 sea level and simulate water table altitudes corresponding to those sea levels. The simulated future water tables were used in conjunction with the lidar-derived land surface to evaluate changes in depths to water in response to the higher sea levels. The spatial resolutions of the lidar data and the discretization of the 3D groundwater-flow model differ substantially, at $3.28 \mathrm{ft}(1 \mathrm{~m})$ and $400 \mathrm{ft}$, respectively. A resolution of $100 \mathrm{ft}$ was used for the depth-to-water analysis, referred to as the analytical scale, by upscaling lidar data using spatial averaging and downscaling model-calculated water table altitudes by interpolation to that common resolution. 
$\boldsymbol{A}$

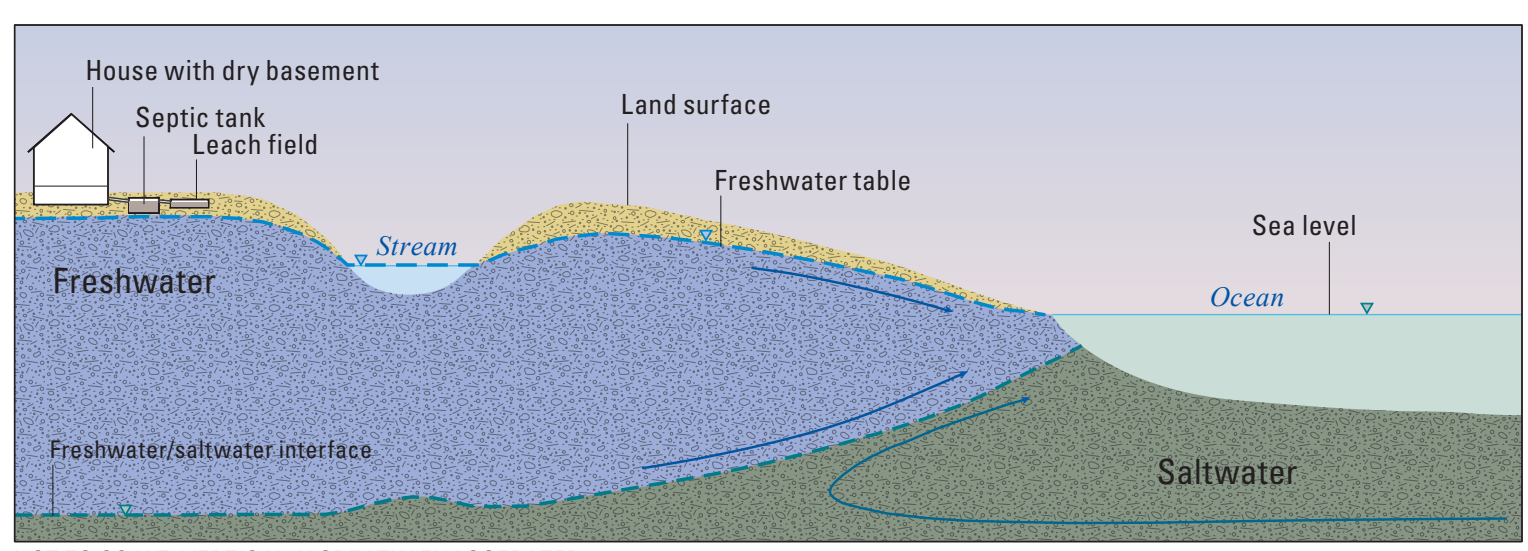

NOT TO SCALE; VERTICALLY GREATLY EXAGGERATED

EXPLANATION

$\checkmark$ Freshwater-level indicator

$\nabla$ Saltwater-level indicator

B

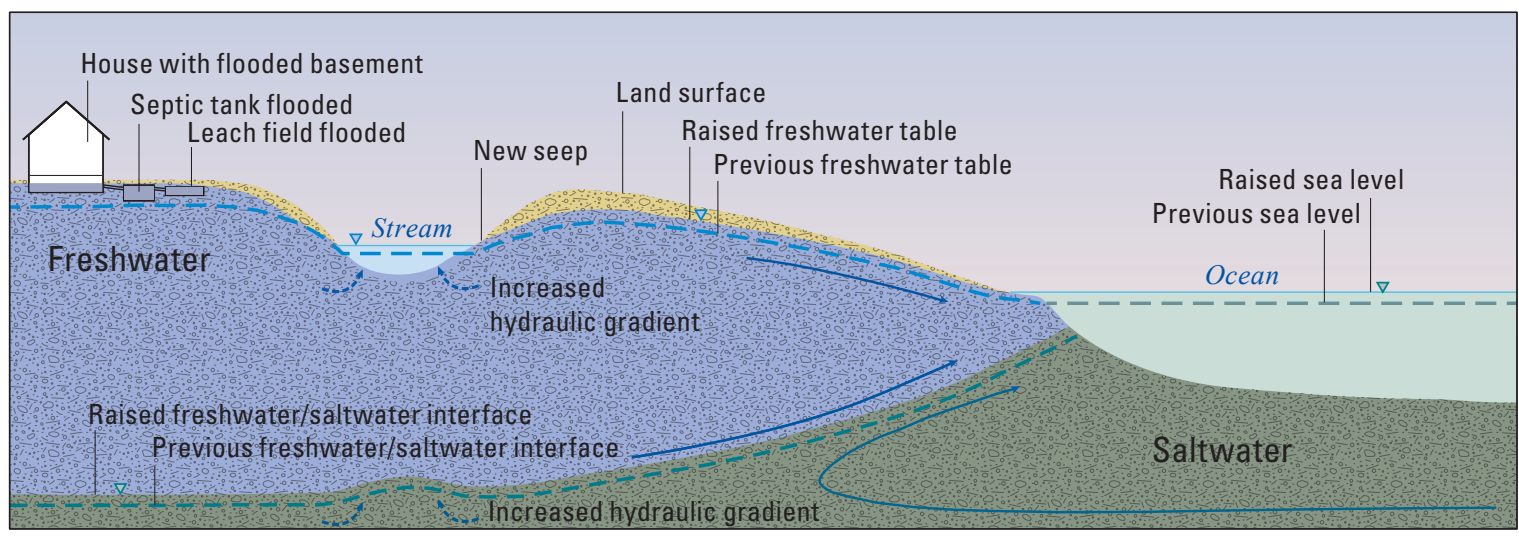

NOT TO SCALE; VERTICALLY GREATLY EXAGGERATED

Figure 3. An unconfined coastal aquifer system, similar to the aquifer underlying Cape Cod, Massachusetts, $A$, at static conditions and $B$, after elevation of the sea level.

The analytical steps for evaluating depths to water for a given sea level are as follows:

- Coastline geometry determined from 1-m-resolution lidar was used to modify the geometry of hydrologic boundaries in the 2D numerical model.

- Specified heads at the boundaries were modified to represent the new sea level and a new freshwater/saltwater interface was simulated.

- This interface position, simulated at a $100-\mathrm{ft}$ resolution, was spatially averaged to $400 \mathrm{ft}$ and incorporated into the $3 \mathrm{D}$ groundwater-flow model as a no-flow boundary.

- Hydrologic boundaries of the groundwater-flow model were modified using the same lidar-derived coastal geometry and the new sea level.
- The groundwater-flow model configured for a given sea level was used to simulate the new water table for that sea level.

- The model-calculated water table altitudes, at a discretization of $400 \mathrm{ft}$, were linearly interpolated to a resolution of $100 \mathrm{ft}$, the same as the spatially averaged lidar land surface altitudes.

- The two surfaces of the model-calculated water table altitudes and the spatially averaged lidar land surface altitudes were used to determine depths to water for the sea level of interest.

- Depths to water were estimated for the 2011 sea level and for sea levels 2, 4, and $6 \mathrm{ft}$ above the 2011 sea level. 
Comparisons of these depths to water to evaluate the effects of sea-level rises exclude areas predicted to be inundated by sea water following a sea level $6 \mathrm{ft}$ above the 2011 sea level for consistency. The numerical models used in the analysis are available in a model archive upon request. The archive contains input and output files for the coastal and 3D groundwater-flow models and the executable files needed to run the models. The archive also contains georeferenced files that can be used to display the 3D groundwater-flow-model finite-difference grid as well as the hydrologic data - water levels and streamflow sites - used in calibration of the 3D groundwater-flow model.

\section{Data Compilation and Analysis}

Three sets of data were compiled and analyzed as part of this investigation: climate and land-use data, hydrologic data (water levels and streamflows) from wells and gaging stations, and estimates of land surface derived from lidar data. Water levels and streamflow for use in calibration of the groundwater-flow model were obtained from the USGS National Water Information System database (http://waterdata.usgs.gov/nwis) and data collected from other sources. Precipitation data were obtained from the National Oceanic and Atmospheric Administration (NOAA) weather station at the Hyannis, Barnstable Municipal-Boardman Airport in Hyannis, Mass. (KHYA; National Oceanic and Atmospheric Administration, 2012). Land-use data were obtained from the Massachusetts Office of Geographic Information (2012), and soil characteristics were obtained from the National Conservation Resources Service (U.S. Department of Agriculture, Natural Conservation Resources Service, 1998, 2013). Land surface altitude data were collected by the USGS lidar program for the Northeastern United States in 2011 (U.S. Geological Survey, 2015) and obtained from the Massachusetts Office of Geographic Information (2014). Bathymetry in offshore areas was compiled from the National Oceanic and Atmospheric Administration at a scale of $98.4 \mathrm{ft}$ (30-m; National Oceanic and Atmospheric Administration, 2015a). Water-use data were compiled from local water suppliers for 2010 , and the distribution of return flow was obtained from the Massachusetts Department of Environmental Protection Massachusetts Estuaries Project (Tom Cambareri, Cape Cod Commission, written commun., 2012).

\section{Lidar Data}

Discrete-return lidar uses reflected pulses of laser light to determine distance from the light source to the illuminated target. The USGS uses aerial deployment to collect lidar data for detailed mapping of land-surface altitude over broad regions. Lidar data were collected for the northeastern United States from New York to Maine in winter to spring 2011. Lidar data were used in this analysis for three purposes: determination of coastal geometries for 2011 sea level and sea levels of 2,
4, and $6 \mathrm{ft}$ above 2011 levels, definition of boundary altitudes at hydrologic boundaries for simulating water table responses to sea-level rise, and determination of depths to water using simulated water table altitudes.

The Cape Cod region is represented by 565 individual uniform lidar tiles (fig. 4A), in digital raster form, each of which consists of 1,500 by 1,500 data points (cells) with a spatial resolution of $3.28 \mathrm{ft}(1 \mathrm{~m})$ for a total of 2.25 million points for each tile (fig. $4 B$ ). The total number of data points for the lidar tiles that encompass central and western Cape Cod exceeds 1 billion, making use of the lidar data at the original 1-m scale intractable. The depth-to-water analysis is at a uniform spatial scale of $100 \mathrm{ft}$, and the area of interest extends from the Cape Cod Canal to Town Cove (fig. 5). The analytical grid has the same extent and resolution $(100 \mathrm{ft})$ as the existing 2D regional model of the Sagamore and Monomoy flow lenses and is coincident with the coarser, $400-\mathrm{ft}$ grid of the 3D groundwater-flow model developed as part of this analysis. The size of the $100-\mathrm{ft}$ analytical gridabout 3.2 million cells - is sufficient to represent depths to water in detail yet still tractable for data analysis given geoprocessing limitations of current technology.

The 1-m lidar data were upscaled to the analytical scale of $100 \mathrm{ft}$ by spatial averaging within each cell in the analytical grid (fig. 4C). Individual data points within each lidar tile were converted to Cartesian coordinates in the same projection as the analytical grid, and the Cartesian position of each point within the grid was computed. Away from coastal areas where parts of some tiles contain no data, there were typically 929 individual data points within each 100 -ft cell (fig. 4C) in the analytical grid. The mean, maximum, minimum, range, and standard deviation of data-point populations for each cell were computed and used to define seamless mosaics of land surface altitude and spatial variability at the $100-\mathrm{ft}$ resolution (fig. 5).

Minimum and maximum values for lidar data points within the population of individual $100-\mathrm{ft}$ cells ranged between 0 and $70 \mathrm{ft}$ and averaged $8.8 \mathrm{ft}$ across the study area; variability within cells generally correlated to the region's surficial geology (fig. 6A). Large variability occurs within the hummocky terrain associated with glacial moraines, and small variability occurs within outwash plains. Individual lidar values within representative 100 -ft cells ranged from $2.1 \mathrm{ft}$ in the Mashpee outwash plain to $49.5 \mathrm{ft}$ the Buzzards Bay moraine (fig. $6 B$ ). The distribution of individual values within the cells differs substantially (fig. 6C). Large variability also occurs near surface features such as erosional channels and kettle holes (fig. 6B). Variability of the lidar data within the larger analytical grid cells potentially introduces a scale-dependent source of uncertainty in predictions of depths to water that are computed using upscaled land surface altitudes.

Coastline geometries were defined from 1-m lidar data by selecting values greater than the sea level of interest: $0 \mathrm{ft}$ relative to the North American Vertical Datum of 1988 (NAVD 88) for the 2011 coastline and 2, 4, and $6 \mathrm{ft}$ above NAVD 88 for future sea levels. Areas with lidar values 


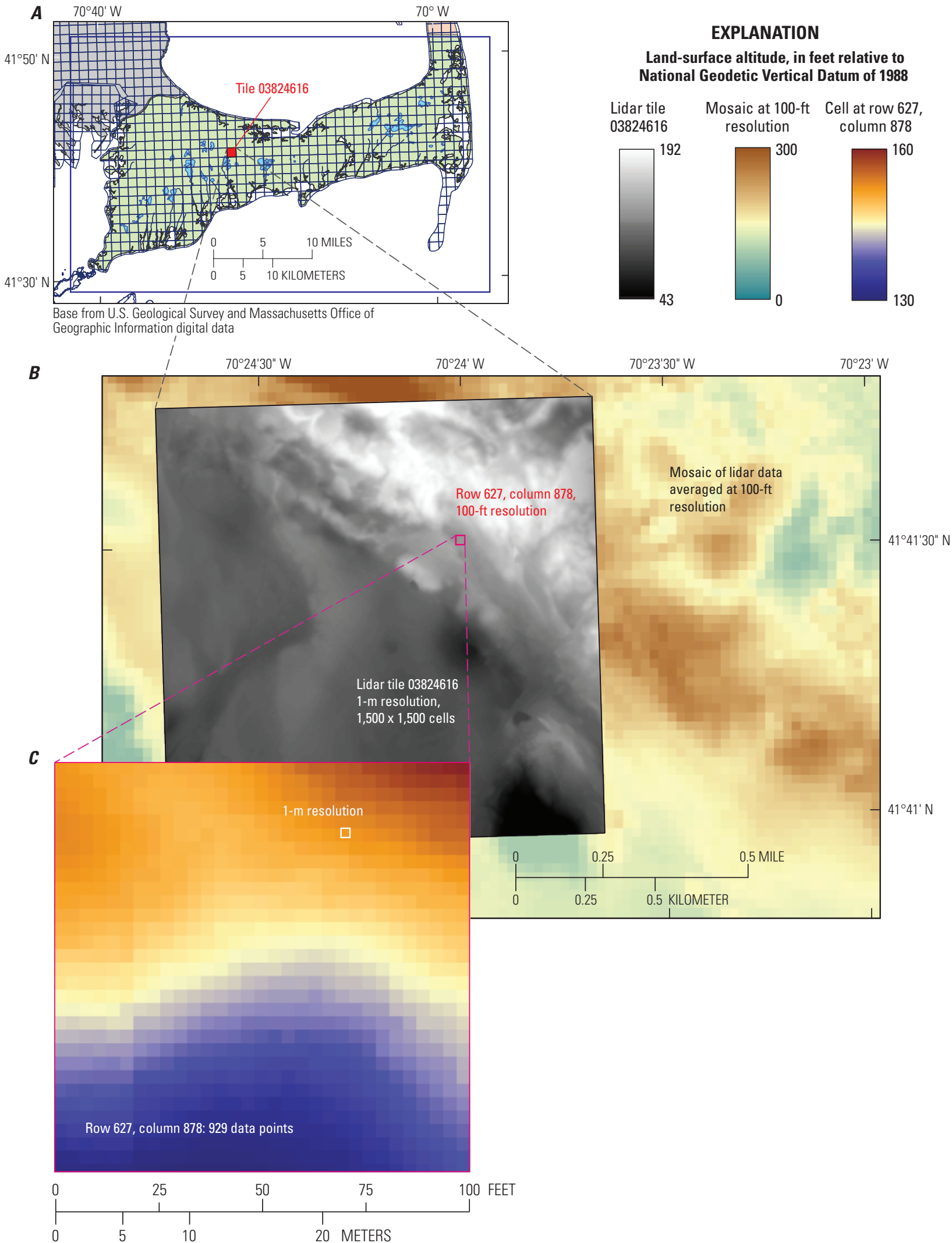

Figure 4. A, Location of tiles of light detection and ranging (lidar) images used in models of central and western Cape Cod, Massachusetts, and detail views of $B$, lidar values within tile 03824616 and surrounding land-surface averaged at a 100foot (ft) resolution and $C, 1$-meter $(\mathrm{m})$-resolution lidar image within the 100-ft cell at row 627, column 878. 


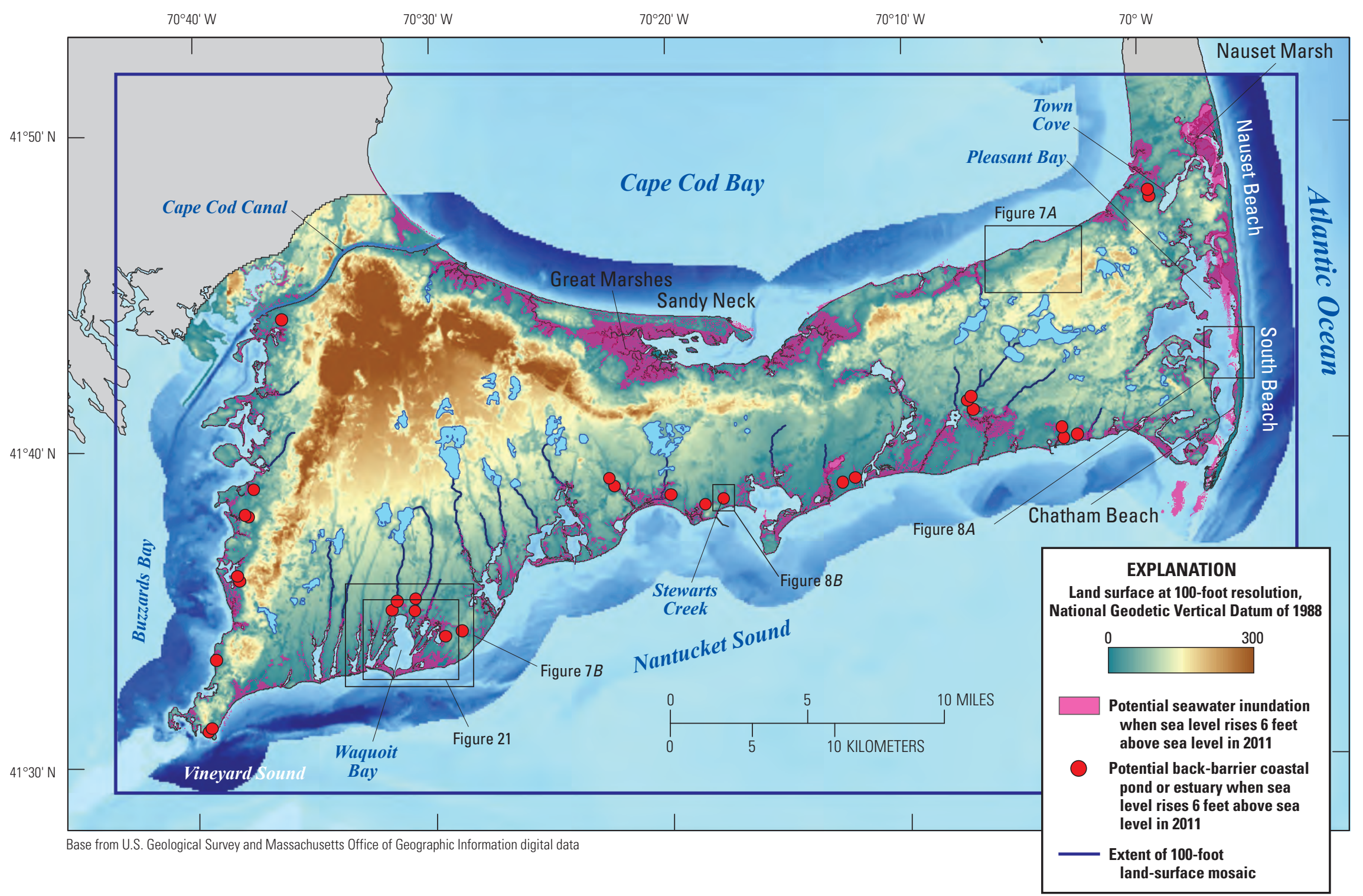

Figure 5. Land-surface altitude averaged at 100-foot (ft) resolution derived from 1-meter light detection and ranging (lidar) data for central and western Cape Cod, Massachusetts. 
$\boldsymbol{A}$
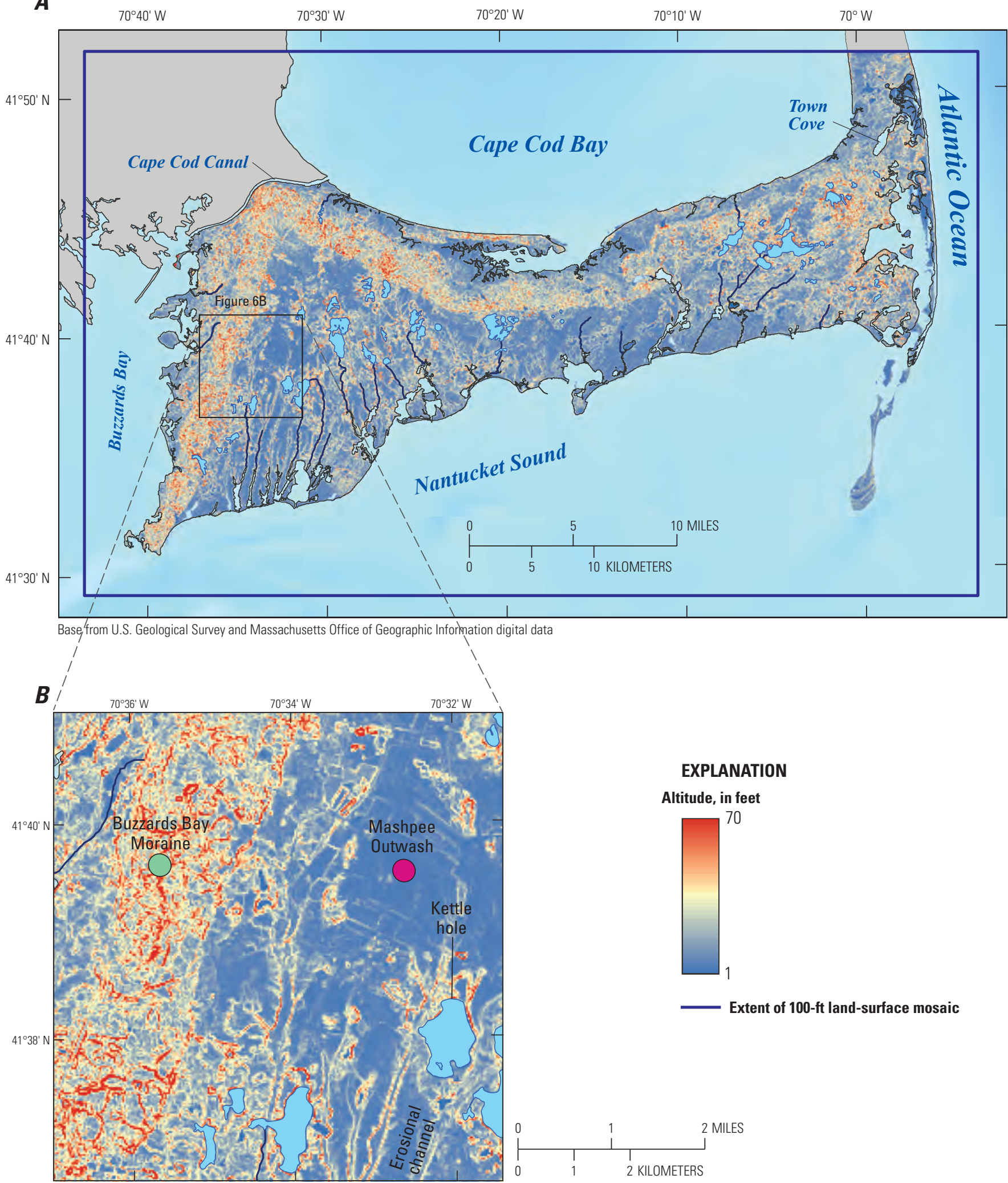

\section{EXPLANATION}

Altitude, in feet

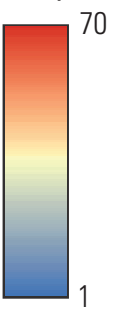

Extent of 100 -ft land-surface mosaic

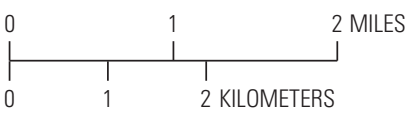

Figure 6. Range in 1-meter light detection and ranging (lidar) altitude (North American Vertical Datum of 1988) within 100-foot (ft) analysis blocks for $A$, central and western Cape $\operatorname{Cod}$ and $B$, Falmouth and Bourne, Massachusetts. $C$, Histogram of lidar values within $100-\mathrm{ft}$ analysis blocks from the Buzzards Bay moraine and the Mashpee outwash on western Cape Cod. 


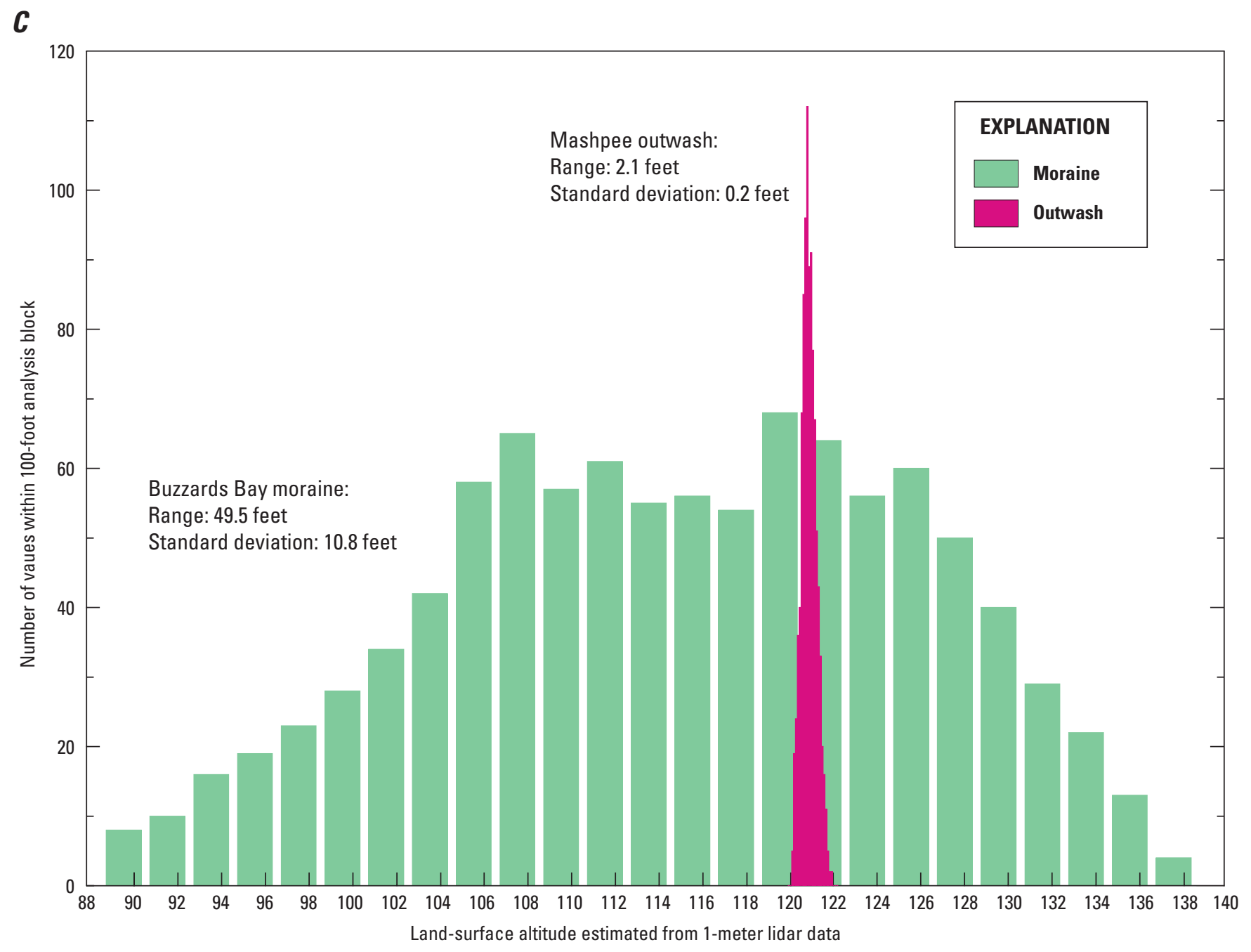

Figure 6. Range in 1-meter light detection and ranging (lidar) altitude (North American Vertical Datum of 1988) within 100-foot (ft) analysis blocks for $A$, central and western Cape Cod and $B$, Falmouth and Bourne, Massachusetts. $C$, Histogram of lidar values within 100-ft analysis blocks from the Buzzards Bay moraine and the Mashpee outwash on western Cape Cod.-Continued

between $0 \mathrm{ft}$ and a given future sea level were assumed to be inundated by sea water at that sea level. The land area of Sagamore and Monomoy flow lenses on western and central Cape Cod, respectively, defined as lidar altitudes greater than $0 \mathrm{ft}$ relative to NAVD 88, excluding ponds and coastal marshes, is about 299 square miles $\left(\mathrm{mi}^{2}\right)$. Future land areas, defined as land surface altitude greater than 2, 4, and $6 \mathrm{ft}$ above NGVD 88 were about 290, 280, and $268 \mathrm{mi}^{2}$, respectively. About 9,19 , and $31 \mathrm{mi}^{2}$ of land area above sea level in 2011 would be inundated in the three sea-level rise scenarios of 2, 4, and $6 \mathrm{ft}$, respectively. Estimates of land area in 2011 and, therefore, the areal extent of seawater inundation are derived by selecting lidar data points greater than $0 \mathrm{ft}$ relative to NAVD 88 but have some uncertainty in low-lying coastal areas. Estimates of land area and seawater inundation in these low-lying coastal areas may include those for large areas of tidal flats and salt marshes, such as Nauset Marsh, Great Marshes, and the northern part of Pleasant Bay (fig. 5); therefore, the areal extent of seawater inundation of dry land would be expected to be lower than these estimates.

Coastline geometry and the areas of seawater inundation differ substantially depending on local coastal topography. Land surface along the northern coast of central and western Cape Cod, adjacent to Cape Cod Bay, generally is higher and gradients steeper than along the southern shore, Nantucket Sound (fig. 5). Extensive areas of seawater inundation along the eastern and northern coasts occur primarily in marginal coastal terrain - tidal flats and salt marshes. In areas where there are steep erosional bluffs, such as around Brewster, Mass., along the northeastern coast of the Monomoy flow lens, coastline geometries are essentially the same, showing very little seawater inundation with increasing sea levels (fig. $7 A$ ). 


\section{A. Brewster}

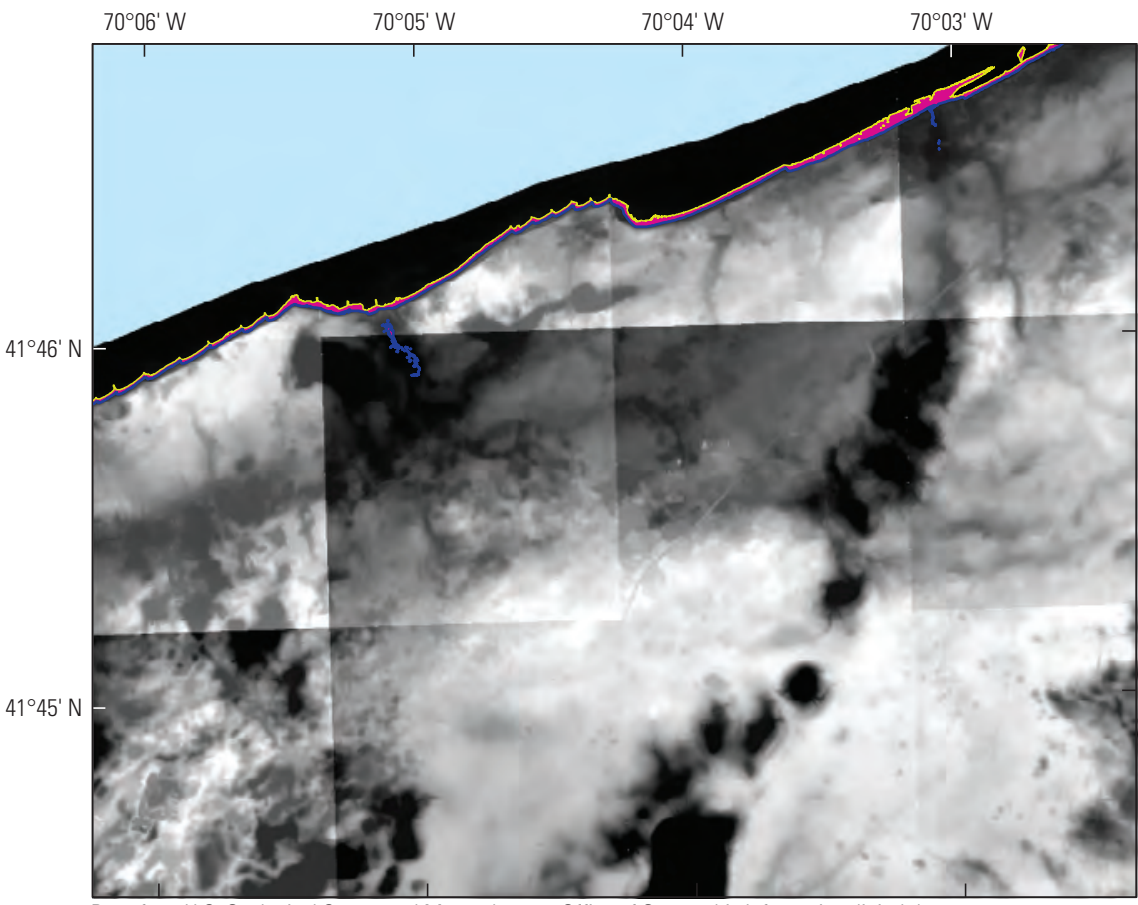

EXPLANATION

Land surface altitude, in feet above North American Vertical Datum of 1988

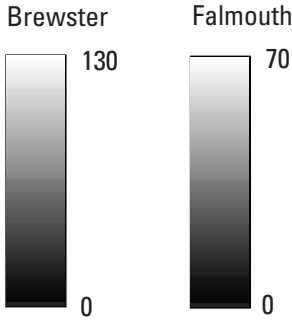

\section{B. Falmouth}
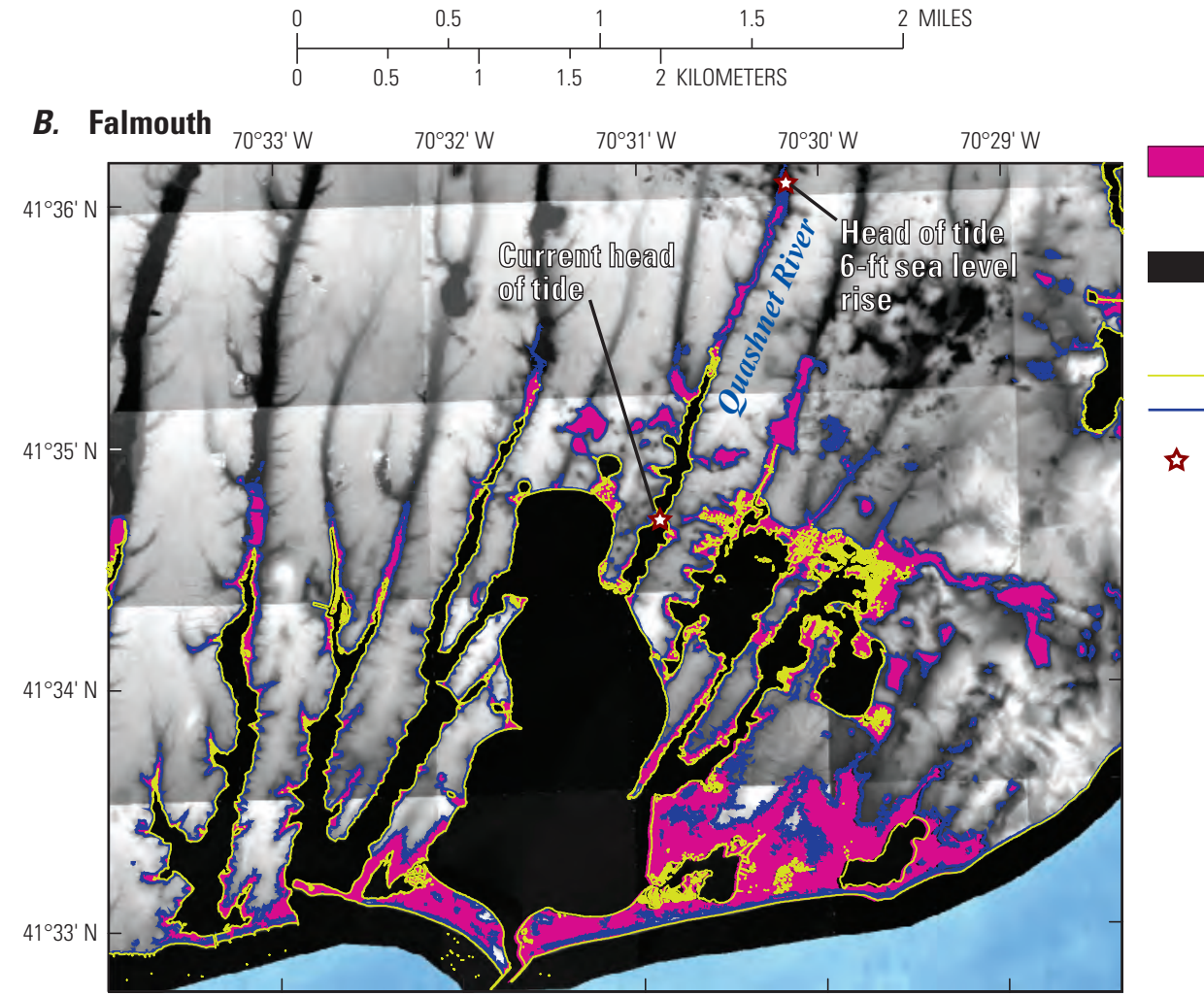

Static sea-water inundation when sea level rises 6 feet above sea level in 2011

Saltwater, no data

\section{Coastline geometry}

Sea level in 2011

Sea level 6 feet above 2011

Head of tide

Base from U.S. Geological Survey and Massachusetts Office of Geographic Information digital data

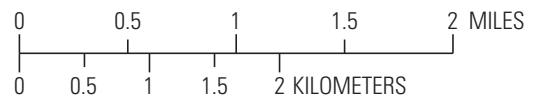

Figure 7. Coastline geometries estimated from 1-meter light detection and ranging (lidar) data for sea level in 2011 and 6 feet above sea level in 2011 and for areas of potential seawater inundation in $A$, Brewster and B, Falmouth on Cape Cod, Massachusetts. Location of areas shown in figure 5. 
In areas along the southern shore of Cape Cod, primarily in low-lying coastal areas and along estuaries and tidal rivers, coastline geometry changes considerably, showing extensive areas of potential seawater inundation with increasing sea levels. Seawater inundation near Waquoit Bay at Falmouth, Mass., in the southwestern part of the Sagamore flow lens (fig. $7 B$ ) occurs as areally extensive seawater inundation near beaches and low-lying coastal areas and as landward migration of the head of the tide of freshwater rivers. As an example, the head of the tide of the Quashnet River, the largest freshwater stream on Cape Cod, migrated landward by about $4,370 \mathrm{ft}$ when sea level was modeled to increase by $6 \mathrm{ft}$ from the 2011 sea level.

This approach assumes coastal landforms are static and does not account for coastal processes; this is often referred to as the "bathtub" assumption. Erosion and deposition and coastal-marsh accretion likely will alter coastal landforms very close to the coast, such as barrier beaches, coastal bluffs, and salt marshes. Salt-marsh accretion rates in the late Holocene were on the order of about 0.75 foot per century (Shaw and Ceman, 1999; Chmura and others, 2001), which would be an additional $0.67 \mathrm{ft}$ between 2011 and 2100 . Accretion rates generally are small, compared with rates of sea-level rise used in this analysis, on the order of 2 to $6 \mathrm{ft}$ by 2100 , and were not considered when delineating the coastal geometries.

Erosion and deposition from marine and aeolian processes can greatly alter, often catastrophically, coastal landforms over small time scales. Barrier beaches, bars, and spits such as South Beach and Sandy Neck (fig. 5), are particularly susceptible to these processes and can be considered dynamic landforms (Lentz and others, 2014). The delineation of future coastline geometries and estimates of seawater inundation may be locally inaccurate in these dynamic near-coastal areas. As an example, South Beach in Chatham, Mass., was extensively breached on April 16, 2007, by storm-driven tidal flooding, resulting in a coastal geometry that differs considerably from that observed in aerial photographs from 2005 (fig. 8A). Other differences in landforms between aerial photographs from 2005 and lidar data from 2011 were observed at several locations along barrier beaches, bars, and spits. It is likely that estimating coastal geometries arising from sea-level rise over decadal time scales in these dynamic coastal areas is subject to greater uncertainty than estimates in more stable coastal areas. A sea level $6 \mathrm{ft}$ above the sea level in 2011 in the same area results in a narrowing of the barrier island and inundation of salt marshes, but the nearby mainland has a steep topography, and the coastal geometry changes very little at sea levels greater than those in 2011 (fig. 8A). Coastal processes can alter landforms, particularly in dynamic settings, but as of 2015 there were insufficient data available to predict these effects across the study area at the required spatial extent and resolution to inform a regional analysis of sea-level rise effects.

Although the assumption of static landforms may not be valid in some dynamic coastal areas, it is not considered a significant limitation to this depth-to-water analysis for several reasons: these dynamic coastal areas comprise a very small part of the region's land mass (Sandy Neck, Nauset Beach, and locales along the southern shore), erosion and seawater inundation are far greater threats to these areas than is longterm groundwater inundation, and most of these areas are undeveloped or have limited infrastructure.

Back-barrier marshes and ponds are fresh or brackish waters that are at or below sea level and are separated from the sea by barrier bars or have constricted connections to the sea. They occur in a number of locations on Cape Cod, and higher sea levels from those in 2011 likely will result in the formation of additional back-barrier water features (fig. 5). Coastal erosion and breaching of the barrier bars could greatly alter the hydrologic setting of these features and the response of the local groundwater flow system to sea-level rise. These features often extend inland and can be near developed areas, particularly along the southern shore. The hydrologic characteristics of barrier bars could affect an analysis of sea-level rise and depth to water. Stewarts Creek along the south-central coast (fig. 5) is an example of a back-barrier marsh (fig. 8). The altitude of the marsh ranges from 0.1 to about $1.5 \mathrm{ft}$ and is separated from Nantucket Sound by a barrier bar with a limited hydraulic connection though a culvert; it is defined as a freshwater feature for the sea level in 2011 (fig. 8B). Much of the lower part of the creek was modelled to be below sea level following a 6-ft sea-level rise, but a narrow barrier bar between the creek and Nantucket Sound still remained (fig. $8 B$ ). The future hydrologic setting of the creek is a function of changes in the barrier bar, resulting from coastal erosion or deposition. The creek could remain a freshwater or brackish water feature if the bar remains or aggrades or could become a saltwater estuary if the bar is removed or breached. The change in hydrologic setting would affect the local position of the freshwater/saltwater interface and water-table altitudes and the response of the system to sea-level rise. The assumption of static landforms may not be valid in these cases, and analysis of depths to water could be affected.

\section{Hydrologic Data}

Observations of water levels and streamflow obtained from several sites-38 long-term wells, 563 partialrecord wells, 26 pond stages, 2 continuous streamgages, and 48 partial-record streamflow sites - were used in the calibration of the groundwater-flow model (fig. 9A). Precipitation and, as a result, water levels and streamflows on Cape Cod vary greatly over multiyear and monthly times scales (fig. 9B). The effect of rising sea levels on the groundwater system is simulated over decadal time scales; to this end, long-term average hydrologic conditions, derived from the large volume of hydrologic data, were estimated and used in calibration of the new steady-state numerical model. Data from different sources and with different periods of record were grouped according to their assumed reliability as observations of steady-state hydrologic conditions.

Water-level observations were compiled from a number of sources, including the USGS, the CCC, the APCC, local 
$\boldsymbol{A}$ $69^{\circ} 57^{\prime} \mathrm{W}$

$69^{\circ} 56^{\prime} \mathrm{W}$

$69^{\circ} 55^{\prime} \mathrm{W}$
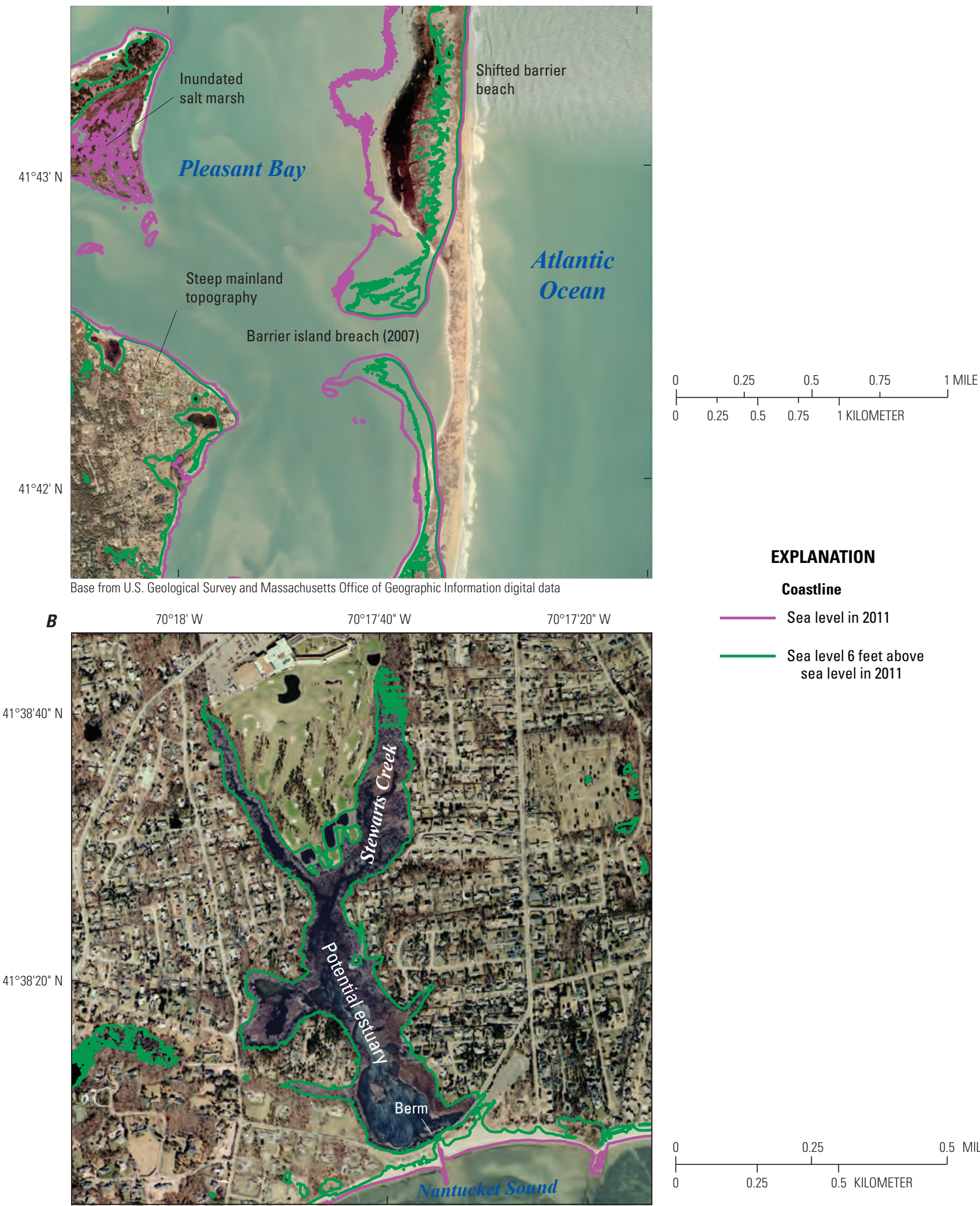

Base from U.S. Geological Survey and Massachusetts Office of Geographic Information digital data

\section{EXPLANATION}

\section{Coastline}

Sea level in 2011

Sea level 6 feet above sea level in 2011

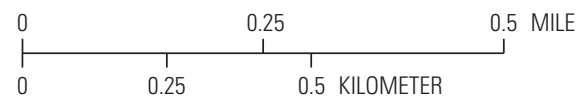

Base from U.S. Geological Survey and Massachusetts Office of Geographic Information digital data

Figure 8. Coastal geometry estimated from 1-meter light detection and ranging (lidar) data and examples where assumptions of static coastal landforms may not be valid; $A$, a barrier-island breach in Chatham, and $B$, a potential back-barrier coastal pond at Stewarts Creek in Barnstable on Cape Cod, Massachusetts. Location of areas shown in figure 5. 


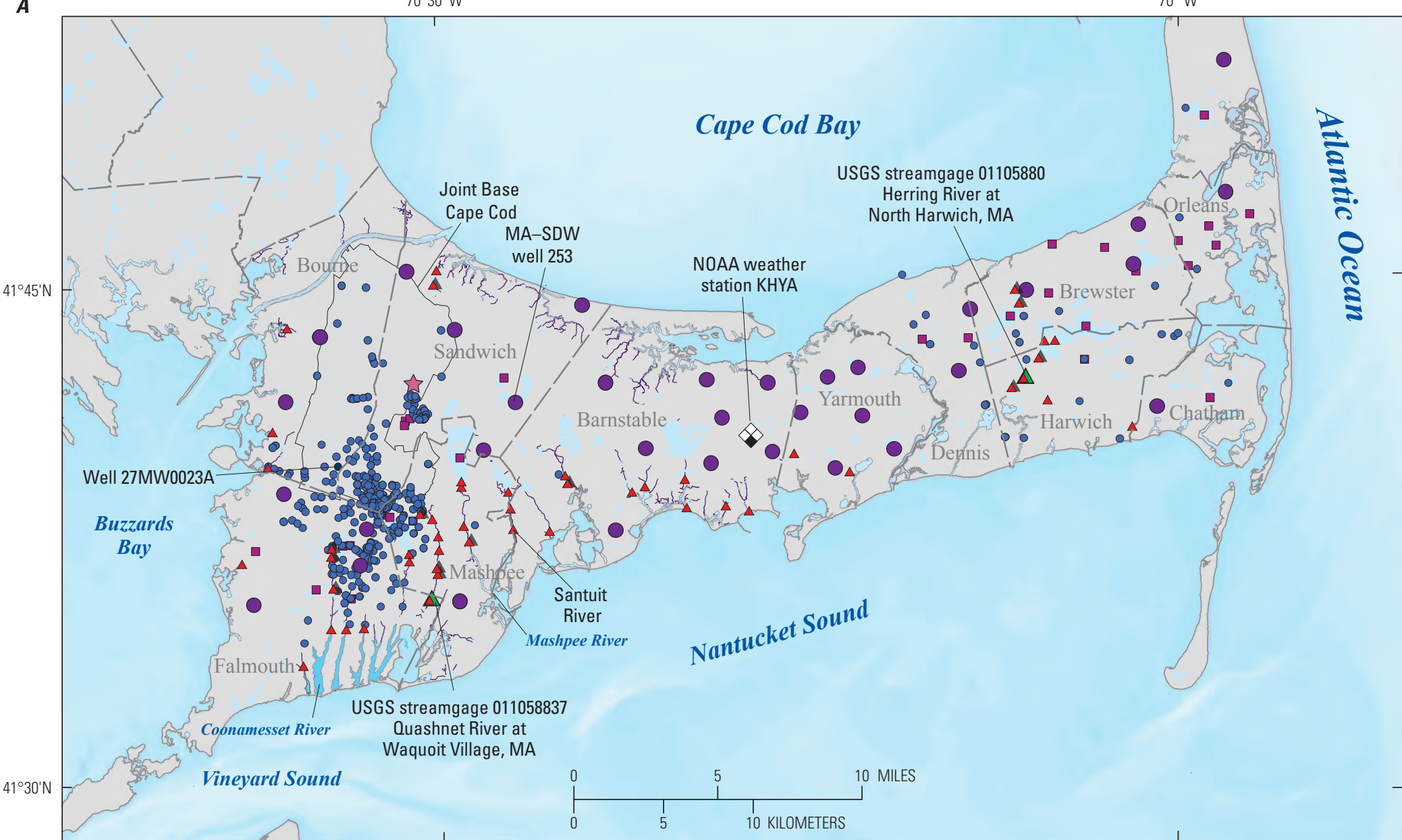

Base from U.S. Geological Survey and Massachusetts Office of Geographic Information digital data

\section{EXPLANATION}

NOAA weather station

USGS groundwater monitoring site

- Long-term index well

- Continuous record well

- USGS pond water level monitoring site
USGS streamflow monitoring site

$\triangle \quad$ Long-term continuous record site

A Major stream

$\Delta \quad$ Minor stream

\section{Estimated location of highest water}

table altitude (water table

$$
\text { mound) }
$$

Figure 9. A, Locations of the National Oceanic and Atmospheric Administration (NOAA) weather station (precipitation gage) at Hyannis, Barnstable Municipal—Boardman Airport (KHYA) in Hyannis, Massachusetts, groundwater monitoring wells, and streamflow sites on Cape Cod, Mass., and B, graph showing precipitation at the KHYA precipitation gage and streamflow from long-term well MA-SDW 253 in Sandwich County, Mass., and U.S. Geological Survey (USGS) continuous-record streamgage 011058837 Quashnet River at Waquoit Village, Mass. 


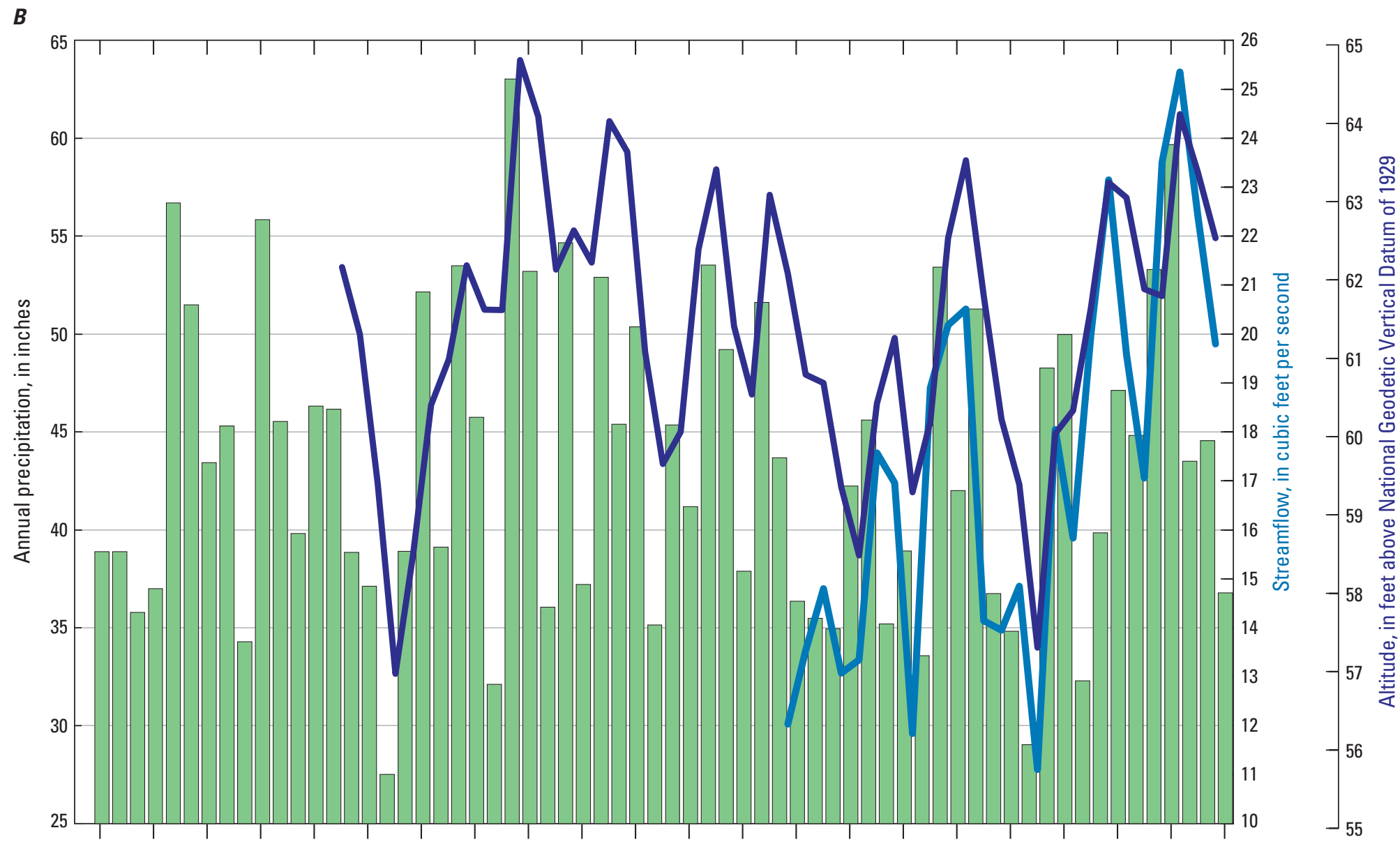

$\begin{array}{llllllllllllllllllllll}1949 & 1952 & 1955 & 1958 & 1961 & 1964 & 1967 & 1970 & 1973 & 1976 & 1979 & 1982 & 1985 & 1988 & 1991 & 1994 & 1997 & 2000 & 2003 & 2006 & 2019 & 2012\end{array}$

Year

\section{EXPLANATION}

\section{Precipitation at NOAA weather station KHYA}

Figure 9. A, Locations of the National 0 ceanic and Atmospheric Administration (NOAA) weather station (precipitation gage) at Hyannis, Barnstable Municipal-Boardman Airport (KHYA) in Hyannis, Massachusetts, groundwater monitoring wells, and streamflow sites on Cape Cod, Mass., and

$B$, graph showing precipitation at the KHYA precipitation gage and streamflow from long-term well MA-SDW 253 in Sandwich County, Mass., and U.S

Geological Survey (USGS) continuous-record streamgage 011058837 Quashnet River at Waquoit Village, Mass.-Continued 
water suppliers, and U.S. Department of Defense contractors on Joint Base Cape Cod (JBCC; formerly the Massachusetts Military Reservation). A total of 5,626 water-level measurements (monitoring wells and ponds) were compiled from various sources; many of the monitoring wells are in or near the JBCC on the Sagamore flow lens. The altitudes of the well screens vary, and the screen altitudes represent most vertical parts of the aquifer. Kettle ponds on Cape Cod are surface expressions of the water table; water levels have been measured at 109 ponds on the Sagamore and Monomoy flow lenses and were included in the calibration.

This analysis assumes steady-state conditions; calibration of the numerical model requires observations that generally represent long-term average hydrologic conditions. A total of 38 wells within the study area have been measured monthly by the Cape Cod Commission and have monthly or continuous measurements that extend back more than 30 years (referred to as "long-term wells"); an additional 2,478 wells have intermittent measurements that extend back more than 10 years (referred to as "partial-record sites"). Water-level measurements for each partial-record site were compared with measurements at the long-term wells during the corresponding period of record. The mean water level in a partial-record well was included as a calibration target if the same partial period at each long-term well had a mean that was within 20 percent of one standard deviation of the mean for the entire period of record for the long-term well. As an example, long-term well MA-SDW 253 has a mean water level of $61.3 \mathrm{ft}$ and a standard deviation of $1.9 \mathrm{ft}$ over its 50-year period of record (1963-2012); the mean water level for partial-record well 27MW0023A over its 21-year period of record (1998-2008) is $55.52 \mathrm{ft}$ (fig. 10A). The mean water level in well MA-SDW 253 during the partial-record period of well 27MW0023A is $61.05 \mathrm{ft}$, which differs from the full-record mean by $0.24 \mathrm{ft}$, or about 12.6 percent of one standard deviation. The mean departure from the average of all 38 long-term wells for the same period is 14.9 percent of one standard deviation; therefore, the mean water level at site 27MW0023A is considered near average, and the observation is a suitable steady-state calibration target. This process was used to identify an additional 563 partial-record wells and 26 ponds whose records were suitable steady-state water-level observations (fig. $9 A$ ).

Sources of streamflow data include the USGS, the MEP, and data collected as part of remedial investigations near the JBCC. The data included streamflow from two continuous streamflow sites: the Quashnet River on the Sagamore flow lens (period of record from 1988 to present) and the Herring River on the Monomoy flow lens (period of record from 1966 to 1988; fig. 9). Data also were compiled from partial-record sites. The suitability of mean partial-record streamflows for use as observations of steady-state conditions was determined by comparison with the long-term record at the Quashnet River, which had a mean of 17.41 cubic feet per second $\left(\mathrm{ft}^{3} / \mathrm{s}\right)$ and a standard deviation of $5.7 \mathrm{ft}^{3} / \mathrm{s}$ during its 14-year period of record (fig. 10B). The mean streamflow at a partial record site is assumed to be suitable as a steady-state calibration target if the mean streamflow at the Quashnet River during the partial-record period differed by less than 30 percent of one standard deviation of the full Quashnet River record (or about $1.7 \mathrm{ft}^{3} / \mathrm{s}$ ). Many of the measurements were collected in May 2002 as part of synoptic measurements, when hydrologic conditions were determined to be near average (Walter and Whealan, 2005). In addition, average long-term streamflow for sites with greater than 5 nonzero measurements were estimated by correlating the partial records to the full period of record for the Quashnet River. The Streamflow RecordExtension Facilitator (SREF) program (Granato, 2009) was used to extend limited data from 10 partial-record sites, including the Backus River, Coonamesset River, and Mill Creek. The SREF program implements the maintenance of variance extension methods (MOVE.1 and MOVE.3; Hirsch, 1982). A total of 48 partial record streamflow sites were determined to be suitable for inclusion as observations of long-term streamflow.

A regional groundwater divide in the northern part of the Sagamore flow lens (fig. $1 \mathrm{~A}$ ) represents the highest water table altitude in the aquifer, from which hydraulic gradients are radially outward. A number of contaminant plumes emanating from surrounding sources on the JBCC define a radial pattern of advective transport from which the approximate location of the divide can be inferred (Environmental Chemical Corporation, 2007). The inferred location of the divide is included in the inverse calibration regression as an observation. The residual is the distance, in feet, between the observed and simulated coordinates of the divide. The simulated coordinates of the divide are calculated by polynomial interpolation of the 26 highest simulated heads within a 1 -ft subgrid; the 1 -ft grid allows for the divide location to approximate a continuous function during the model calibration.

\section{Climate and Land Use Data}

The climate of Cape Cod is typified by warm, often humid, summers and cold winters (Peel and others, 2007) and is moderated by the proximity to ocean waters as compared with interior parts of the northeastern United States. Precipitation at the KHYA monitoring site in Hyannis averaged 43.4 inches per year (in/yr; 1,102.36 mm/yr) between 1949 and 2013 (fig. 9B). Recharge from precipitation is the sole source of water to the Cape Cod aquifer and has been estimated using several methods, including groundwater model calibration, water balance approaches using various methods to estimate evapotranspiration, and age dating techniques (LeBlanc and others, 1986; Barlow and Hess, 1993; Solomon and others, 1995; Masterson and others, 1997b; Massey and others, 2006).

Aquifer recharge is a function of climatological conditions (precipitation and temperature) and landscape characteristics (land use, soil properties, and vegetation land use). Variations in these factors affect the rates and distribution 


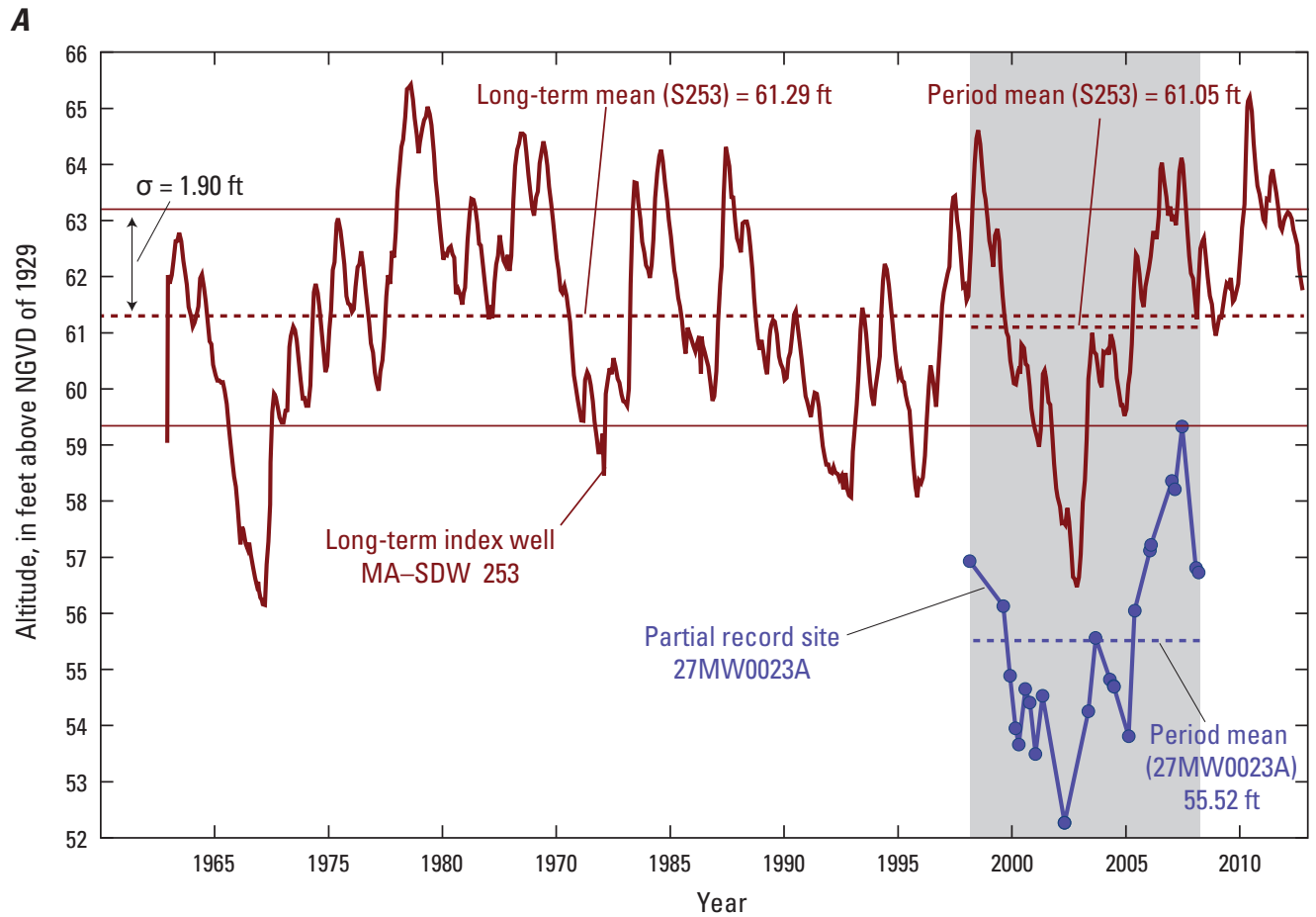

B

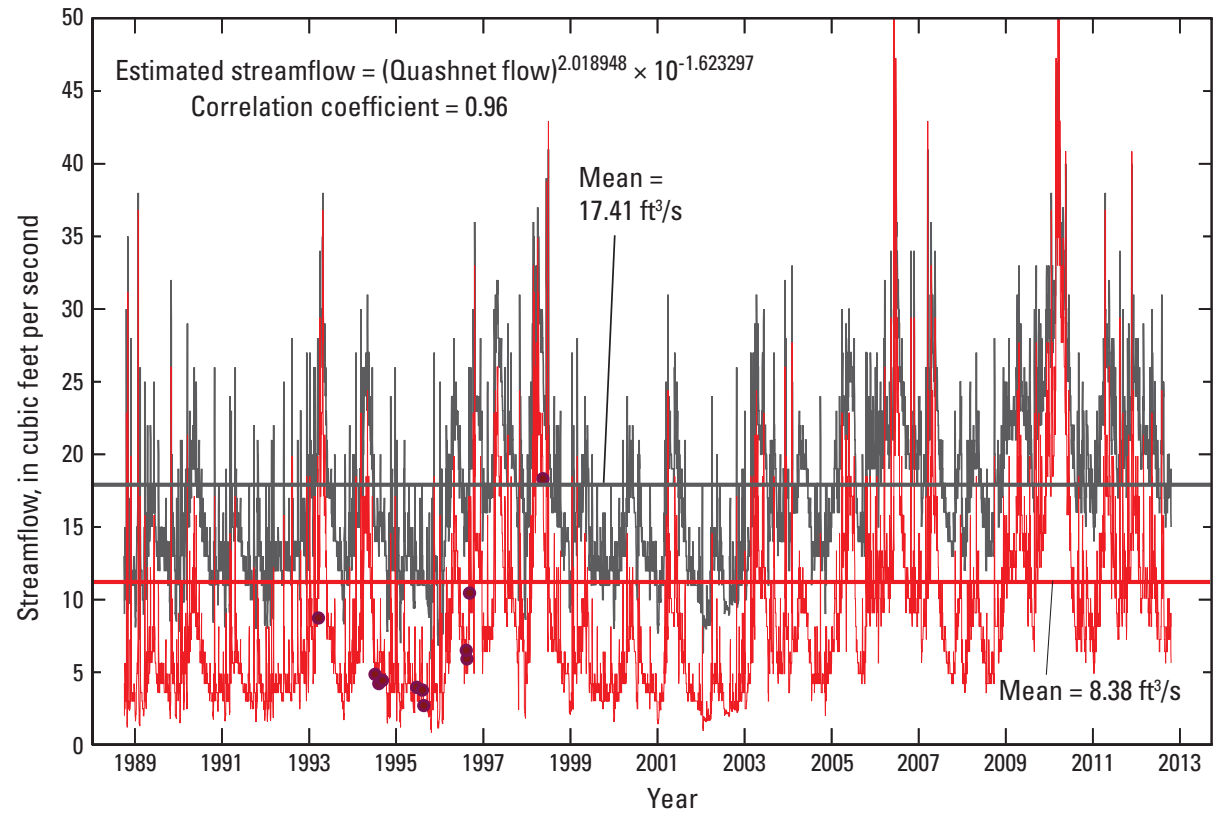

EXPLANATION

- Mean daily streamflow at USGS streamgage 011058837, Quashnet River at Waquoit Village, MA

Streamflow at USGS streamgage 0110588340 Santuit River at Old Kings Hwy

- Estimated mean daily streamflow at USGS streamgage 0110588340 Santuit River at Old Kings Hwy

Figure 10. A, Water table altitude at U.S. Geological Survey (USGS) long-term monitoring well MA-SDW 253 and partial record monitoring well 27MW0023Al and $B$, maintenance of variance extension (MOVE.1) analysis for USGS partial-record streamgage 0100588340 Santuit River at Old Kings Highway. $\sigma$, standard deviation; ft, foot; $\mathrm{ft}^{3} / \mathrm{s}$, cubic foot per second. 
of recharge. The Soil-Water Balance (SWB) model (Westenbroek and others, 2010) accounts for processes that take place as water moves through unsaturated soils and sediments to the water table and is based on a modified version of the Thornthwaite-Mather methodology (Thornthwaite and Mather, 1957). The method incorporates land slope, soil properties, and climate data and produces a spatially distributed recharge grid using commonly available geographic information system (GIS) data layers in combination with tabular climate data.

The SWB model was used to estimate the spatial distribution of recharge on Cape Cod averaged from 1949 to 2012. Daily precipitation and temperature values at the KHYA weather station in Hyannis were compiled for 1949 to 2012 (National Oceanic and Atmospheric Administration, 2012) as part of that effort. A variety of spatial data - distribution of 13 classes of 2005 land use for Cape Cod (Massachusetts Office of Geographic Information, 2012), NRCS hydrologic soil groups classified by the ability of water to enter and pass through the soil (U.S. Department of Agriculture, Natural Conservation Service, 2013), and NRCS water capacity (a measure of water held in soil that is available for use by plants; U.S. Department of Agriculture, Natural Conservation Service, 1998) - also were compiled and used with climate data to estimate the spatial distribution of recharge by use of the SWB model. The SWB-estimated recharge rate on the Sagamore and Monomoy flow lenses averaged from 1949 to 2012 was about $19.3 \mathrm{in} / \mathrm{yr}(490.22 \mathrm{~mm} / \mathrm{yr})$ and varied from $0 \mathrm{in} / \mathrm{yr}(0 \mathrm{~mm} / \mathrm{yr})$ over surface-water bodies and large impermeable surfaces to more than $23 \mathrm{in} / \mathrm{yr}(584.2 \mathrm{~mm} / \mathrm{yr})$ over the moraine areas and southern parts of the outwash plains (fig. 11). The recharge rate onto surface waters was specified to be $16 \mathrm{in} / \mathrm{yr}(406.4 \mathrm{~mm} / \mathrm{yr})$, generally representing the difference between precipitation and pan evaporation. The SWBestimated recharge values generally were lower than previously published recharge estimates for the study area, although the SWB method provides spatial variability that can be scaled to expected mean values as part of model calibration.

\section{Simulation of the Freshwater/Saltwater Interface}

Regional models have been previously published for a number of coastal aquifers in southeastern Massachusetts (fig. 12), including separate models of the Sagamore and Monomoy flow lenses on Cape Cod (Walter and Whealan, 2005), a single model of the other four Cape Cod flow lenses (Lower Cape Cod aquifer; Masterson, 2004), and a single model for the Plymouth-Carver aquifer on the mainland adjacent to Cape Cod (Masterson and others, 2009).The extents of models developed to facilitate analysis of sealevel rise (fig. 12) include parts of all four existing models of southeastern Massachusetts: models of the Sagamore and Monomoy flow lenses (Walter and Whealan, 2005) a model of the Lower Cape Cod aquifer system (Masterson, 2004), and a model of the Plymouth-Carver aquifer (Masterson and others, 2009). These models provide information relevant to the development of the new groundwater-flow model, including initial aquifer properties, reasonable approximations of current water table altitudes, and the geometry of hydrologic boundaries. Two separate but implicitly linked numerical models that use the USGS numerical modeling code MODFLOW (Harbaugh, 2005) and include the Sagamore and Monomoy flow lenses were used for this analysis: a 2D model capable of simulating the 3D position of the freshwater/saltwater interface (referred to in this report as the coastal model) and a 3D groundwater-flow model capable of simulating the hydrologic system and its response to sealevel rise (referred to in this report as the groundwater-flow model). The two models are implicitly linked by a common freshwater/saltwater interface. The 2D coastal model was not calibrated, but since aquifer properties, recharge and hydraulic stresses were derived from previously calibrated model, it is assumed that the simulated fresh/saltwater interface is considered a reasonable regional-scale representation of the actual interface.

The Cape Cod aquifer is underlain in coastal areas by a dynamic freshwater/saltwater interface that represents a hydraulic balance between fresh groundwater and dense saline groundwater. The interface generally is observed to be sharp (LeBlanc and others, 1986) and would be expected to change in response to sea-level rise. The coastal model used in this analysis was developed as a test case for the SWI2 Package (Bakker and others, 2013): a MODFLOW package capable of simulating a dynamic interface position. SWI2 allows threedimensional vertically integrated variable-density groundwater flow with MODFLOW-2005 through the addition of pseudosource terms to the groundwater flow equation. Vertical and horizontal movement of defined density surface is calculated separately using a combination of fluxes calculated through solution of the groundwater flow equation and a simple tip and toe tracking algorithm (Bakker and others, 2013).

The coastal model represents both the Sagamore and Monomoy flow lenses and extends from west of the Cape Cod Canal to beyond Town Cove to the east (fig. 13). The model grid consists of 1 layer, 1,384 rows, and 2,272 columns and has a uniform horizontal discretization of $100 \mathrm{ft}$. The total simulation time was 100 years discretized into 7,300 time steps with a uniform length 5 days. A uniform porosity of 0.2 was used in the simulation. Hydraulic conductivity values were derived from the previously published calibrated regional models encompassed by the model (fig. 12; Masterson, 2004; Walter and Whealan, 2005; Masterson and others, 2009). The hydraulic conductivities in each cell are equivalent to the thickness-averaged hydraulic conductivity of the corresponding layers in the existing 3D models, resulting in an equivalent transmissivity. Recharge, pumping, and return-flow stresses also were derived from values in previously calibrated models and, in the Sagamore and Monomoy flow lenses, represented pumping rates in 2003 (Walter and Whealan, 2005); these were similar to the 2010 pumping rates simulated in the 3D groundwater flow model. Pumping stresses generally are a 


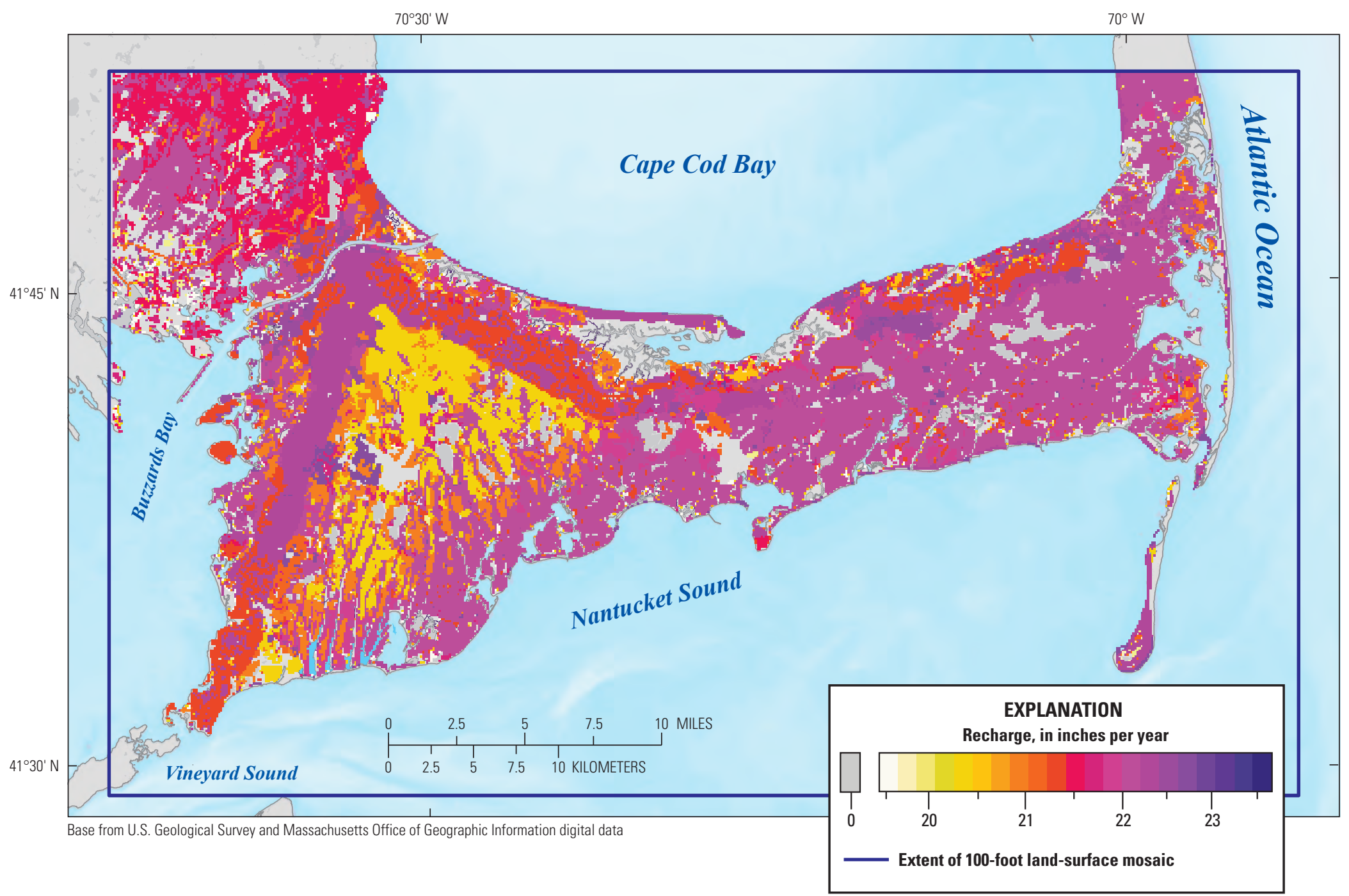

Figure 11. Annual average recharge rates on Cape Cod, Massachusetts, estimated using the Soil-Water Balance model (Westenbroek and others, 2010). 


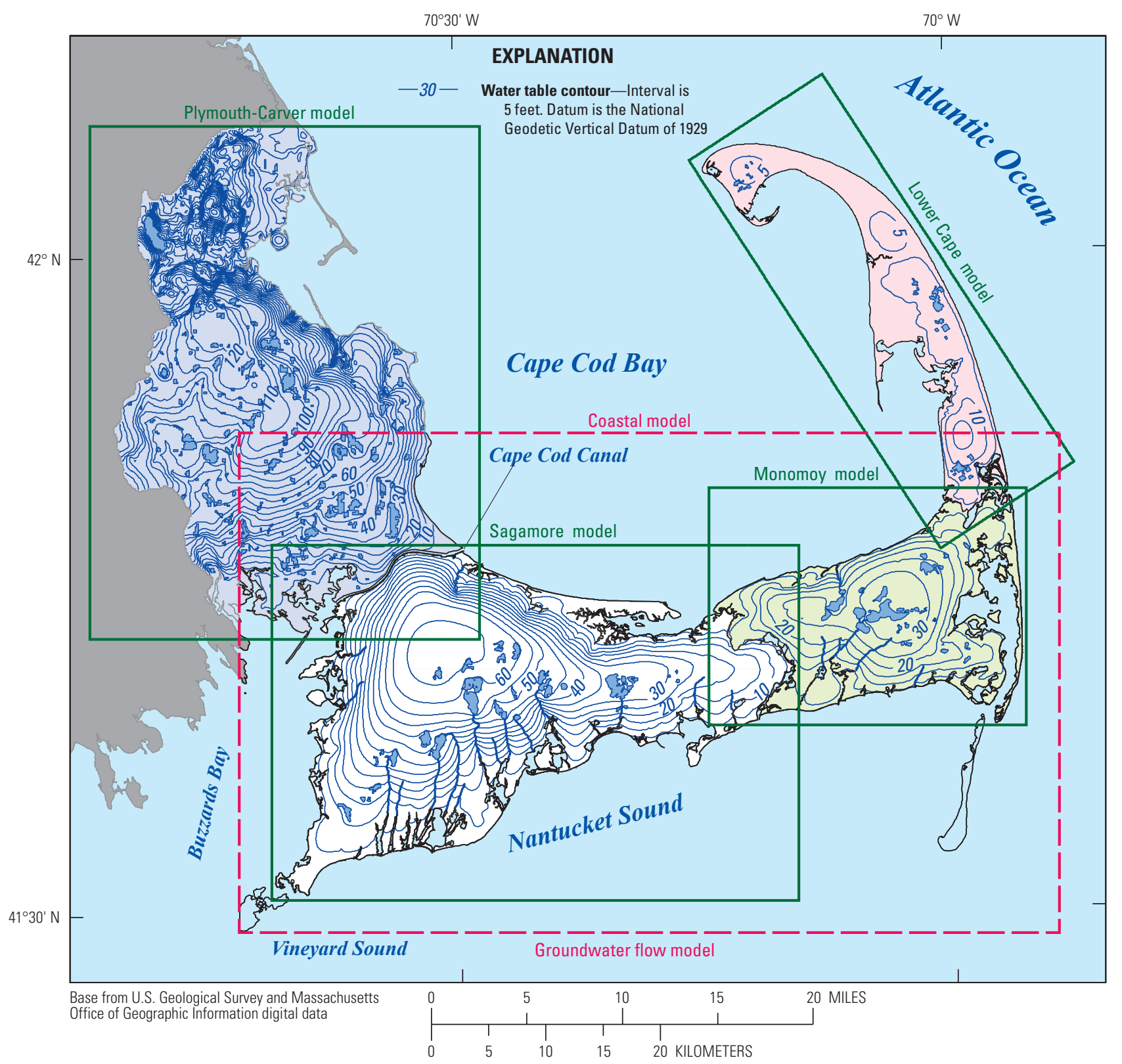

Figure 12. Extent of previously published models of coastal aquifers for southeastern Massachusetts and new model for central and western Cape Cod, Mass. JBCC, Joint Base Cape Cod.

small component of the hydrologic budget - about 5 percentso small differences in simulated pumping in the $2 \mathrm{D}$ and $3 \mathrm{D}$ models are not likely to have a large effect on the positon of the fresh/saltwater interface.

The bottom of the model is a seamless bedrock surface interpolated from data collected on western Cape Cod (Fairchild and others, 2012) and, to the east, a bedrock surface derived from unpublished data (Byron D. Stone, U.S. Geological Survey, written commun., 1997) previously used in regional models of the Sagamore and Monomoy flow lenses (Walter and Whealan, 2005). The top of the model is land surface derived from 10-m digital elevation model data and 30 -m bathymetry in offshore areas. Estuaries and open coastal waters were represented as head-dependent flux boundaries by use of the General Head Boundary package for MODFLOW (McDonald and Harbaugh, 1988); freshwater-equivalent heads calculated from bathymetry were specified at these boundaries. Streams, salt marshes, and surface-drained wetlands were represented by use of the Drain package for MODFLOW (McDonald and Harbaugh, 1988). The simulated interface position was shown to be sensitive to leakances specified at coastal boundaries; leakances were adjusted by trial and error 


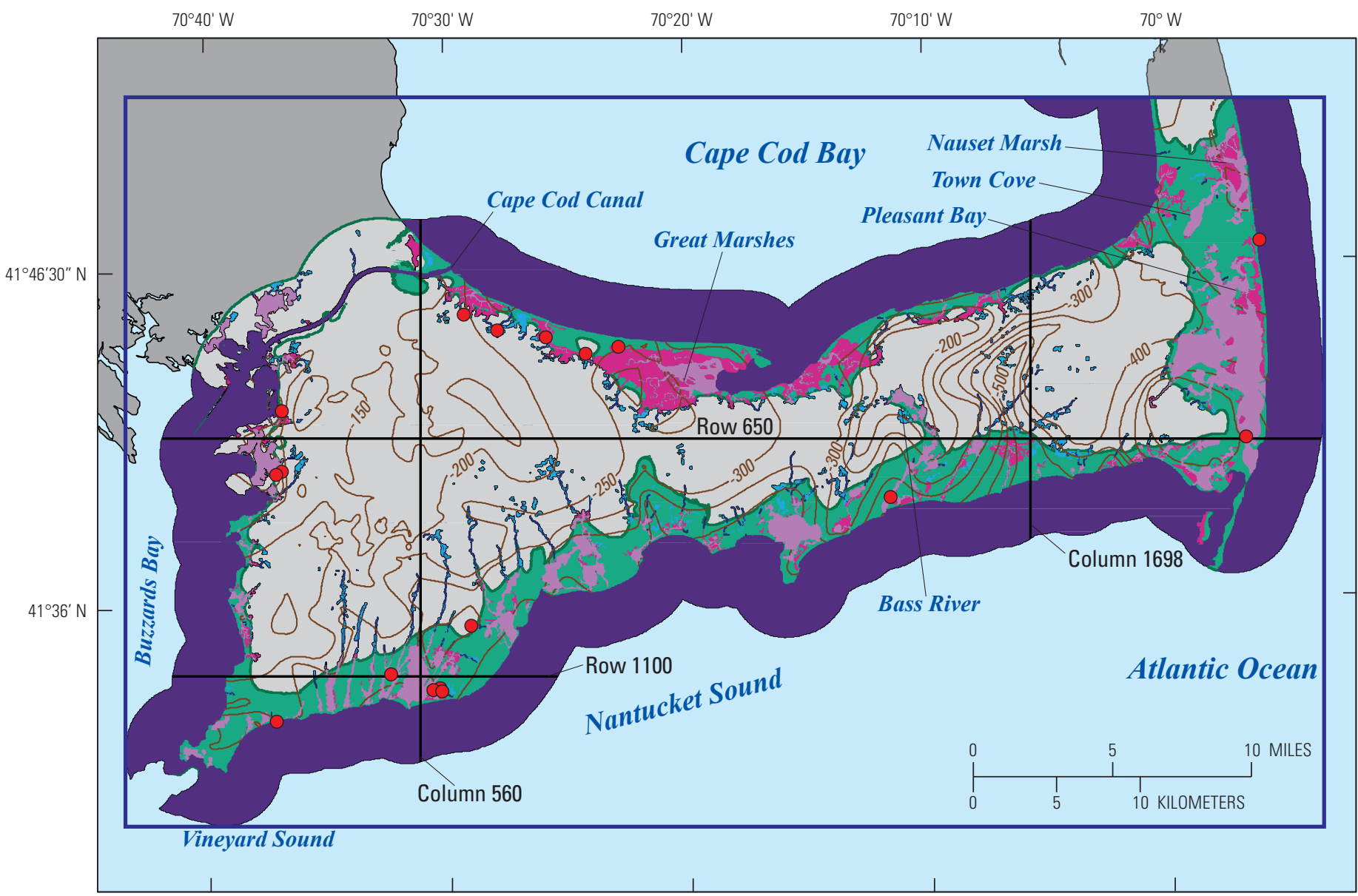

Base from U.S. Geological Survey and Massachusetts Office of Geographic Information digital data

\section{EXPLANATION}
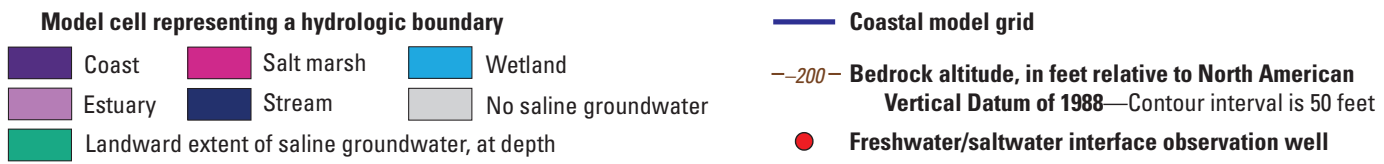

Figure 13. The extent of a two-dimensional coastal model, hydrologic boundaries, bedrock altitudes, and areas of the aquifer underlain by saline groundwater in 2011 as simulated by the model for central and western Cape Cod, Massachusetts.

until a reasonable fit to the observed interface altitude was reached at 19 locations near the JBCC and other locations on central and western Cape Cod (LeBlanc and others, 1986).

Because of high recharge rates, shallow bedrock (100 to $300 \mathrm{ft}$ below land surface), and high water table altitudes (more than $60 \mathrm{ft}$ ), most fresh groundwater in the Sagamore and Monomoy flow lenses is underlain by bedrock (fig. 14). Bedrock altitudes are much shallower than the theoretical position of the freshwater/saltwater interface based on a density ratio of 1:40 and a hydrostatic balance between freshwater and saltwater (Drabbe and Ghyben, 1888; Herzberg, 1901). This hydraulic condition likely would limit the potential for lateral saltwater intrusion into the aquifer. Fresh groundwater is underlain by saline groundwater in coastal areas, particularly along the southern and eastern shores (fig. 14). Broad areas of the aquifer are underlain by an interface near large coastal water bodies, such as Great Marshes, Bass River, Pleasant Bay, and Nauset Marsh (figs. 13 and 14). Nantucket Sound has a complex coastal morphology with numerous freshwater streams and tidal rivers that extend inland; the discharge of groundwater into these features results in a shallow freshwater/saltwater interface (fig. 14) and the presence of saline groundwater at depth beneath freshwater as far inland from the coast as 3 miles (fig. 13).

The 2D coastal model was modified for use in this analysis by altering hydrologic boundaries to better represent the detailed coastal geometry estimated from 1-m lidar data. A number of changes to the boundaries also were made by 


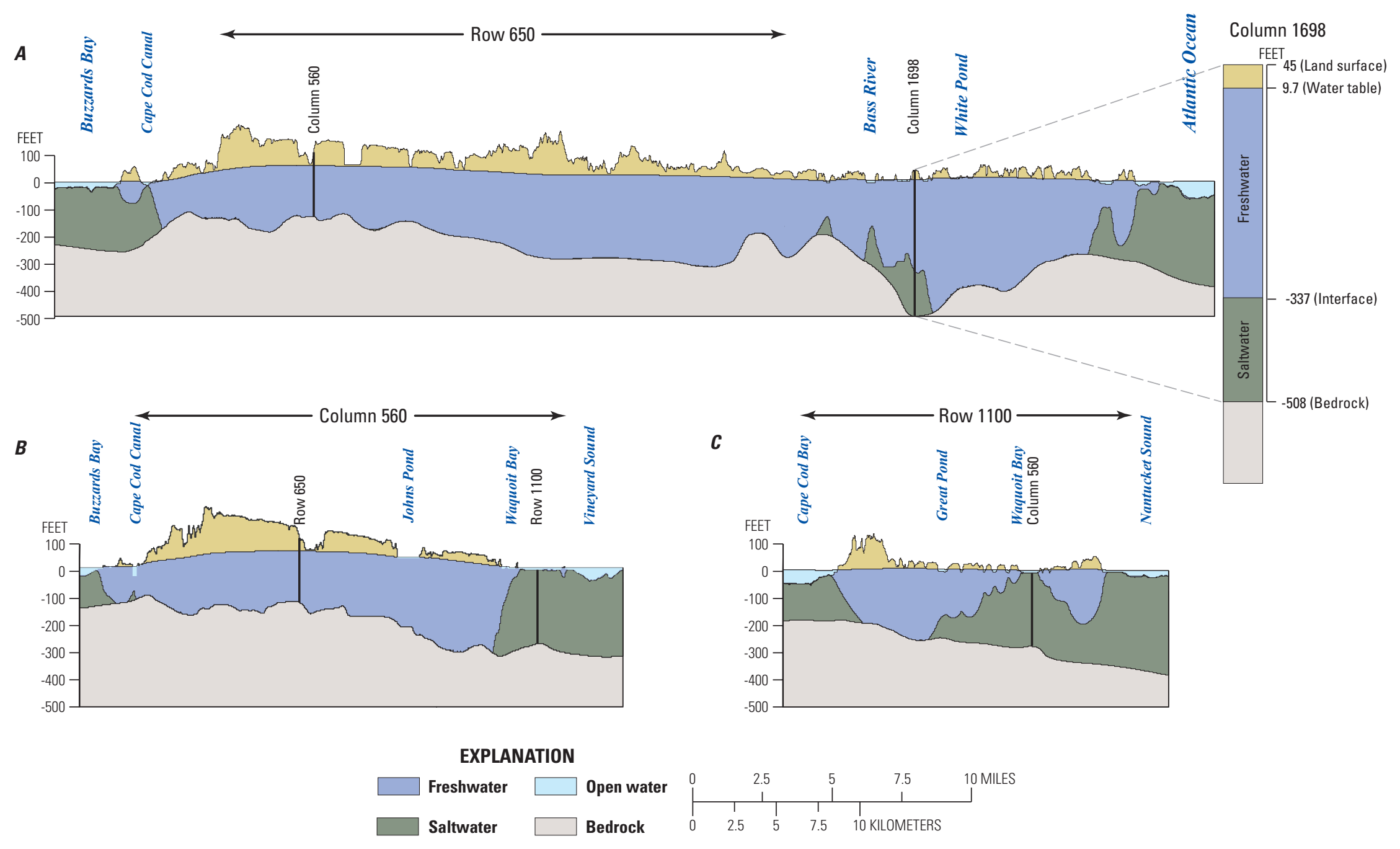

Figure 14. Simulated altitude of the freshwater/saltwater interface in central and western Cape Cod, Massachusetts, for sea level in 2011 along $A$ and $B$, east-west sections and $C$, a north-south section. Altitude is relative to North American Vertical Datum of 1988. 
step-wise visual inspection of georeferenced aerial photographs to identify and correct anomalies. Specified boundary heads were corrected for wetlands and streams using lidar data; lidar spatially averaged over the $100-\mathrm{ft}$ model cell was specified in wetlands, and minimum values within the $100-\mathrm{ft}$ model cell were specified in streams. The position of the freshwater/saltwater interface was calculated using these modified hydrologic boundaries and incorporated into the 3D groundwater-flow model as a no-flow boundary. Similar modifications were made using coastal geometries for sea levels 2, 4, and $6 \mathrm{ft}$ above the sea level in 2011. Boundary heads in coastal waters for each of the future sea levels were specified as the freshwater-equivalent head calculated using the new sea level and bathymetry in offshore areas or spatially averaged lidar in newly submerged areas. The interface position for each sea level was simulated and incorporated into the corresponding version of the groundwater-flow model to simulate the water table response to the each future sea level.

\section{Simulation of the Hydrologic System in 2011}

A 3D numerical steady-state groundwater-flow model of the Sagamore and Monomoy flow lenses, the groundwaterflow model, was developed that incorporates data from existing regional models of coastal aquifer systems in southeastern Massachusetts by using the finite-difference modeling program MODFLOW-2005 (Harbaugh, 2005). The model is capable of simulating water levels and streamflows as well as the response of the hydrologic system to natural and anthropogenic stresses, including sea-level rise. Finitedifference models represent an aquifer system as discrete, interconnected blocks (or cells) of aquifer, with intrinsic properties and boundary conditions representing surface water features, wells, or recharge. The model output includes, for each model cell, head in the cell and flow terms between the cell and all neighboring cells. This information can be used to evaluate the effects of changing stresses, including sea-level rise, on water levels, streamflows, and hydraulic gradients.

\section{Model Design}

The model used in this analysis incorporates information from existing calibrated models of the Sagamore and Monomoy flow lenses (Walter and Whealan, 2005). These models use a diverse set of geophysical, hydrologic, lithologic, and water-quality data collected within the study area during the past 30 years. Two separate regional models of the Sagamore and Monomoy flow lenses (Walter and Whealan, 2005) had been developed to simulate the response of the hydrologic system to pumping and return flow under both steady-state and transient conditions; the models also had been used to develop recharge areas to wells and natural receptors (Walter and others, 2004). The models incorporated zonation based on a depositional model of Cape Cod (Masterson and others, 1997a); aquifer properties, boundary leakances, and recharge were adjusted by trial and error to match steady-state observations of heads and streamflows. The model developed as part of this effort builds on these existing models, includes more recent lithologic and geophysical data collected within and near the JBCC, and represents the first comprehensive model of the Sagamore and Monomoy flow lenses. The parameters of this latest model are detailed in the following sections.

\section{Model Grid and Boundaries}

The model grid extends from Cape Cod Canal to Town Cove and east to the Atlantic Ocean and consists of 346 rows, 568 columns, and 25 layers with a uniform horizontal discretization of $400 \mathrm{ft}$ (fig. 15A); there are a total 70,885 active cells in the top layer of the model. The grid is coincident with existing regional models of the Sagamore and Monomoy flow lenses (fig. 12) and has the same extent as and is coincident with the fine-scale, discretized grid of the coastal model (fig. 13). The top of the model is the land surface derived from lidar data and bathymetry in offshore areas (fig. 5) and is simulated as unconfined. The bottom of that layer was set to be an altitude $15 \mathrm{ft}$ below an initial approximation of the water table derived from existing regional models. Cells in layer 1 with thicknesses of less than $5 \mathrm{ft}$ following truncation by the freshwater/saltwater interface were specified as inactive to remove stranded offshore cells. Layers 2 through 18 were equally divided from the bottom of layer 1 and $200 \mathrm{ft}$ below NAVD 88 (fig. 15B and C). A smoothing algorithm was used to minimize large changes in model layer altitudes near surface water bodies; the algorithm iteratively lowered the cell bottoms until neighboring cells overlapped vertically by at least 50 percent. Layers 19 through 25 have uniform tops and bottoms and extend to the bottom of the aquifer; the tops of layers 19 through 25 are 200, 230, 260, $290,330,370$, and $420 \mathrm{ft}$ below NAVD 88, respectively. The bottom of the aquifer is defined as a composite of bedrock and the simulated freshwater/saltwater interface from the coastal model (fig. 15B).

Surface water features are represented as head-dependent flux boundaries (fig. 15A). Coastal water bodies, including estuaries and open coastal waters, are represented using the General Head Boundary (GHB) package for MODFLOW (McDonald and Harbaugh, 1988); salt marshes and fresh surface waters, which include streams, wetlands connected to streams, and pond outlets, are represented (fig. 15A) using the Drain (DRN) package for MODFLOW (Harbaugh and others, 2000). Coastal boundaries were determined using the coastal geometry as determined from lidar data from 2011. The boundaries were modified by visual inspection of aerial photographs to address anomalies and ensure consistency between simulated boundaries and actual conditions. Streams and wetland boundaries were determined by 1:24,000-scale hydrography followed by visual inspection of aerial photographs. Altitudes in saltwater boundaries were determined using freshwater-equivalent heads determined from bathymetric data. Boundary altitudes in saltwater and freshwater 
A

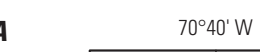
$70^{\circ} 40^{\prime} \mathrm{W}$

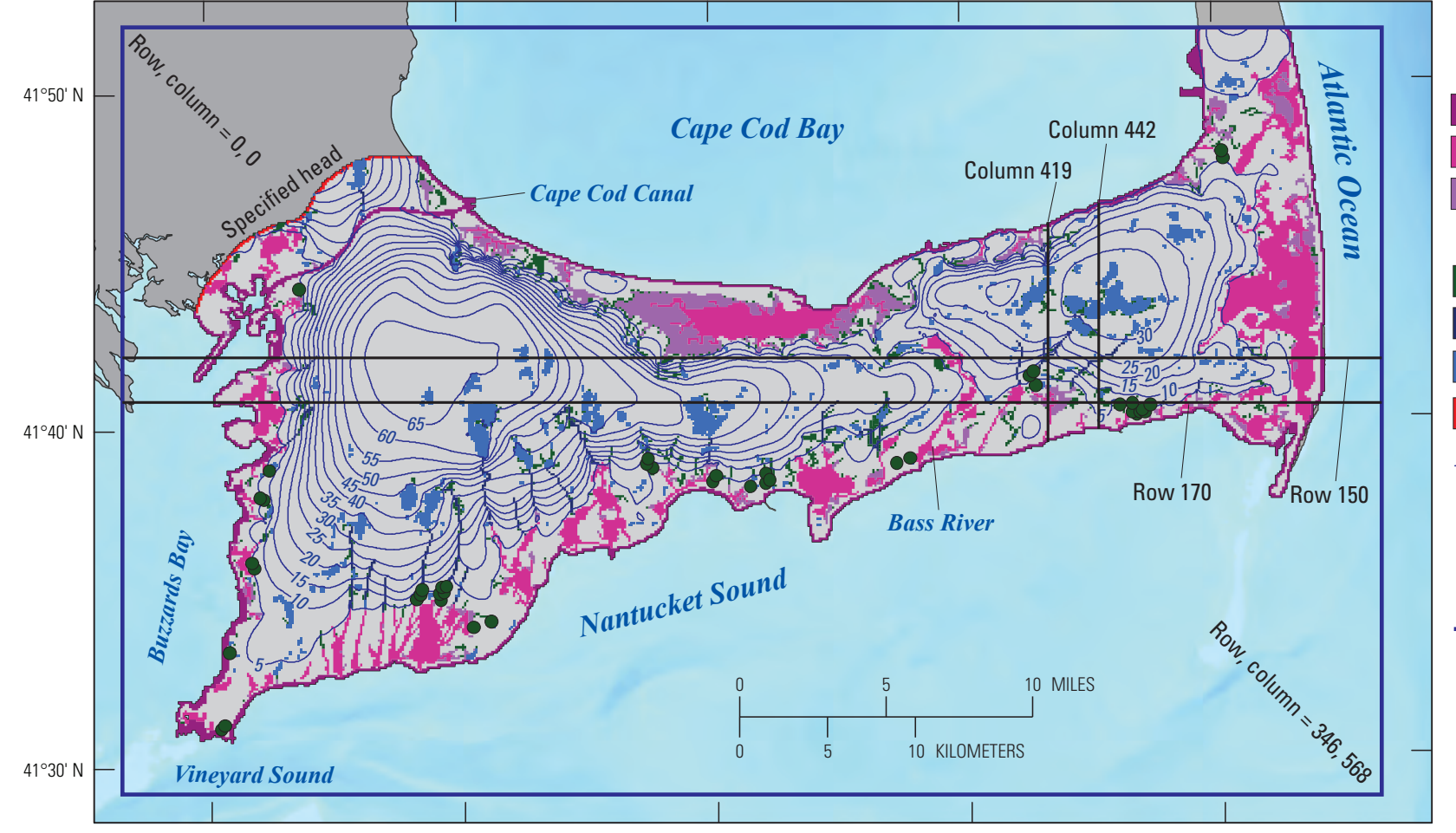

EXPLANATION

\section{Saltwater}

Coast

Estuary

Salt marsh

Freshwater

Wetland

Stream

Pond

Specified head

- 5- Water table contour-Shows

altitude of water table in 2011. Interval is 5 feet. Datum is National Geodetic Vertical Datum of 1929

\section{Groundwater model grid}

- Potential coastal pond
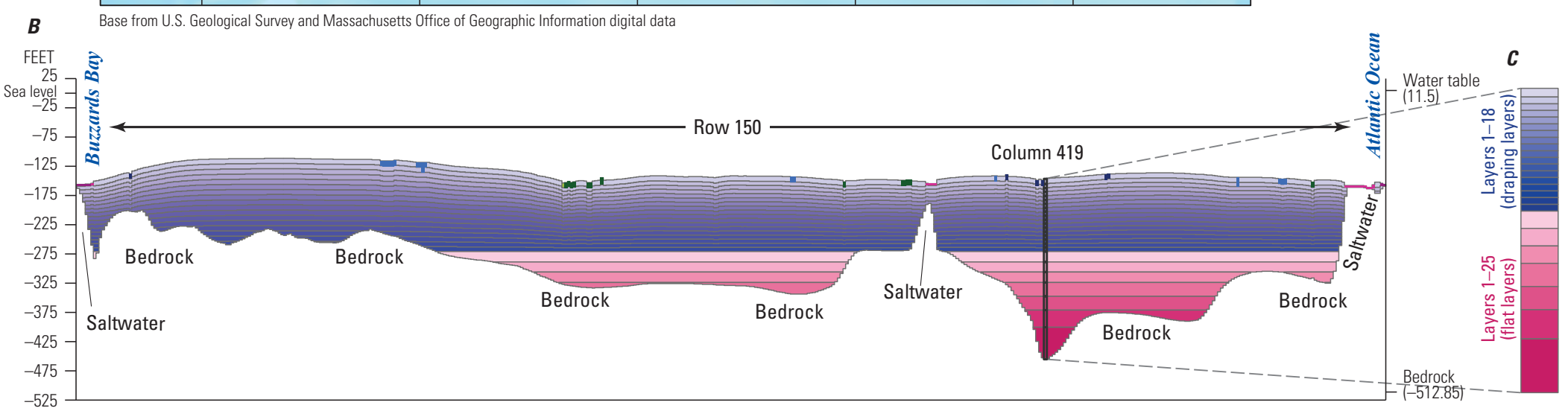

Figure 15. A, Model extent and hydrologic boundaries, locations of potential back-barrier coastal ponds, and simulated water table for $2010-11$ from a threedimensional groundwater flow model of central and western Cape Cod, Massachusetts. $B$, Cross section showing model layering along an east-west cross section

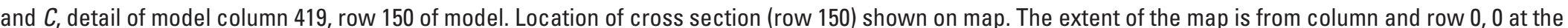
top left of the map to 568,346 at the bottom right of the map. 
marshes were derived from lidar data spatially averaged within each 400-ft boundary cell; the boundary altitudes of streams were specified as the minimum lidar value within each $400-\mathrm{ft}$ boundary cell.

Boundary leakances differed by boundary type and were equivalent to values obtained from the existing calibrated models for each type of boundary: $0.1,0.2$ and 1 foot per day [ft/d] for estuaries, open coastal waters, and streams, respectively. An additional set of hydrologic boundaries represented potential seeps at land surface, which would occur in areas where the water table potentially exceeded land surface. These features were represented as drains and were assigned to areas where the initial approximation of the water table, derived from existing calibrated models, was within $6 \mathrm{ft}$ of land surface. The boundary altitude was specified as the spatially averaged lidar data within the $400-\mathrm{ft}$ model cell.

Ponds, which are hydraulically important in the Cape Cod aquifer system, are represented as areas with essentially infinite horizontal and vertical hydraulic conductivities of 100,000 and 10,000 ft/d, respectively. This modeling method allows the ponds to respond to changes in hydraulic stresses and reasonably creates the hydraulic gradients observed upgradient and downgradient of flow-through ponds. The horizontal leakance between pond and aquifer was implicitly represented using the Horizontal-Flow Barrier package for MODFLOW (Hsieh and Freckleton, 1993), which allowed for a specified resistance to flow between adjacent model cells. Some ponds drain through surface-water outlets to streams. These pond outlets were represented as drains within the pond that have an essentially infinite leakance term and an altitude corresponding to the pond-surface altitude. The area of interest extends from the Cape Cod Canal eastward to Town Cove; however, the active model was extended to include parts of the adjacent Plymouth-Carver and Lower Cape Cod aquifers (fig. 12) to allow for these two hydrologic boundaries to be fully represented as dynamic features. The upgradient extents of the active parts of the Plymouth-Carver and Lower Cape Cod aquifers are represented as a specified head boundary; the heads were obtained from the two existing regional models (Masterson, 2004; Masterson and others, 2009).

\section{Aquifer Properties}

Horizontal and vertical hydraulic conductivity were derived from the existing regional models. Hydraulic conductivity was computed for each cell as the thickness-weighted average of hydraulic conductivities in the layer or layers of the corresponding regional model within each new model cell. This approach resulted in an essentially identical transmissivity for the full aquifer thickness of the new model and the corresponding existing model. The parts of the active model west of the Cape Cod Canal and east of Town Cove, outside of the area of interest, were specified as the thickness-weighted average of hydraulic conductivity over the full thickness of the corresponding model (Masterson, 2004; Masterson and others, 2009). Hydraulic conductivity within the region of the model that represents the Sagamore and Monomoy flow lenses was obtained from existing models of the two flow lenses. Hydraulic conductivity ranged from about $10 \mathrm{ft} / \mathrm{d}$, representing silty sediments primarily in deep parts of the simulated aquifer, to about $350 \mathrm{ft} / \mathrm{d}$, representing coarse sand and gravel in outwash and ice-contact deposits (fig. 2).

\section{Hydraulic Stresses}

The spatial variability of recharge arising from vegetation, soil type, and water capacity were computed using the SWB model (fig. 11). The areally averaged mean value of $21.9 \mathrm{in} / \mathrm{yr}(556.3 \mathrm{~mm} / \mathrm{yr})$ was used to normalize the estimated values in individual cells to multipliers of that mean value. These multipliers represented the variability of recharge within the modeled area and were applied to a parameter representing areally averaged recharge; this recharge parameter was adjusted during model calibration. The initial estimate of areally averaged natural recharge onto aquifer sediments was $27.5 \mathrm{in} / \mathrm{yr}(698.5 \mathrm{~mm} / \mathrm{yr})$ based on results of the calibration of the Sagamore and Monomoy flow lenses in Walter and Whealan (2005).

About 140 wells in 2010 withdrew water from the two flow lenses (fig. 16). Groundwater withdrawals from 85 production wells on the Sagamore flow lens were compiled as part of a national resources damage assessment (NRDA) project investigating water availability on western Cape Cod (Shira McWaters, Tata and Howard, Inc., written commun., 2013). Groundwater withdrawals for communities on the Monomoy flow lens (about 55 wells) were obtained from the Massachusetts Department of Conservation (Joe Cerutti, Massachusetts Department of Environmental Protection, written commun. 2014). About 19.7 and 8.5 million gallons per day of water were withdrawn from the Sagamore and Monomoy flow lenses, respectively. About 85 percent of this water was returned to the aquifer as discharged wastewater; the remainder is assumed to be consumptive loss. Most wastewater entered the aquifer as septic-system return flow in unsewered areas (fig. 16) and was distributed in the model using parcel-scale water-use data obtained from the MEP (Massachusetts Estuaries Project, unpub. data. Parcels were mapped to the model grid, and return flow in each cell was computed as the area-weighted mean of the parcel-scale return flow rate and was simulated as enhanced recharge. The remaining wastewater entered the aquifer at eight large wastewater treatment facilities (fig. 16) and also was simulated as enhanced recharge. Natural recharge and wastewater return flow were represented in the model by use of the $\mathrm{RCH}$ package for MODFLOW (McDonald and Harbaugh, 1988).

\section{Model Calibration}

The 3D regional model of the Sagamore and Monomoy flow lenses (fig. 15) was calibrated by adjusting model input parameters - hydraulic conductivity, boundary leakances, and recharge - to match observed long-term water levels, 


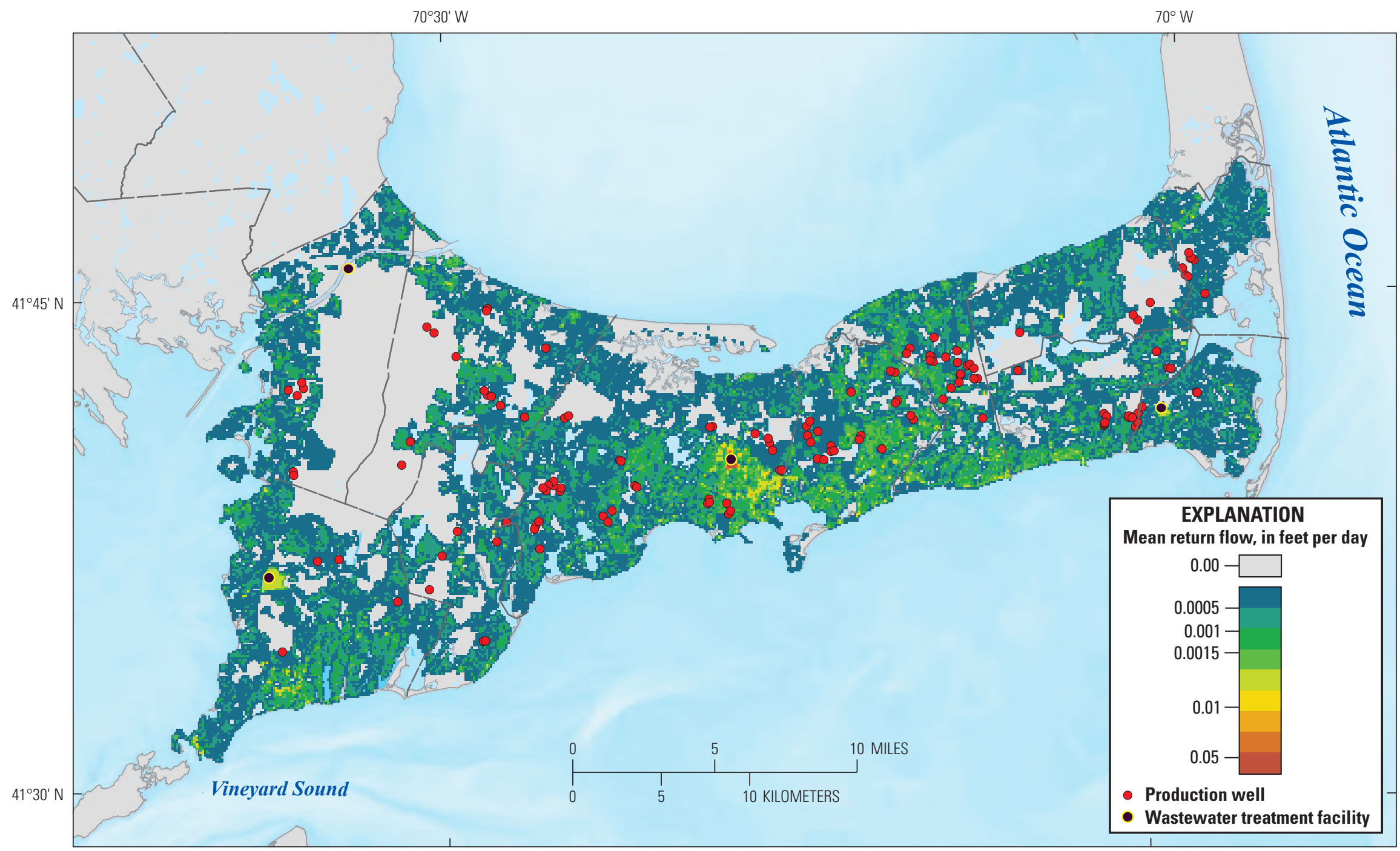

Base from U.S. Geological Survey and Massachusetts Office of Geographic Information digital data

Figure 16. Location of production wells in 2010 and return flow estimated from parcel-scale water use for central and western Cape Cod, Massachusetts. 
streamflows, and a regional groundwater divide. Previously published models of groundwater in the region have used a trial and error approach whereby parameters are manually adjusted until an acceptable fit to observations is achieved (Masterson and Barlow, 1994; Masterson and others, 1997b; Walter and Whealan, 2005). This approach can be used to produce calibrated models that reasonably match observed hydrologic conditions; however, the resulting parameters are highly nonunique, and the match to observed conditions does not represent a statistical best fit. Inverse calibration methods use nonlinear regression to estimate parameters that best fit observed hydrologic conditions. It should be noted that while inversely calibrated models produce a statistical best fit to observations of hydrologic conditions, the estimated parameters are a function of the location and types of observations, weights applied to those observations and the prior information on aquifer properties used in the regression.

Inverse calibration methods determine the model parameters that best fit a given set of observations using an iterative form of Gauss-Levenberg-Marquardt nonlinear regression to minimize an objective function (Levenberg, 1944; Marquardt, 1963). The objective function formulates the weighted fit between observations and simulated equivalents and can include prior information on aquifer characteristics. Two sets of tasks are required to utilize inverse calibration methods in model calibration: definition of model parameters that can be adjusted between regression iterations and conversion of observations to a form for which simulated equivalents can be computed from the model. In this analysis, the inverse calibration modeling software package PEST (Doherty, 2010) was used to calibrate the regional model of the Sagamore and Monomoy flow lenses. The software package allows for the use of highly parameterized model inputs and has a large degree of flexibility in defining observations as derived quantities.

The calibration period (1995-2000) generally is consistent with that for pumping stresses and return flow. This period generally predates the initiation of large-scale plume remediation at the JBCC and encompasses collection of water level and streamflow data. These groundwater withdrawal rates were used previously in the calibration of groundwater models of the Sagamore and Monomoy flow lenses (Walter and Whealan, 2005) and generally were similar by town to the 2010 pumping stresses used in this analysis.

\section{Model Parameterization}

Model inputs were expressed as parameters to facilitate an inverse calibration of model characteristics to observed steady-state hydrologic conditions. Three types of model parameters were included in the inverse calibration: recharge, boundary leakances, and hydraulic conductivity (horizontal and vertical). Initial parameters are derived from and are consistent with values in existing calibrated models of the Sagamore and Monomoy flow lenses (Walter and Whealan, 2005). The parameters were assigned upper and lower constraints that reflected a range of values that would be considered reasonable based on prior understanding of the system.

\section{Recharge and Boundaries Leakances}

Natural recharge is represented by two parameters: recharge onto aquifer sediments and onto pond surfaces. Pond recharge is specified as $16 \mathrm{in} / \mathrm{yr}(406.4 \mathrm{~mm} / \mathrm{yr})$, representing the difference between precipitation and pan evaporation for Cape Cod (Walter and Whealan, 2005) and was not varied during calibration; no recharge is specified for streams and wetlands. Recharge onto aquifer sediments is the only recharge parameter included in the inverse calibration regression. Multipliers of recharge, derived by normalizing values in individual cells - computed using the SWB method-to the average value of $19.3 \mathrm{in} / \mathrm{yr}(490.22 \mathrm{~mm} / \mathrm{yr})$, are used to spatially distribute recharge based on land use and soil characteristics. The parameter value applied to the multipliers, which represents the average recharge rate, was initially adjusted from 19.3 to $27.5 \mathrm{in} / \mathrm{yr}$ ( 490.22 to $698.5 \mathrm{~mm} / \mathrm{yr}$ ) to better reflect effective recharge rates for the Cape Cod aquifer based on the calibration of the model in Walter and Whealan (2005). An upper constraint of $30 \mathrm{in} / \mathrm{yr}(762 \mathrm{~mm} / \mathrm{yr})$, considered to be the upper limit of annual-average recharge, was assigned to the natural recharge parameter.

Leakances at boundaries refer to the vertical resistance to flow within surface water bottom sediments and are a function of both vertical hydraulic conductivity and the thickness of the bottom sediments; leakance at boundaries is therefore a lumped parameter. The vertical hydraulic conductivity of freshwater boundaries (including salt marshes) was specified to be $1 \mathrm{ft} / \mathrm{d}$. The coastal boundaries of open coastal waters and inland estuaries are represented as general-head boundaries in the regional model and had specified leakance of 0.2 and $0.1 \mathrm{ft} / \mathrm{d}$, respectively. The leakance between ponds and the aquifer, represented implicitly as horizontal flow barriers, initially was specified to be $30 \mathrm{ft} / \mathrm{d}$. These initial leakance values are similar to those obtained from calibrated models of the system from Walter and Whealan (2005). Leakances are not well understood and the leakance parameters were allowed to change during model calibration. Boundary leakances are a function of both hydraulic conductivity and bed thickness, both of which are poorly understood; this knowledge gap is reflected in the broad range of assumed reasonable valuesupper and lower constraints of 0.01 and $100 \mathrm{ft} / \mathrm{d}$, respectively.

\section{Hydraulic Conductivity}

Horizontal and vertical hydraulic conductivity parameters were defined using a combination of zones and pilot-point parameters. Parameter complexity using only zones of piecewise constancy and Gauss-Levenberg-Marquardt nonlinear regression generally is limited by the need for a given problem to be invertible for a solution to be achieved. Overly complex parameterization schemes can result in highly correlated or insensitive parameters that can limit the 
ability to achieve a reasonable solution or an acceptable fit to observations. The use of pilot points allows parameters to be represented at discrete points and regions between each pilotpoint parameter to be defined by kriging (Oliver and Webster, 1990) using the estimated values at the points (Doherty, 2003). This approach, when combined with singular value decomposition (SVD; Doherty and Hunt, 2010), can allow for complex and gradational hydraulic conductivity fields and, often, an improved fit to observations. The method also allows for the use of regularization to balance prior information on hydraulic conductivity with fit to observations, which allows for the preservation of geologic knowledge and can minimize overfitting to observations that can arise in highly parameterized models.

The simulated aquifer system was zoned using recently updated and digitized geologic quadrangles for central and western Cape Cod (fig. 2A; Stone and DiGiacomo-Cohen, 2009). This broad zonation represents a reasonable limit of prior geologic knowledge at a regional scale; no arbitrary zones were defined within the surficial geology zones. There are two minor differences between the mapped surficial units (fig. 2) and their representation in the regional model (fig. 17A). The Buzzards Bay ground moraine (0gm) geologic unit, which consists of small, disconnected entities within the broad Buzzards Bay outwash plain (fig. 2), was included as part of the surrounding outwash plain (fig. 17A) and the extensive Glacial Lake Cape Cod deposits (fig. 2) were separated into distinct eastern and western parts (fig. 17A). The active model areas to the west of the Cape Cod Canal and to the east of Town Cove, which are outside the area of interest, were excluded from the calibration (fig. 17A), and the initial hydraulic conductivity was not changed.

The pilot-point network consists of 635 pairs of horizontal and vertical hydraulic conductivity parameters within the 12 aquifer zones (fig. 17A). The pilot points are defined at regular interval of 4,000 ft across the Sagamore and Monomoy flow lenses. Only pilot-points within a zone are used to generate, by kriging, the hydraulic conductivity fields within that zone. The pilot points are applied to three separate vertical groups: group 1 contains layers 1 to 6 , group 2 contains layers 7 to 15 , and group 3 contains layers 16 to 25 (fig. 17B). The aquifer extent decreases monotonically with depth, and the number of pilot-points decreases with depth as the lateral extent of the zones decreases (fig. 17B). There are 635, 531, and 377 pairs of pilot-point parameters in groups 1, 2, and 3, respectively, and a total of 1,543 separate pilot-point parameters pairs (a total of 3,086 hydraulic conductivity parameters). Only the top layer of each vertical group has pilot points defined. The hydraulic conductivity field is estimated by kriging for the top layer of each group following perturbation of a pilot point; the resultant fields are then copied into the lower layers of each group prior to input into the model. This simplification was possible owing to the monotonic decrease in the lateral extent of the aquifer with depth as defined by the bedrock and the surfaces of the freshwater/saltwater interface (fig. 17B).
Initial values of hydraulic conductivity were computed from the hydraulic conductivity fields derived from existing models and mapped to the new model grid. The thicknessweighted mean horizontal hydraulic conductivity of the layers within each of the three vertical parameter groups (fig. 17B) at each row and column containing a pilot point were assigned to be the initial value of hydraulic conductivity for that pilot point; geometric means were used for computing the initial values of vertical hydraulic conductivity. Upper and lower constraints of 10 and $350 \mathrm{ft} / \mathrm{d}$, respectively, were assigned to horizontal hydraulic conductivity, and constraints of 1 and $100 \mathrm{ft} / \mathrm{d}$, respectively, were assigned for vertical hydraulic conductivity in all three vertical groups. The use of inverse calibration techniques allow for different types of prior geologic knowledge to be incorporated into model calibration as a balance between existing knowledge and model fit to observations. The glacial sediments underlying Cape Cod generally become finer with depth (fig. $2 B$ ). Lower constraints were used to enforce this grain-size pattern during calibration of alternate models and test the balance between adherences to the depositional model and fit to observations.

\section{Observations and Weighting}

Observations of long-term average (steady-state) heads, streamflows, and a regional groundwater divide were used to formulate the objective function used in the inverse calibration of the groundwater-flow model. The objective function includes individual terms for each observation that are each equal to the square of the difference between the observed quantity and the simulated equivalent multiplied by the weight of the observation; the weight is the inverse of an estimate of error associated with the observation. Weighting reflects the confidence in the observation and, to a degree, the importance of the observation. Weighting can represent physically based errors associated with the measurement; however, such estimates are often difficult to quantify. The use of a diverse set of observations with differing units can complicate weighting schemes based strictly on estimates of error. This is further exacerbated by differing numbers of observations of different groups because a larger number of observations - even with relatively small values of misfit - can overwhelm the objective function such that groups with more observations or larger units can have disproportionate influence on the regression. It is also difficult to quantify the error incurred by modeling assumptions and structure (Doherty and Welter, 2010).

An alternative is to use a relative weighting scheme whereby a more qualitative measure of the importance of a set of observations, as indicated by the part of the objective function a given group of observations contributes to the total value, can be used to order weights to reflect the user's confidence in individual groups. Initial weights are set based strictly on assumption of error, but they can be adjusted to trade off the desired influence of specific groups based on the factors mentioned above. This level of subjectivity importantly improves the results provided there is disclosure of the 
A

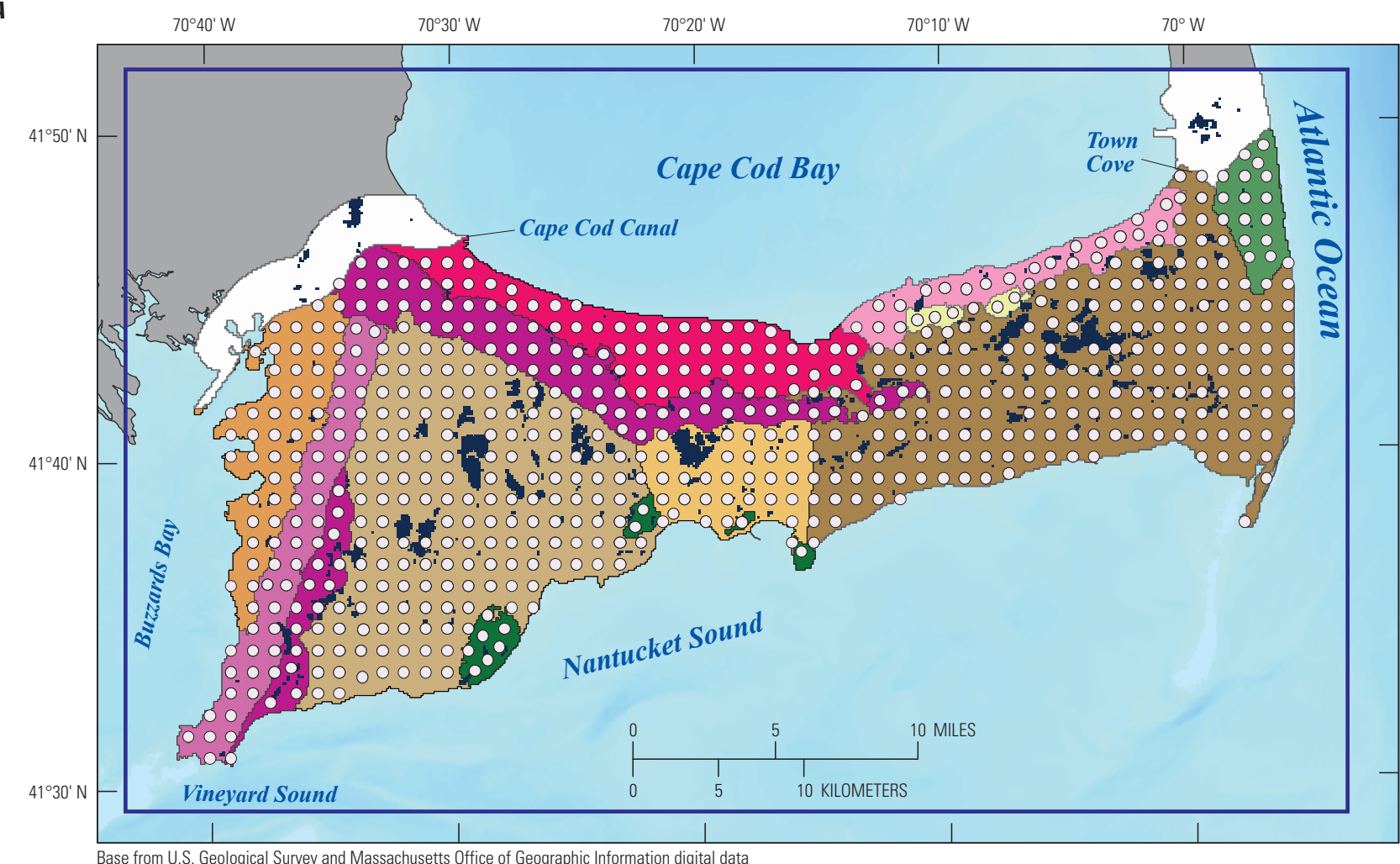

\section{EXPLANATION}

Parameter zones

Outwash

Buzzards Bay

Mashpee

Barnstable

Harwich

Lacustrine

Lake Cape Cod (east)

Lake Cape Cod (west)

Moraine

Buzzards Bay

Mashpee

Ice contact

Nauset

Nantucket

$\square$ Excluded zone

Pond

- Groundwater model grid

- Pilot-point parameter

Parameter group_-Indicates depth of land area in schematic view

B

Shallow
Middle

Deep

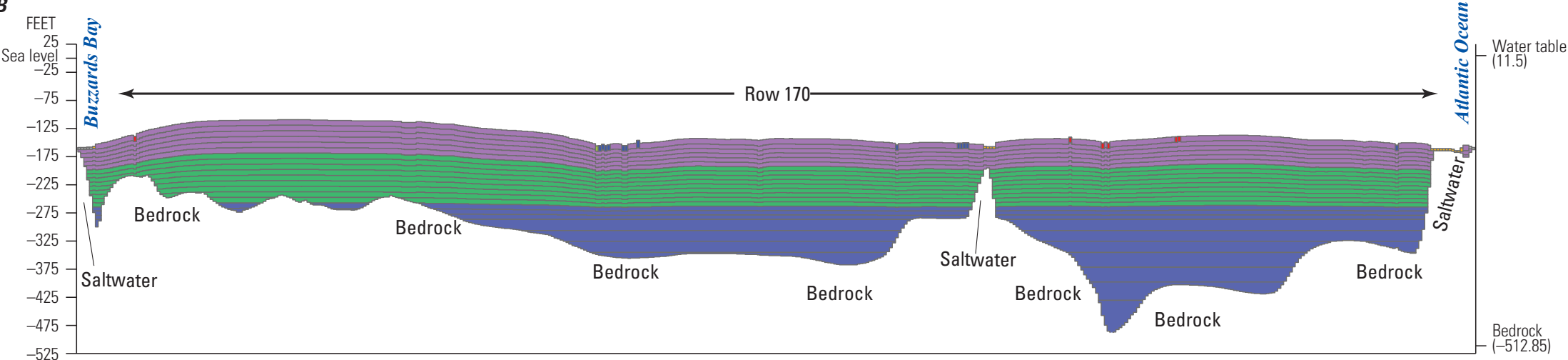

Figure 17. A, Parameter zones and locations of pilot-point parameters for the groundwater flow model of the Sagamore and Monomoy flow lenses on Cape Cod,

Massachusetts. $B$, Cross section along row 170 of the model showing vertical parameter groups. 
assumptions made (Fienen, 2013). The use of relative weighting requires that observations be grouped in a way that reflects similar units and confidence in the value of the observation. The inverse calibration in this study used a relative-weighting scheme owing to the diverse set of observation types, the difficulty in assigning physically based measures of error to inferred observations, and difficulty in quantifying the degree to which steady-state observations match true average conditions. The development of a reasonable weighting scheme is a subjective, knowledge based process that often involves evaluation of several alternatives.

Observations of water levels and streamflows were differentiated by confidence in the degree to which the observations represented long-term hydrologic conditions. This resulted in four observation groups. Long-term water levels in 47 wells and ponds with records longer than 30 years were a representative group that was weighted highly. Average water levels from 582 wells with partial records were considered less reliable measures of steady-state conditions and were assigned weights that were substantially lower (about 12.5 times) than weights for long-term water levels. The total of 15 highly weighted streamflows included two sites with continuous records - the Quashnet River and Herring River sites - and partial-record measurements collected in May 2002 as part of near-average synoptic measurements (Walter and Whealan, 2005). Some additional partial-record sites with numerous measurements during periods determined to be near average were included with highly weighted observations. The remaining streamflow observations were considered to be less reliable indicators of long-term average hydrologic conditions and were given lower weights in formulation of the objective function. These included sites with a limited period of record, anomalous streamflow values, or the possible influence of unknown pond outflows or pumping on the measurements.

The weighting of observations is a reflection of confidence in different observations, and different weighting schemes affect the results of an inverse calibration. A total of six observation groups were included in the objective function: high weighted wells, two groups of low weighted wells (data from the USGS and from other sources), high weighted streams, low weighted streams, and the location of a regional groundwater divide. The weights, computed as their contribution to the initial objective function, were $57,28,5,5,3$, and 2 percent, respectively.

\section{Model Fit to Observations}

A Gauss-Levenberg-Marquardt nonlinear regression is a gradient-based technique that minimizes the weighted misfit between observations and model-calculated equivalents. The nonlinearity of the system requires an iterative approach to minimization. Observation sensitivities with respect to each parameter are computed by perturbing (by 1 percent) individual parameters and evaluating the change in simulated equivalents for each observation; this process requires a model run for each parameter and results in a matrix of sensitivities, referred to as a Jacobian matrix. The Jacobian matrix is computed initially and updated between successive iterations to guide the nonlinear regression. Exploratory runs between each iteration are performed to determine the local objective function gradient, update parameter values, and lower the value of the objective function. This process is repeated until updated parameters change by less than specified closure criteria (1 percent) and the regression is considered to be complete.

SVD is used to improve stability in regressions with a large number of parameters by suppressing variability of insensitive parameters based on a user-defined range of eigenvalues (analogous to sensitivities) from SVD performed on the weighted Jacobian matrix (Doherty and Hunt, 2010). In addition, the singular-value decomposition (SVD)-based parameter estimation methodology SVD Assist (SVDA) of PEST (Tonkin and Doherty, 2005) is used to more efficiently manage model run times by reducing the number of parameters to fewer linear combinations of parameters, referred to as superparameters. Application of SVDA assumes that the model generally is linear and that a full Jacobian matrix does not need to be computed for each successive iteration of the regression.

The inverse calibration uses regularization to balance the fit to observations with prior geologic knowledge of the aquifer, primarily in the form of initial hydraulic conductivities. Regularization allows for the inclusion of existing information as a penalty term in the objective function. As the fit to observations improves and that component of the objective function decreases, departures from initial parameter values increase the value of the penalty term and offset the total decrease. Regularization can enforce either smoothness between parameters or the initial value of the parameter. The latter, referred to as preferred value regularization, is used in the calibration in this report. The initial parameter values are assumed to represent existing knowledge of the general distribution of hydraulic conductivity as derived from previously calibrated models (Walter and Whealen, 2005). The variable in PEST that controls the relative importance of the two components is PHIMLIM; a value equal to the number of observations was used in the regression based on previous research into the optimal use of the PHIMLM variable (Fienen and others, 2009).

The conceptual model of the system differs substantially in some ways from the models of the Sagamore and Monomoy flow lenses of Walter and Whealan (2005). Bedrock altitude, representation of the freshwater/saltwater interface, hydrologic boundaries, recharge distribution, and land surface altitude were improved in the new model. As a result, the absolute mean differences between observed and simulated heads and streamflows were about 4.2 and $2.5 \mathrm{ft}^{3} / \mathrm{s}$, respectively, indicating that the initial parameter values did not match the new set of observations sufficiently well.

Inverse calibration regressions were repeated for four model variants for which differing sets of constraints on horizontal hydraulic conductivity were specified, representing existing geologic knowledge in the form of a depositional model in which grain size decreases with depth (fig. 2B). For 
the four model variants $(1-4)$, the lower constraints on horizontal hydraulic conductivity parameters in vertical group 1 were $100,70,30$, and $10 \mathrm{ft} / \mathrm{d}$, representing decreasing freedom in estimated parameters. Hydraulic conductivity parameters in vertical group 2 had lower constraints of 50, 30, 20, and $10 \mathrm{ft} / \mathrm{d}$. The lower constraint on horizontal hydraulic conductivity for vertical group 3 was $10 \mathrm{ft} / \mathrm{d}$, and the lower constraint on vertical hydraulic conductivity for all four model variants was $1 \mathrm{ft} / \mathrm{d}$. The four calibrated models represent increasing geologic constraint as indicated by a smaller range of allowable parameter values; variant 1 has the largest range of allowable parameter values and the smallest constraint and variant 4 has the smallest range of allowable parameter values and largest constraint (fig. 18).

The inverse calibration regressions improved model fit substantially in all cases. Model fit, as quantified by absolute mean residuals between observations and simulated equivalents (fig. 18), was dependent on the degree to which vertical grain-size patterns were enforced using low hydraulic conductivity constraints. The fit to observations varied among the four regressions and differed for observations with different weights. Highly weighted observations have the largest contribution to the objective function and effect on the regression; so, as could be expected, these observations show the largest differences in absolute mean residuals for the four different constraints (fig. 18). Absolute mean residuals for water levels for highly weighted wells increased from 0.30 to $1.88 \mathrm{ft}$ (indicating less fit) with increasing lower constraints on hydraulic conductivity, representing less freedom in estimated parameters. Residuals for streamflow for highly weighted streams increased from 0.29 to $1.59 \mathrm{ft}^{3} / \mathrm{s}$ over the same range of constraints. It should be noted that the largest head residual was still only about 2.6 percent of the total head difference though the system (about $70 \mathrm{ft}$ ) indicating that all regressions yielded models that can be considered calibrated with respect to water levels.

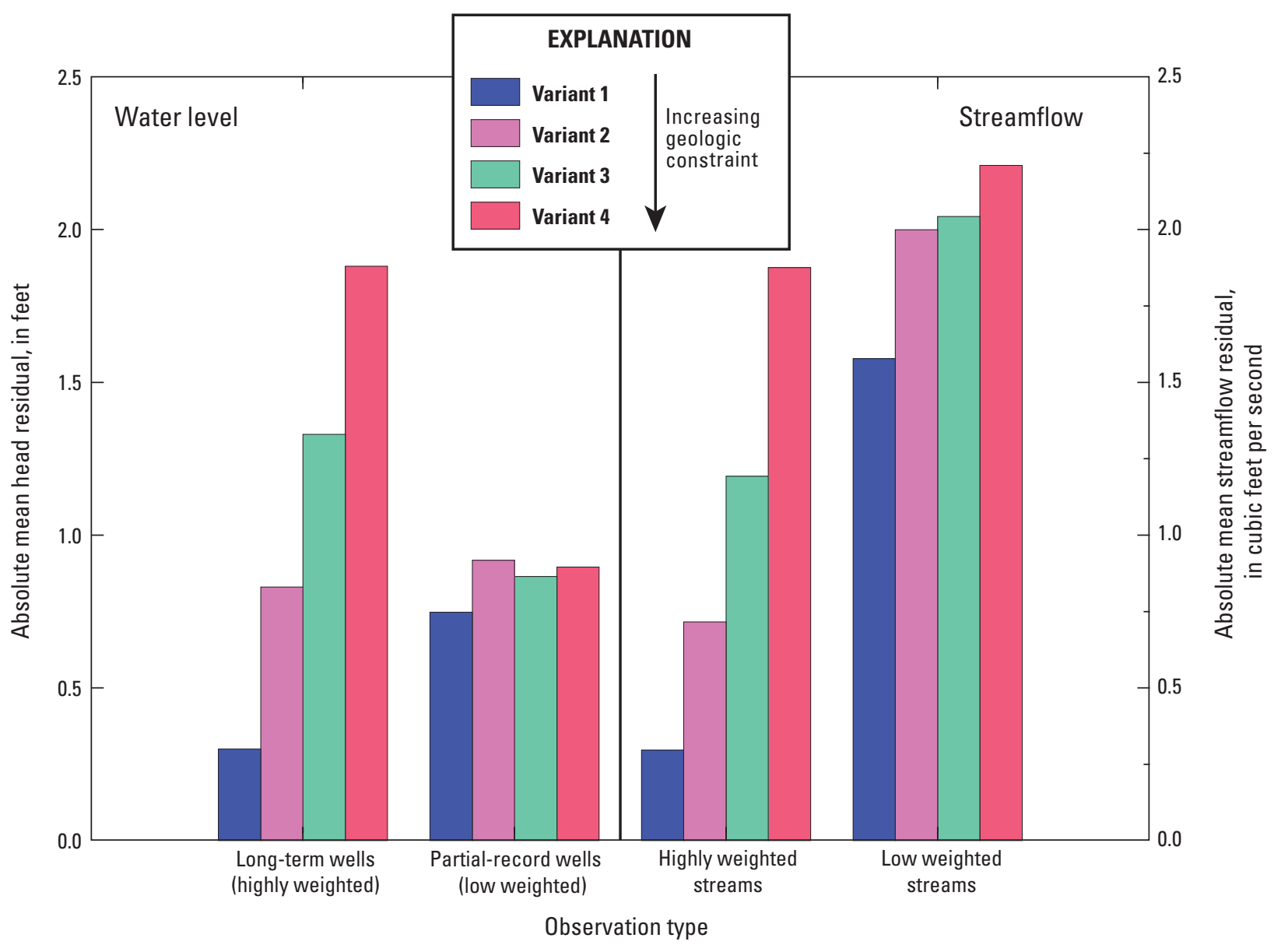

Figure 18. Absolute mean residuals for head and streamflow observation groups for four model variants with increasing geologic constraints. 
The regression with a lower constraint of $10 \mathrm{ft} / \mathrm{d}$ in all vertical groups and the most freedom for estimated parameters had the best fit to observed heads and streamflows (fig. 18). Observed and simulated water levels generally were in close agreement (fig. 19A). The absolute mean residual for the longterm wells was $0.30 \mathrm{ft}$; absolute mean residuals for the remaining groups - partial-record wells measured by the USGS and JBCC — were 0.84 and $0.68 \mathrm{ft}$, respectively. The residuals for the long-term wells had a mean of about $0.01 \mathrm{ft}$ with no discernible trends with respect to simulated values (fig. 19B). Partial-record wells (from the USGS and JBCC) also had mean residuals near zero ( 0.04 and $0.10 \mathrm{ft}$, respectively) with no trends with respect to simulated equivalents (fig. 19B), indicating little model bias. Simulated streamflow at 15 locations where measurements were considered representative of long-term average conditions were in close agreement (fig. 20). The absolute mean residual at these highly weighted observations was about $0.29 \mathrm{ft}^{3} / \mathrm{s}$. The observed and simulated streamflows at sites with continuous records- the Quashnet River and Herring River-were 0.11 and $0.48 \mathrm{ft}^{3} / \mathrm{s}$, respectively. The absolute mean residual at 23 additional sites where measurements were assigned lower weights in the objective function than the highly weighted observations was about $1.59 \mathrm{ft}^{3} / \mathrm{s}$. The observed and simulated location of the regional groundwater divide on the Sagamore flow lens, as defined by mapped contaminant plumes, differed by $322 \mathrm{ft}$, which was within the dimensions of one model cell.

The inverse calibration regression with a lower constraint of $10 \mathrm{ft} / \mathrm{d}$ in all vertical groups was used in this analysis because hydraulic conductivity parameters were within the range of reasonable values, the improved fit to observed heads was most appropriate to predictions of depths to water, and it was the only regression that yielded an estimated recharge rate $(28.7 \mathrm{in} / \mathrm{yr} ; 728.98 \mathrm{~mm} / \mathrm{yr})$ that was less than the upper reasonable range of $30 \mathrm{in} / \mathrm{yr}(762 \mathrm{~mm} / \mathrm{yr})$. The mean horizontal hydraulic conductivity for model layers within the three vertical parameter groups (groups 1, 2, and 3 with increasing depth) were 134, 61, and $22 \mathrm{ft} / \mathrm{d}$; all values were within the range of values considered reasonable for unconsolidated glacial sediments (10 to $350 \mathrm{ft} / \mathrm{d}$ ). Vertical hydraulic conductivity values were estimated independently from horizontal conductivity and averaged 38,10 , and $3 \mathrm{ft} / \mathrm{d}$ for the three parameter groups; the resulting mean vertical anisotropy ratios were about 5.7, 8.2, and 12.4. The calibrated values for boundary leakances were similar to the initial values (between $0.1 \mathrm{ft} / \mathrm{d}$ for estuarine sediments and $1 \mathrm{ft} / \mathrm{d}$ for streambeds), reflecting the low sensitivities of the simulated equivalents to heads and flows to these parameters. The estimated parameter valueshydraulic conductivity, leakance, and recharge - were incorporated into modified versions of the model to facilitate simulation of the effects of sea-level rise on the hydrologic system.

\section{Simulation of Sea-Level Rise}

Estimates of sea-level rise of 2, 4, and $6 \mathrm{ft}$ were used in this analysis to evaluate the response of the water table to elevated sea levels and the resulting changes in depth to water on central and western Cape Cod. A sea-level rise of $2 \mathrm{ft}$ is generally equivalent to the mean of estimates from the Intergovernmental Panel on Climate Change (Pachauri and Meyer, 2014) and may represent a low estimate in many regions of the globe, particularly areas such as the northeastern United States. A sea-level rise of $6 \mathrm{ft}$ generally is equivalent to the upper limit (95th percentile) of a population of predictions more fully accounting for ice-sheet dynamics. A sea-level rise of $4 \mathrm{ft}$ is an intermediate value between the two end-member projections. The timing of sea-level rise is unknown, and the values of 2 and $4 \mathrm{ft}$ can be considered either as intermediate sea levels prior to the upper value of $6 \mathrm{ft}$ by 2100 or as alternate, lower projections of sea level by 2100 .

The modifications for each sea-level-rise scenario $(2,4$, and $6 \mathrm{ft}$ above 2011 levels) include changes in model boundaries to reflect coastal geometries - derived from lidar data - consistent with each increased sea level and incorporation of the freshwater/saltwater interface positions computed for that sea level using the coastal model, as described in the "Simulation of Regional Freshwater/Saltwater Interface" section of this report. Changes in boundary conditions in areas where seawater inundation is likely, such as near Waquoit Bay, include conversion of fresh and salt marshes and dry land to coastal waters (estuaries or open coastal waters) and conversion of freshwater streams to tidal rivers (fig. 21). Boundary altitudes representing the new base level of the aquifer are specified as the freshwater-equivalent heads computed from the elevated sea levels and lidar data. Recharge, pumping, and return-flow stresses were not changed for the three sealevel rise scenarios, only the geometry of fresh and salt water boundaries and the position of the fresh/salt water interface.

The top of the model is land surface derived from lidar data, and the top model layer is simulated as unconfined. The same draped layering scheme is used for all models used to simulate elevated sea levels (fig. 22). The dynamic freshwater/ saltwater interface, derived from the simulated interface for each sea level, is assumed to be sharp and is incorporated into the model as a no-flow boundary. Model grids are identical in areas where the aquifer is underlain by bedrock for all sealevel rise scenarios, but differ where the aquifer is underlain by the simulated freshwater/saltwater interface (fig. 22). The altitude of the freshwater/saltwater interface generally increases and the aquifer thins as sea levels rise. Using the interface position to truncate the model grid results in the conversion of active model cells at depth to inactive cells. The simulated interface altitude at an example location (row 150, column 419) on the Monomoy flow lens was $388 \mathrm{ft}$ below NAVD 88 for sea level in 2011 (fig. 22). The interface position for sea levels 2, 4, and $6 \mathrm{ft}$ above the sea level in 2011 were 

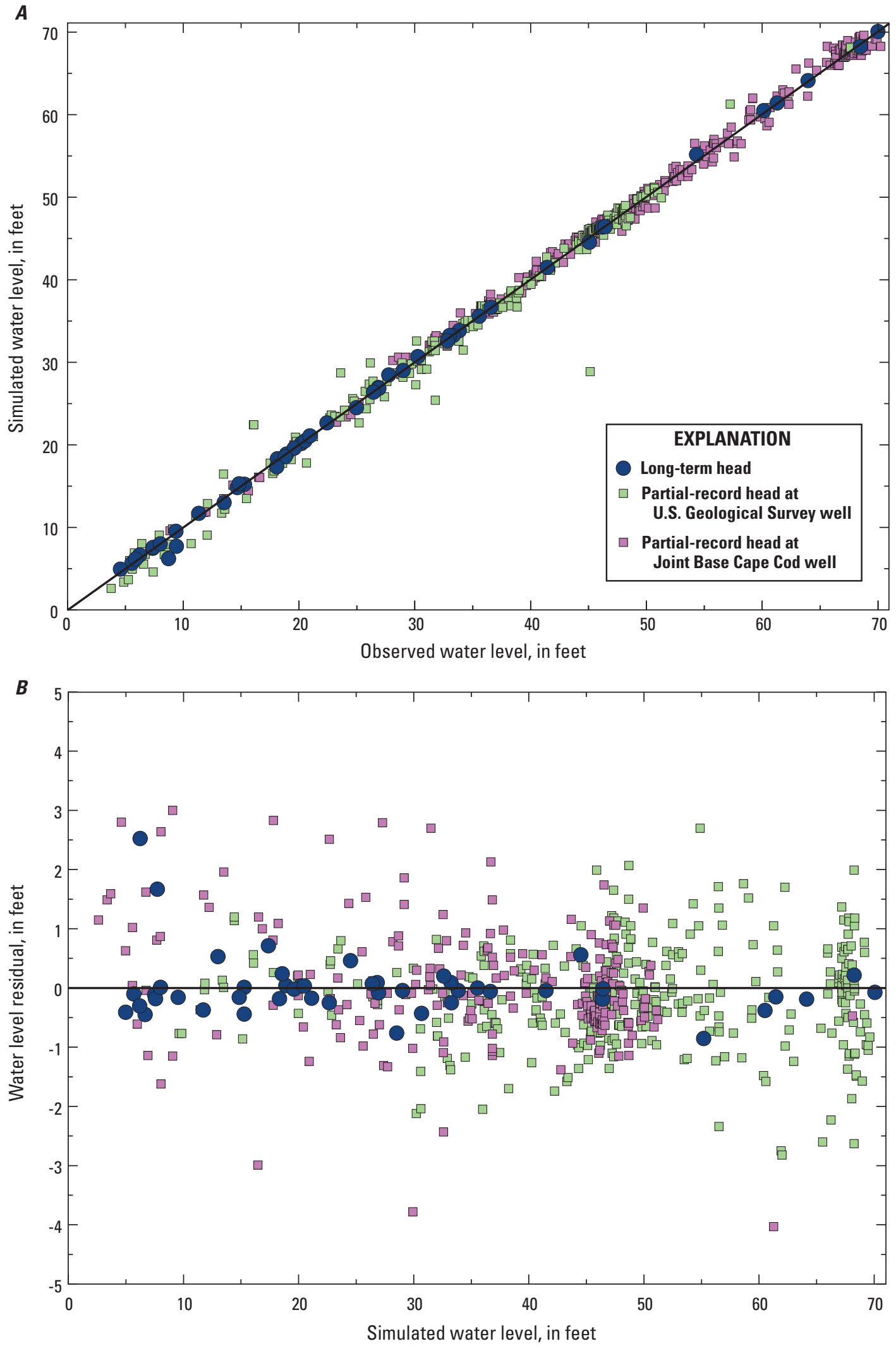

Figure 19. $A$, Observed water levels and simulated equivalents and $B$, distribution of head residuals with simulated equivalents for calibrated model of the Sagamore and Monomoy flow lenses, Cape Cod, Massachusetts. 


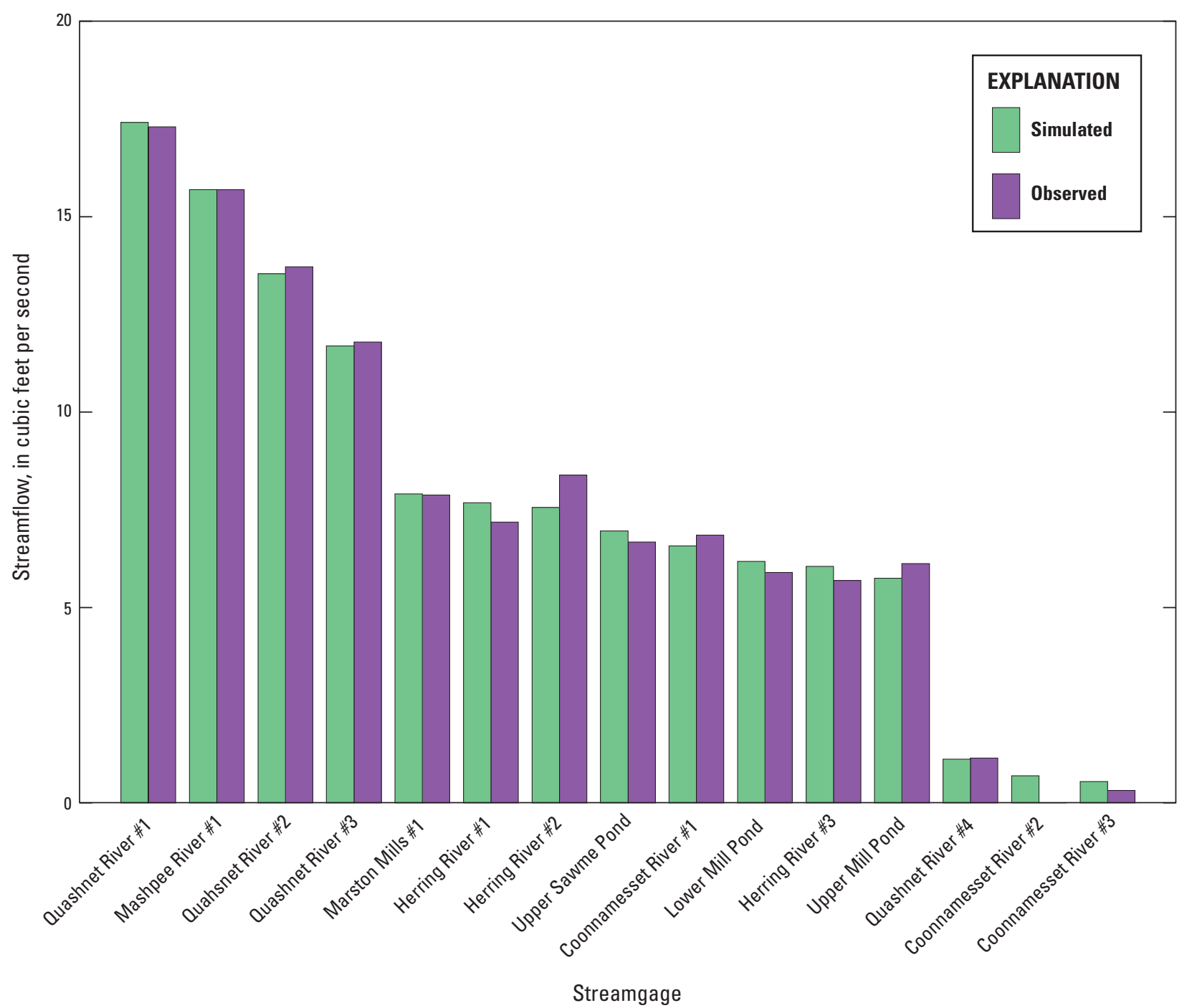

Figure 20. Observed and simulated streamflows for highly weighted observations for calibrated model of central and western Cape Cod, Massachusetts. The Quashnet River \#1 and Herring River \#1 sites are long-term monitoring streamgages.

336,275 , and $225 \mathrm{ft}$ below NAVD 88, respectively. The bottom of the active model (the bedrock surface) at the example location for the sea level in 2011 is in layer 24; the bottom of the active model for sea levels 2,4 , and $6 \mathrm{ft}$ above the sea level in 2011 were layers 23, 21, and 19, respectively (fig. 22).

\section{Effects of Sea-Level Rise on Water Table Altitudes and Depths to Water}

The simulated water table (fig. 23A) on the Sagamore and Monomoy flow lenses ranges from about $69 \mathrm{ft}$ to less than $1 \mathrm{ft}$ for "current" conditions (groundwater withdrawals in 2010 and sea level in 2011). The highest water table altitude (about $69 \mathrm{ft}$ ) is in the north-central part of the Sagamore flow lens. Hydraulic gradients generally are larger near streams and along the northern shore, adjacent to Cape Cod Bay, and smaller along the southern shore where the aquifer system is drained by large streams. Hydraulic gradients are radially outward from the highest level of the water table; and an eastwest groundwater divide extends east to the Bass River. The highest water altitude (about $31 \mathrm{ft}$ ) on the Monomoy flow lens is to the northeast of Long Pond. The water table also has a second high level (30 ft) in the northwestern part of the flow lens; hydraulic gradients are radially outward from these two distinct divides.

A total of about $626 \mathrm{ft}^{3} / \mathrm{s}$ of natural recharge enters the aquifer system of central and western Cape Cod: about $448 \mathrm{ft}^{3} / \mathrm{s}$ on the Sagamore flow lens and about $182 \mathrm{ft}^{3} / \mathrm{s}$ on the 


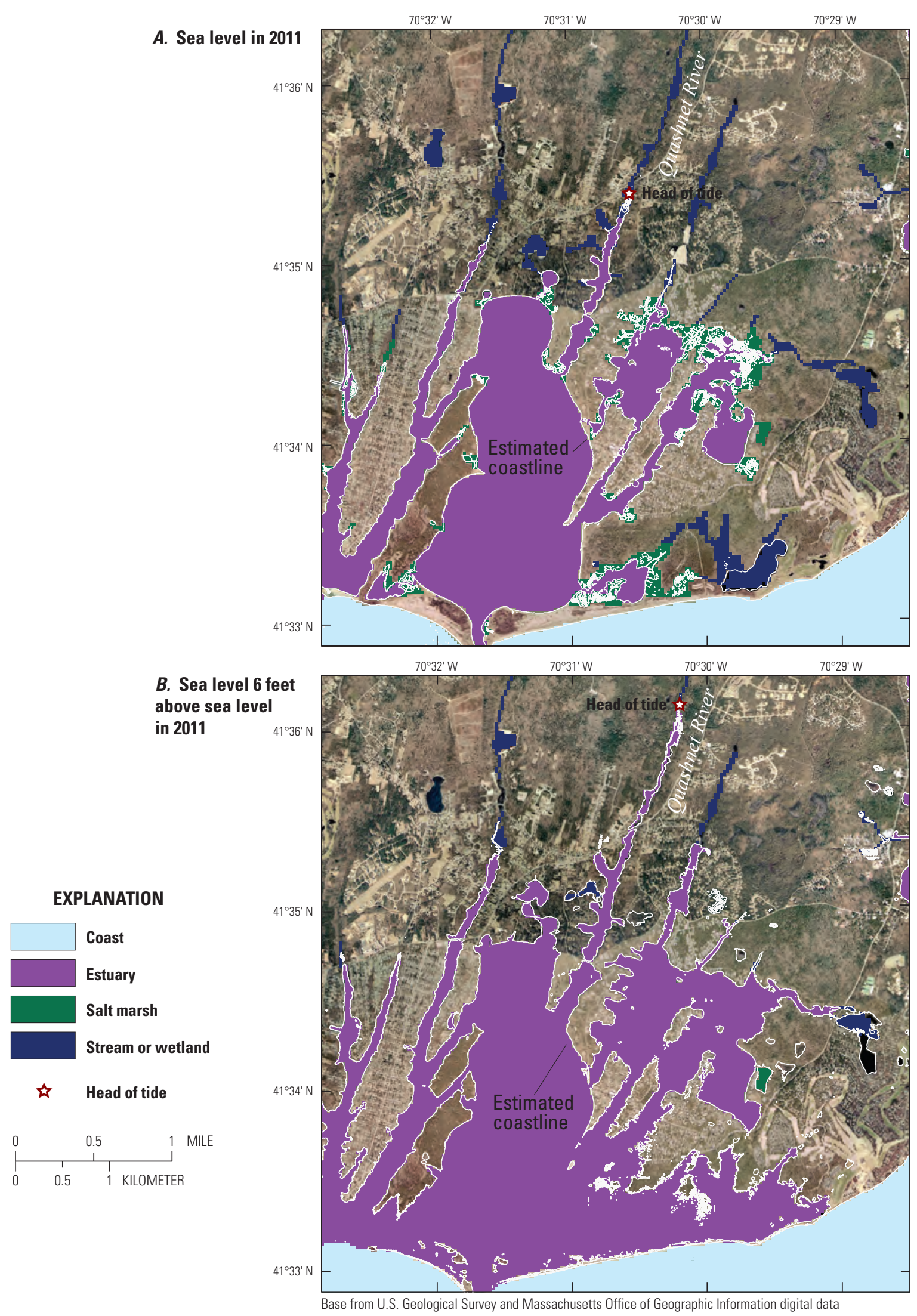

Figure 21. Coastal geometry estimated from 1-meter light detection and ranging (lidar) data assuming static coastal landforms and simulated hydrologic boundaries for $A$, sea level in 2011 and $B$, sea level 6 feet above 2011 sea level in Falmouth on Cape Cod, Massachusetts. The head of tide is for the tidal current. Location of area shown in figure 5. 


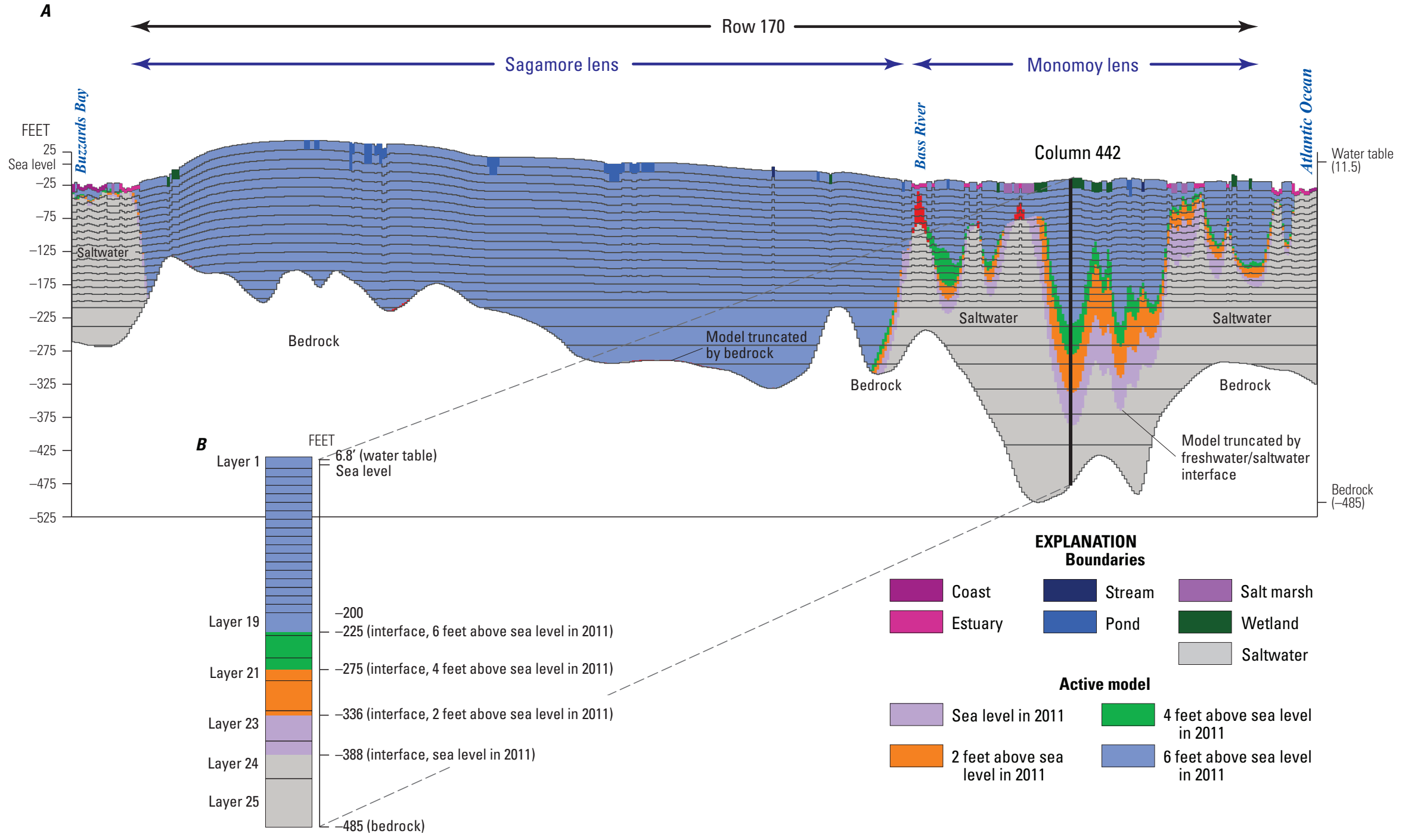

Figure 22. Model layers and boundaries for simulation of sea level in 2011 and sea levels 2, 4, and 6 feet above 2011 sea levels along an east-west cross section (model row 150) through the model of the Sagamore and Monomoy flow lenses, Cape Cod, Massachusetts. Location of model row shown on figure 15. 


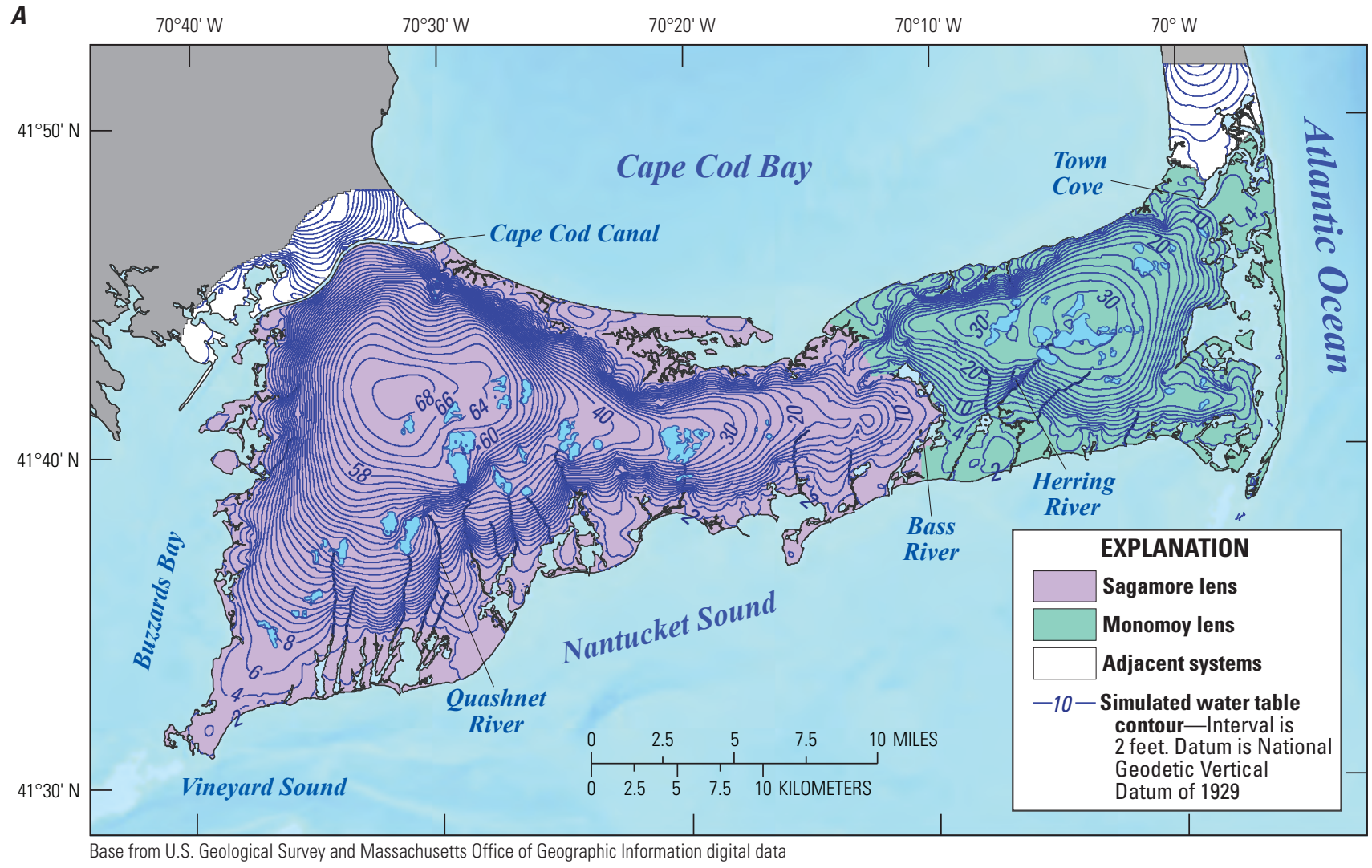

B

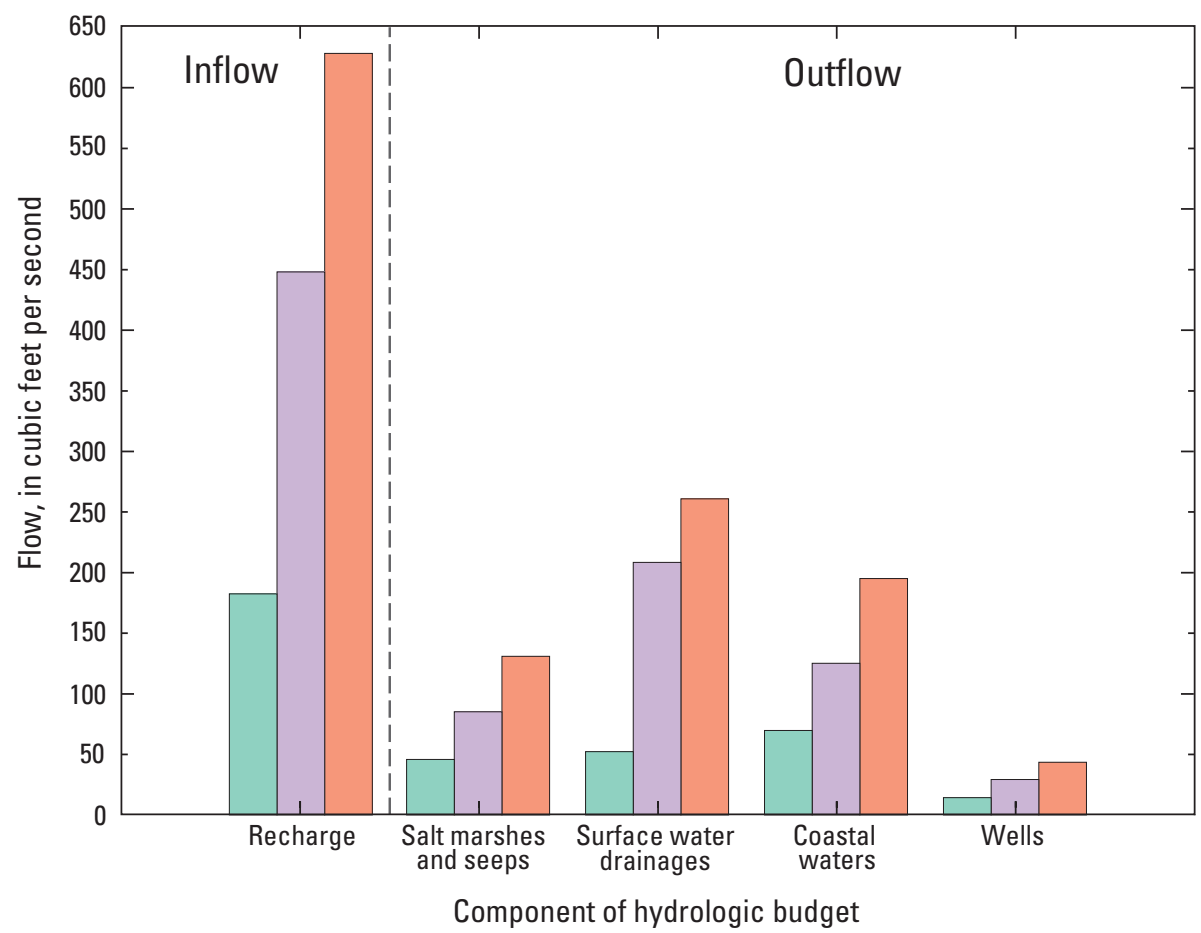

\section{EXPLANATION}

Monomoy

Sagamore

Combined

Figure 23. A, Simulated water table for current conditions and $B$, graph showing general hydrologic budget for the Sagamore and Monomoy flow lenses, central and western Cape Cod, Massachusetts. 
Monomoy flow lens (fig. 23B). Water discharges naturally into surface drainages, including streams, pond outlets, and drained wetlands near streams; salt marshes and adjacent seeps; and coastal waters, including estuaries, tidal rivers, and the ocean. About 41, 21, and 31 percent of recharged water for both flow lenses discharges to these three drainages, respectively. About 7 percent of recharged water is withdrawn from wells, but most of that (85 percent) reenters the aquifer as return flow.

Groundwater discharge among the three types of drainages differs in proportion to the inflows for the two flow lenses. About 28 and 38 percent of recharged water discharges into coastal waters on the Sagamore and Monomoy flow lenses, respectively. Salt marshes and land surface seeps on the two flow lenses receive 19 and 25 percent of recharged water on the Sagamore and Monomoy flow lenses, respectively. The two flow lenses have differing hydrography (fig. 23A); the Sagamore flow lens has several large ponds with outflows and streams, including the largest stream on Cape Cod (Quashnet River), whereas the Monomoy flow lens has fewer large surface water features and one major drainage system (Herring River). A total of 47 and 29 percent of recharged water discharges into surface drainage systems in the Sagamore and Monomoy flow lenses, respectively (fig. 23B). The complex interaction between groundwater and surface water would have a substantial effect on the response of the regional water table to a rise in sea level.

Increases in sea level result in inundation of emergent land by seawater and a corresponding decrease in land area (table $1 A$ ). About $26.4 \mathrm{mi}^{2}$ of land would be inundated by seawater following a 6 - $\mathrm{ft}$ rise in sea level, or about 8.8 percent of the land area in 2011 (table $1 B$ ). About 17.1 and $9.3 \mathrm{mi}^{2}$ of emergent land (or about 8.1 and 10.7 percent of the total land area) would be inundated on the Sagamore and Monomoy flow lenses, respectively, following a 6-ft rise in sea level (table $1 B$ ). These estimates assume coastal landform are static and do not account for erosional or depositional processes and include marginal coastal land for 2011 sea level. Increases in sea level also result in more freshwater discharge to freshwater receptors. This arises from increases in hydraulic gradients near existing streams and wetlands as well as discharge of freshwater into newly-formed wetlands and seeps resulting from higher water tables. About $306 \mathrm{ft}^{3} / \mathrm{s}$ of water discharges to existing wetland, streams, and seeps for 2011 sea level, or about 49 percent of the total groundwater discharge in the Sagamore and Monomoy flow lenses. The total amount of groundwater discharge to existing or newly-formed wetlands, streams, and seeps increased by about $85.2 \mathrm{ft}^{3} / \mathrm{s}$, following a 6 -foot rise sea level. Freshwater discharge on the Sagamore and Monomoy flow lenses following a 6-foot increase in sea level increased by about 50.4 and $24.9 \mathrm{ft}^{3} / \mathrm{s}$, respectively. Groundwater discharge to freshwater receptors represented a larger proportion of total groundwater discharge - about 61 percent - for a sea level 6 feet higher than in 2011. The proportional increase in streamflow following a rise in sea level indicates that surface-water features likely dampen the response of the water table to rising sea levels.
Table 1. Response of land area, water table altitudes, and depths to water for the Sagamore and Monomoy flow lenses to sea-level rises of 2, 4, and 6 feet above 2011 levels.

$[--$, zero $]$

\begin{tabular}{|c|c|c|c|}
\hline $\begin{array}{l}\text { Sea-level rise, } \\
\text { in feet }\end{array}$ & $\begin{array}{c}\text { Sagamore and } \\
\text { Monomoy lenses, } \\
\text { combined }\end{array}$ & Sagamore & Monomoy \\
\hline \multicolumn{4}{|c|}{ A. Land area, in square miles } \\
\hline 0 & 325.2 & 228.8 & 96.4 \\
\hline 2 & 321.0 & 226.3 & 94.7 \\
\hline 4 & 311.4 & 220.4 & 90.9 \\
\hline 6 & 298.8 & 211.7 & 87.1 \\
\hline \multicolumn{4}{|c|}{$B$. Surface inundation, in square miles } \\
\hline 0 & -- & -- & -- \\
\hline 2 & 4.2 & 2.5 & 1.7 \\
\hline 4 & 13.9 & 8.4 & 5.5 \\
\hline 6 & 26.4 & 17.1 & 9.3 \\
\hline \multicolumn{4}{|c|}{ C. Median water-table response, in feet } \\
\hline 0 & -- & -- & -- \\
\hline 2 & 0.62 & 0.51 & 0.91 \\
\hline 4 & 1.39 & 1.12 & 2.00 \\
\hline 6 & 2.11 & 1.72 & 2.91 \\
\hline \multicolumn{4}{|c|}{$D$. Median water-table response, as fraction of sea-level rise } \\
\hline 0 & -- & -- & -- \\
\hline 2 & 0.31 & 0.25 & 0.46 \\
\hline 4 & 0.35 & 0.28 & 0.50 \\
\hline 6 & 0.35 & 0.29 & 0.49 \\
\hline \multicolumn{4}{|c|}{ E. Depth to water less than 5 feet, in square miles } \\
\hline 0 & 24.9 & 15.6 & 9.3 \\
\hline 2 & 30.2 & 19.0 & 11.1 \\
\hline 4 & 32.5 & 20.6 & 12.0 \\
\hline 6 & 32.0 & 20.5 & 11.4 \\
\hline \multicolumn{4}{|c|}{$\begin{array}{l}\text { F. Depth to water less than } 5 \text { feet excluding areas inundated for a } \\
6 \text {-foot sea-level rise, in square miles }\end{array}$} \\
\hline 0 & 16.1 & 10.1 & 6.0 \\
\hline 2 & 20.6 & 13.1 & 7.5 \\
\hline 4 & 25.9 & 16.5 & 9.4 \\
\hline 6 & 32.0 & 20.5 & 11.4 \\
\hline
\end{tabular}

\section{Change in Water Table Altitudes}

The response of water table altitude to sea-level rise in an aquifer surrounded by saltwater is similar to the increase in sea-level altitude in a hypothetical aquifer with no surface water outlets and a land surface above the new water table (Masterson and Garabedian, 2007). Surface water drainages (including streams, drained wetlands, and pond outlets), which are common in most coastal aquifers, represent a 
fixed boundary altitude that can dampen the local water table response. Local hydraulic gradients and streamflow increase as water table altitude increases (fig. 3) and the response of the water-table altitude to sea-level rise becomes nonlinear. The aquifer system underlying the Sagamore and Monomoy flow lenses includes numerous surface water features that affect water table altitudes and hydraulic gradients, including streams, ponds with outlets, drained freshwater wetlands, and potential land surface seeps (fig. 23A). These features likely would dampen the response of the water table to sea-level rise as would any new surface water features that would be created when a rising water table intercepts land surface in areas with a thin vadose zone. This indicates that applying a linear offset to evaluate the potential effect of sea-level rise on depths to water would overestimate the effects in complex systems in areas with surface water features or a locally thin vadose zone.

The simulated response of water table altitude to a sea level $6 \mathrm{ft}$ above that of 2011 on the Sagamore and Monomoy flow lenses varies spatially from nearly $6 \mathrm{ft}$ to less than $0.1 \mathrm{ft}$ (fig. 24). The median response over the Sagamore and Monomoy flow lenses is about $0.62,1.39$, and $2.11 \mathrm{ft}$ for sealevel rises of 2, 4, and $6 \mathrm{ft}$, respectively, above sea levels in 2011 (table 1C). The median water table responses, expressed as a percentage of sea-level rise, are about 31 percent for a sea-level rise of $2 \mathrm{ft}$ and 35 percent for sea-level rises of 4 and $6 \mathrm{ft}$ (table $1 D$ ), indicating a large dampening of the effect of sea-level rise on the water table. The water table rises by more than $5 \mathrm{ft}$ in about 14 percent of the total land area after a 6- $\mathrm{ft}$ sea-level rise and by less than $1 \mathrm{ft}$ in about 29 percent of the land area Increases in water table altitude are largest near the coast where the increase is nearly equal to sea-level rise in some areas. The response is strongly associated with the location of surface water features, such as drained ponds and streams, that act as controls on the water table and where the response is smallest (fig. 24). The smallest responses (less than $0.1 \mathrm{ft}$ ) are in an area where the outlet from Johns Pond drains into the Quashnet River, the largest river on Cape Cod (fig. 24), suggesting that the influence of these large surface water features essentially causes the local water table to maintain the same altitude despite a 6-ft rise in sea level.

The water table response differs substantially between the Sagamore and Monomoy flow lenses (fig. 24). The median change in water table altitude for the Sagamore and Monomoy flow lenses was 1.72 and $2.91 \mathrm{ft}$, respectively, for a sea-level rise of $6 \mathrm{ft}$ above the sea level in 2011 (table 1C). This change represents responses of about 29 and 49 percent of the 6-ft rise in sea level (table 1D). The fractions of the total land area where the water table response exceeded $5 \mathrm{ft}$ after a 6 -ft rise in sea level were 12 and 18 percent for the Sagamore and Monomoy flow lenses, respectively. The Sagamore flow lens has more and larger surface water features than does the Monomoy flow lens; the portion of recharged water discharging into surface water drainages was 47 and 29 percent for the Sagamore and Monomoy flow lenses, respectively (fig. 23B). The ratio of the median fractional response to sea-level rise between the Sagamore and
Monomoy flow lenses (about 0.62) is essentially the inverse of the ratio of streamflow discharge (about 0.61 ). The area where the water table response was less than $1 \mathrm{ft}$ (or 16 percent of the total sea-level rise) is 36 percent of the total on the Sagamore flow lens, almost twice the 17 percent of the total land area on the Monomoy flow lens (fig. 24), indicating the importance of surface water features in dampening the effects of sea-level rise on the water table altitude and the limitation of linear corrections in real systems.

\section{Change in Depth to Water}

Dampening of the water table response to sea-level rise will limit groundwater inundation and the potential adverse effects of sea-level rise on infrastructure, though the response is also a function of land surface. A depth to water, defined as the vertical separation between the water table and land surface, of $5 \mathrm{ft}$ was chosen to represent a threshold for shallow depths to water in this analysis. The glacial terrain of Cape Cod exceeds an altitude of $300 \mathrm{ft}$ and can exceed $50 \mathrm{ft}$ in some areas near the coast; high land surface altitudes in coastal areas generally are more prevalent along the shore of Cape Cod Bay, near moraine and ice contact deposits (fig. $2 A$ ), but also occur in limited areas along the southern shore. The depth to water in 2011 ranged from essentially 0 to $239 \mathrm{ft}$ and averaged $38 \mathrm{ft}$ across both flow lenses. The mean depth to water on the Sagamore and Monomoy flow lenses is about 43 and $28 \mathrm{ft}$, respectively.

The thick vadose zone limits areas of shallow depths to water ( $5 \mathrm{ft}$ or less) to about $24.9 \mathrm{mi}^{2}$ (or about 8.4 percent of the total) of emergent land area, excluding salt marshes and surface waters for sea levels in 2011 (table $1 E$ ). About 12.0 and 15.9 percent of the total land area on the Sagamore and Monomoy flow lenses, respectively, has depths to water of $5 \mathrm{ft}$ or less. Increases in sea level will cause water table altitudes to increase and depths to water to decrease; the change will be a function of the amount of sea-level rise and complex groundwater/surface water interactions. Land areas with shallow depths to water for sea levels 2, 4, and $6 \mathrm{ft}$ above sea levels in 2011 are $30.2,32.5$, and $32.0 \mathrm{mi}^{2}$, respectively (table $1 E$ ). These represent 10.1, 11.1, and 11.7 percent of the total land area (excluding salt marshes and marginal coastal land), respectively (fig. 25). Many areas with shallow depths to water for sea levels in 2011 and intermediate sea-level rises of 2 and $4 \mathrm{ft}$ above the sea levels in 2011 are in areas likely to be submerged for larger sea-level rises. About $16.1 \mathrm{mi}^{2}$ of land area that will be emergent following a 6-foot rise in sea level (5.4 percent) has depths to water of $5 \mathrm{ft}$ or less for sea levels in 2011 (table $1 F$ ); this excludes areas expected to be submerged following a 6-ft sea-level rise and an assumption of static landforms (fig. 5). Shallow depths to water for the same land area (excluding areas submerged following a 6-ft sea-level rise) for sea levels 2, 4, and $6 \mathrm{ft}$ above the sea level in 2011 are 20.6, 25.9, and $32.0 \mathrm{mi}^{2}$, respectively (table $1 F$ ). Depths to water are greater in interior parts of the aquifer where responses are 


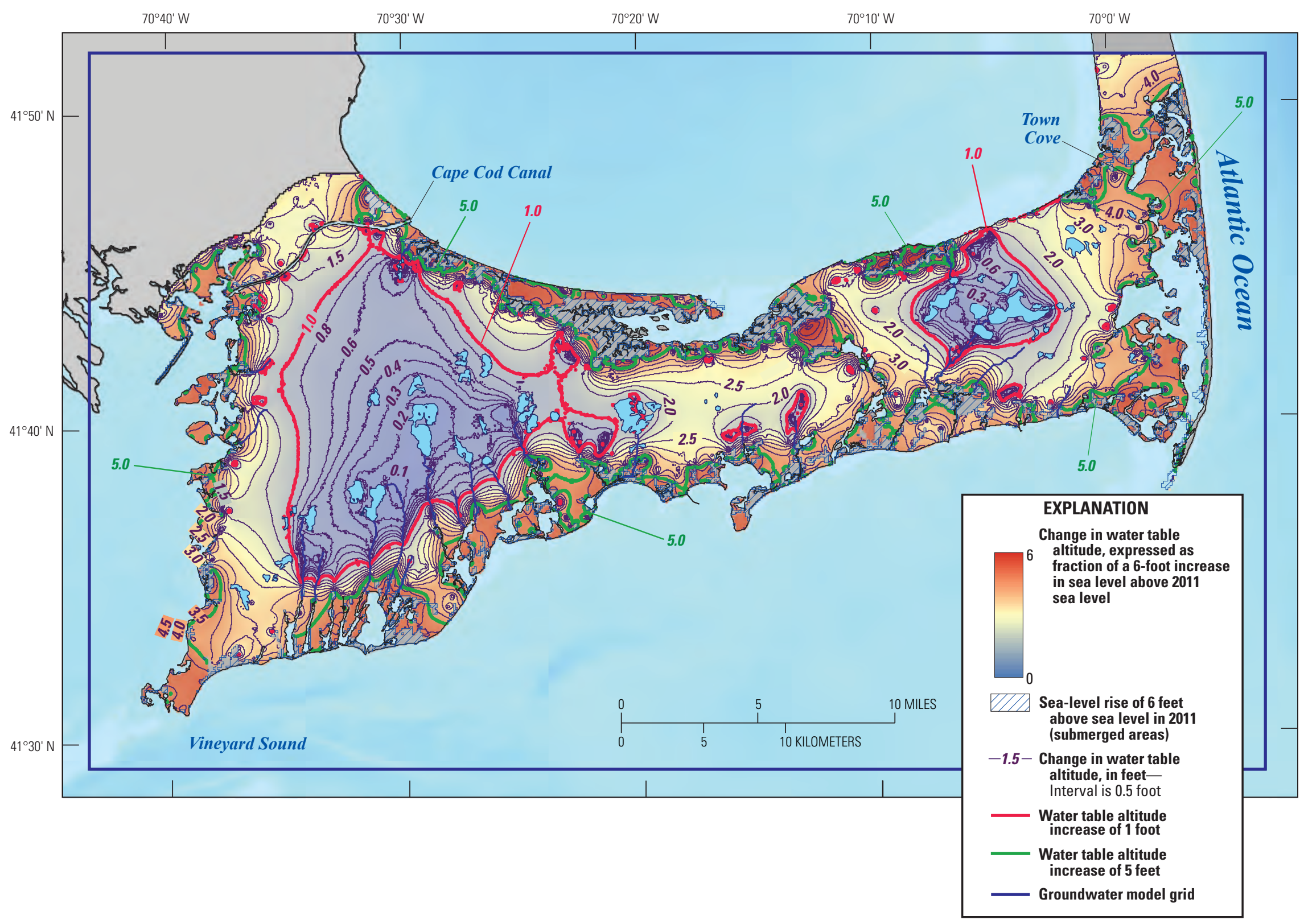

Figure 24. Change in water table altitude and fractional change as a function of sea level resulting from a sea-level rise of 6 feet above sea levels in 2011 for central and western Cape Cod, Massachusetts. 

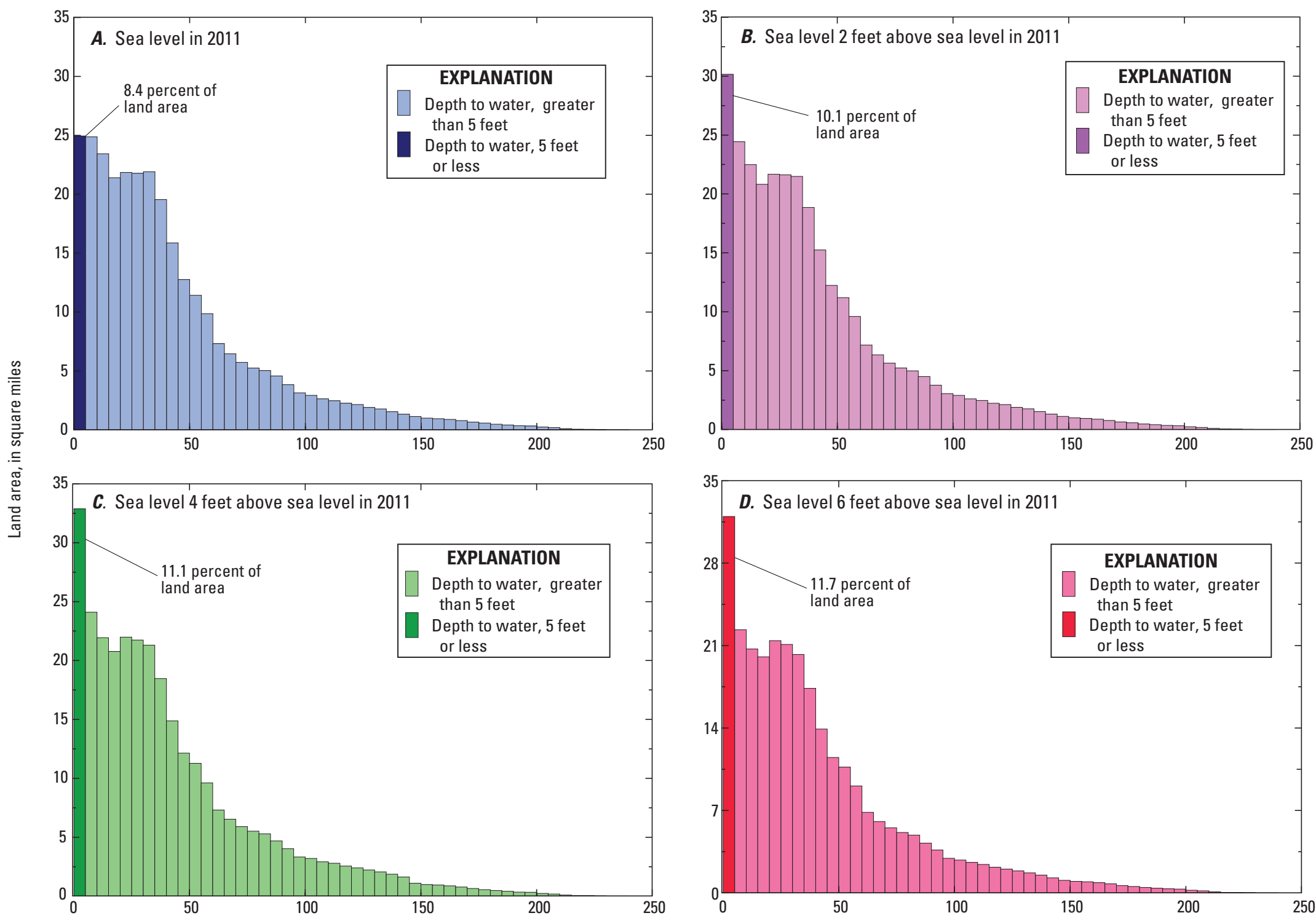

Depth to water, in feet

Figure 25. Depth to water for $A$, sea level in 2011 and $B, 2, C, 4$, and $D, 6$ feet above sea levels in 2011 in central and western Cape Cod, Massachusetts. The column that is shaded in each graph shows the land area with a depth to water of less than 5 feet (shallow depth); the percentages of land area with shallow depths to water are 6.8, 14.0, 13.4, and 12.1 percent for sea levels in 2011 and 2, 4, and 6 feet above 2011 sea levels, respectively. 
dampened by surface waters (fig. 5), resulting in a similar distribution of depths to water for values greater than $5 \mathrm{ft}$ for sea levels in 2011 and for future sea-level rises (fig. 25).

Shallow depths to water are primarily near the coast or adjacent to streams, wetlands, and ponds (fig. 26) where increases in gradients and streamflow dampen the response of the water table to sea-level rise (fig. 24). These areas include kettle holes and erosional channels and generally have steep topographic gradients (fig. 5), suggesting that depths to water increase greatly away from the surface waters. The difference in the distribution of depths to water for different sea levels is largest for areas categorized as shallow (5 ft or less; fig. 25) because shallow depths to water generally are near the coast where the water table response is greatest (fig. 26). The area underlain by shallow depths to water ( $5 \mathrm{ft}$ or less) does not change substantially on a regional scale following a 6-ft rise in sea level. The area underlain by shallow depths to water in land areas emergent following a 6-foot rise in sea level likely will increase by about $15.8 \mathrm{mi}^{2}$ (about 5.3 percent of total land area), following a 6-ft sea-level rise. Most of the additional land area with shallow depths to water is near the coast (fig. 26), particularly in low-lying coastal areas, such as Yarmouth, Dennis, and Harwich (fig. 27A) or Falmouth, Mashpee, and Bourne (fig. 27B) where effects of sea-level rise on a local scale may be more substantial. The area underlain by shallow depths to water generally does not increase substantially in inland areas (fig. 27B).

\section{Limitations of Analysis and Discussion}

Evaluating the potential effects of sea-level rise on depths to water in coastal aquifers requires understanding two sets of surfaces: land surface and current and future water tables. Limitations to the analysis, as described here, include those associated with estimation of land surface from lidar data and errors associated with model-calculated water tables. There also are limitations associated with the numerical models used to evaluate the response of the system to sea-level rise and the simplifying assumptions inherent in the conceptual model underlying those numerical models.

Limitations of these numerical models to accurately simulate the response of a system to changing hydrologic stresses include the assumption of steady-state conditions, the representation of hydrologic boundaries and the distribution of recharge, model discretization, the fit of simulated and observed conditions, and the accuracy of aquifer properties estimated from model calibration. The assumption of steadystate conditions is considered reasonable here because sea level likely will change over decadal time scales, whereas water table altitudes change over small, monthly or annual time scales in response to time-varying recharge (Walter and Whealan, 2005). The implicit representation of streams and coastal waters as head-dependent flux boundaries is also considered reasonable as these hydrologic features generally are areas of groundwater discharge where the volume of discharge is proportional to hydrologic gradients at those features. The discretization of the model was determined to be the minimum cell size needed to reasonably represent the hydrologic system yet result in a tractable model size. The model in this report represents uniform aquifer properties and simulates an average hydrologic condition within each model cell. The discretization of the groundwater flow model ( $400 \mathrm{ft}$ ) is considered reasonable for the regional-scale analysis of sea-level rise. Aquifer properties and the rate of natural recharge as estimated from calibration to observed hydrologic conditions are considered reasonable based on existing knowledge of the system and there generally is close agreement between observed water levels and streamflows and the simulated equivalents.

Land surface was estimated by spatially averaging $1-\mathrm{m}$ lidar data at an upscaled resolution of $100 \mathrm{ft}$. Simulated water tables for sea levels in 2011 and in the future were determined from numerical models at a resolution of $400 \mathrm{ft}$. The simulated water tables were downscaled by linear interpolation to a resolution of $100 \mathrm{ft}$, coincident with the estimated land surface. Depths to water were computed at a $100-\mathrm{ft}$ spatial resolution as the difference between the upscaled land surface and interpolated water tables. Uncertainties in both surfaces contribute to uncertainty in the estimated depths to water. The lidar data generally are accurate to within less than $(<) 5$ to $<20 \mathrm{~cm}$ (Heidemann, 2014) so it is assumed that the lidar data are accurate compared with other sources of potential uncertainty in this analysis. Spatially averaging lidar data at a $100-\mathrm{ft}$ resolution and using mean values to estimate depth to water is one source of uncertainty. The variability of individual lidar points within $100-\mathrm{ft}$ analytical cells had an average standard deviation of about $2.1 \mathrm{ft}$; the standard deviation ranged from essentially 0 to $32 \mathrm{ft}$. The variability generally was greatest within moraine and ice-contact deposits and smallest in outwash deposits (fig. 28).

The accuracy of the simulated water table can be partially inferred from the fit to observations as represented by the mean absolute residual between observed long-term water levels and their simulated equivalents. The mean absolute residuals for highly weighted water-level observations range from less than $0.05 \mathrm{ft}$ at several wells to $2.51 \mathrm{ft}$ near Town Cove (at the easternmost extent of the Monomoy flow lens; fig. 28). The mean absolute residual is about $0.3 \mathrm{ft}$, which is substantially smaller than the mean standard deviation ( $2.2 \mathrm{ft}$ ) of lidar at a $100-\mathrm{ft}$ spatial scale. The size of the mean absolute residual provides one qualitative measure of the relative importance of uncertainties in estimated land surface and simulated water tables in estimating depths to water and indicates that variability within the 100 - $\mathrm{ft}$ analytical cells likely is a larger potential source of uncertainty in estimating depths to water than is uncertainty associated with the fit between observed and simulated water table. This analysis does not address all aspects of uncertainty associated with the water table. 


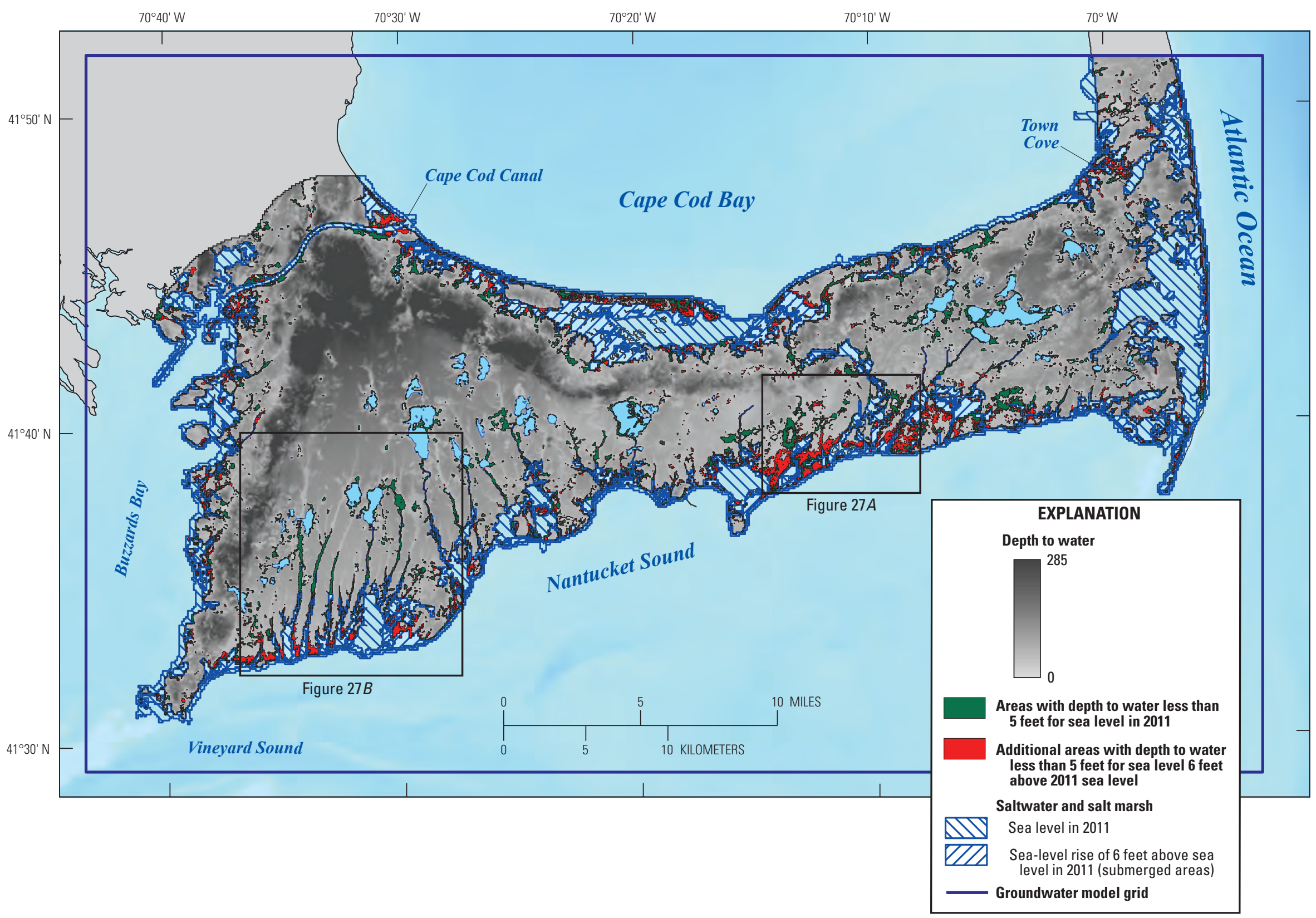

Figure 26. Depth to water resulting from a sea-level rise of 6 feet above sea levels in 2011 and areas with depths to water less than or equal to 5 feet for sea levels in 2011 and 6 feet above sea levels in 2011 in central and western Cape Cod, Massachusetts. 

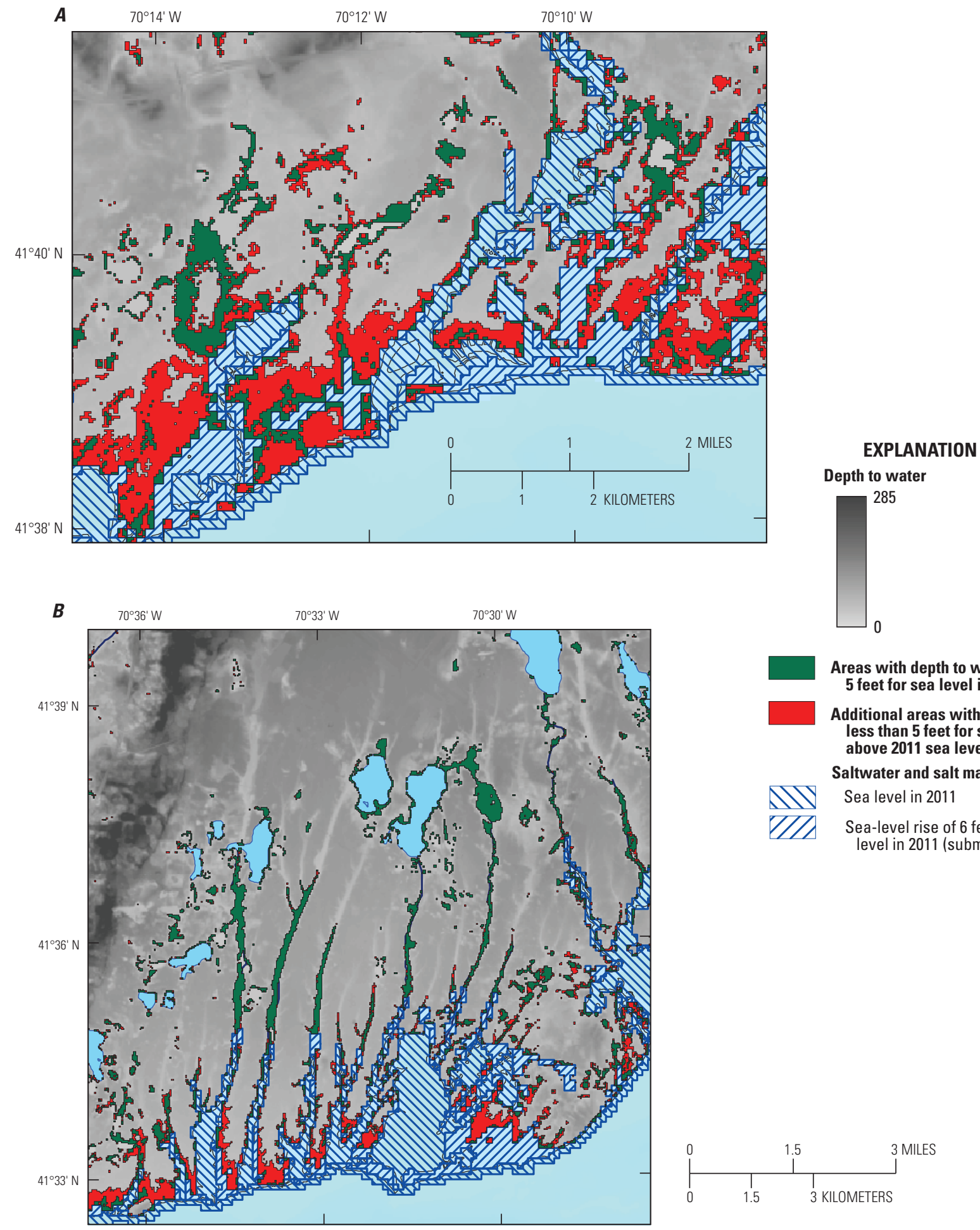

Figure 27. Depth to water resulting from a sea level 6 feet above sea levels in 2011 and areas with depths to water less than or equal to 5 feet for sea levels in 2011 and 6 feet above sea levels in 2011 for $A$, parts of Yarmouth, Dennis, and Harwich and $B$, Falmouth, Mashpee, and Bourne on Cape Cod, Massachusetts. Locations of areas shown in figure 26. Town boundaries shown on figure $9 A$. 


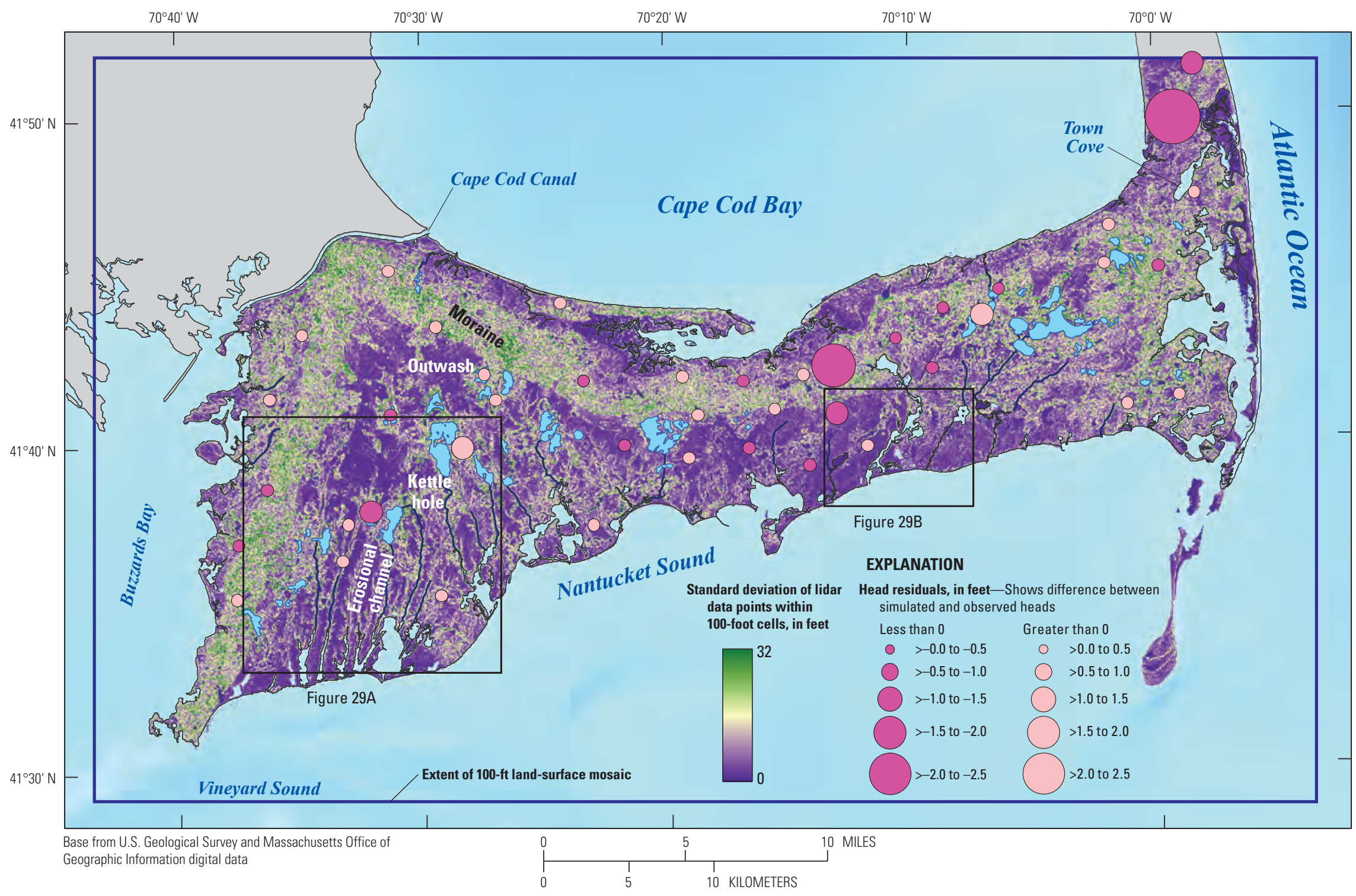

Figure 28. Standard deviation of 1-meter light detection and ranging (lidar) data points within 100-foot analysis blocks and absolute mean head residuals for the Sagamore and Monomoly flow lenses, Cape Cod, Massachusetts. 
The use of mean land surface altitude within the $100-\mathrm{ft}$ cells yields an average depth to water at that resolution. The use of minimum land surface to compute depths to water yields the minimum depth to water within the $100-\mathrm{ft}$ spatial resolution, and comparing areas of shallow depth to water $(5 \mathrm{ft}$ or less) estimated using mean and minimum land surface is an indicator of the effect of land surface variability on model predictions of shallow depths to water. The mean difference between mean and minimum lidar values within the $100-\mathrm{ft}$ cells ranged from essentially 0 to about $60 \mathrm{ft}$ (fig. 29) and averaged about $4.4 \mathrm{ft}$ across the Sagamore and Monomoy flow lenses. The difference generally is larger in moraines and smaller in outwash deposits and, similar to standard deviation, generally is associated with surficial geology.

The total area that was underlain by shallow depths to water in 2011 as computed from mean land surface was about $24.9 \mathrm{mi}^{2}$. The same area computed using minimum land surface was substantially larger, about $46.4 \mathrm{mi}^{2}$, suggesting that predictions of shallow depths to water will differ by use of mean or minimum lidar data. The use of minimum land surface altitude to define areas with shallow depths to water would increase that area by about 7 percent of emergent land area (excluding ponds and salt marshes) on the Sagamore and Monomoy flow lenses. Additional areas where depths to water would be considered as shallow when using minimum land surface generally are near areas where depths to water are considered shallow using mean land surface. These generally are near surface waters in inland areas (fig. 29A) and in low-lying areas near the coast (fig. 29B).

The assumption of static coastal landforms determines, in part, the conceptual model of hydrologic boundaries in the Cape Cod aquifer system and could affect the predicted response of water table altitude and depths to water to sealevel rise. The assumption of static landforms likely is not valid in dynamic coastal areas, such as barrier beaches (fig. 8A). These areas represent a small part of the region and generally have limited infrastructure so this limitation is not considered as important for this analysis. Barrier bars that separate areas at or below sea level from the sea could have a greater effect on the simulated response of the water table to sea-level rise and occur in numerous locations, including developed areas. These can be freshwater or brackish water features (ponds and wetlands) if the barrier bar is intact or can become saltwater estuaries if the bar is breached or removed by erosion. Conversion of a freshwater wetland to an estuary would likely cause changes to the freshwater/saltwater interface, local water table altitudes, and the response of the system to sea-level rise.

The lower part of Stewarts Creek along the southern shore of Cape Cod (fig. 5) was above sea level in 2011 and was separated from Nantucket Sound by a barrier bar (fig. 8B). The bar narrows but is intact following a 6-ft sea-level rise (assuming static coastal landforms). It is possible that the bar separating the creek from the ocean will be breached or removed through coastal erosion, and seawater will inundate about $4,000 \mathrm{ft}$ of the lower part of the creek, forming an estuary (fig. $8 B$ ). The elevated saltwater head in the estuary would likely cause the freshwater/saltwater interface to deepen; the altitude of the interface would likely change by about $140 \mathrm{ft}$ beneath the estuary to less than $10 \mathrm{ft}$ within about 2,000 ft east and west of the estuary (fig. 30A). The change in the interface is dampened to the north because the freshwater aquifer is truncated by bedrock. Changes in head and interface altitudes are similar, with a density ratio of between 30 and 37 , approaching the density ratio (40) between saltwater and freshwater (fig. 30A). The water table changes by about $3.5 \mathrm{ft}$ beneath the estuary and by more than $0.5 \mathrm{ft}$ within about $2,700 \mathrm{ft}$ of the estuary (fig. $30 \mathrm{~B}$ ). Water table altitudes increase by more than about $1 \mathrm{ft}$ within about 1,200 ft of the estuary, indicating that the effects of seawater inundation of low-lying back barrier areas generally are local in scale.

There are similar back-barrier features in a number of locations on the Sagamore and Monomoy flow lenses, particularly along the southern and western shores (fig. 5). A comparison of two simulated water tables wherein these features are represented as freshwater and saltwater features indicates that conversion of back-barrier freshwater features to estuaries increases the area with shallow depths to water ( $5 \mathrm{ft}$ or less) by about $0.4 \mathrm{mi}^{2}$, or an additional 1 percent of the total land area. This suggests that the potential effect of the conversion of fresh surface waters to estuaries, while potentially substantial in areas adjacent to the new estuaries, is not substantial at a regional scale. 


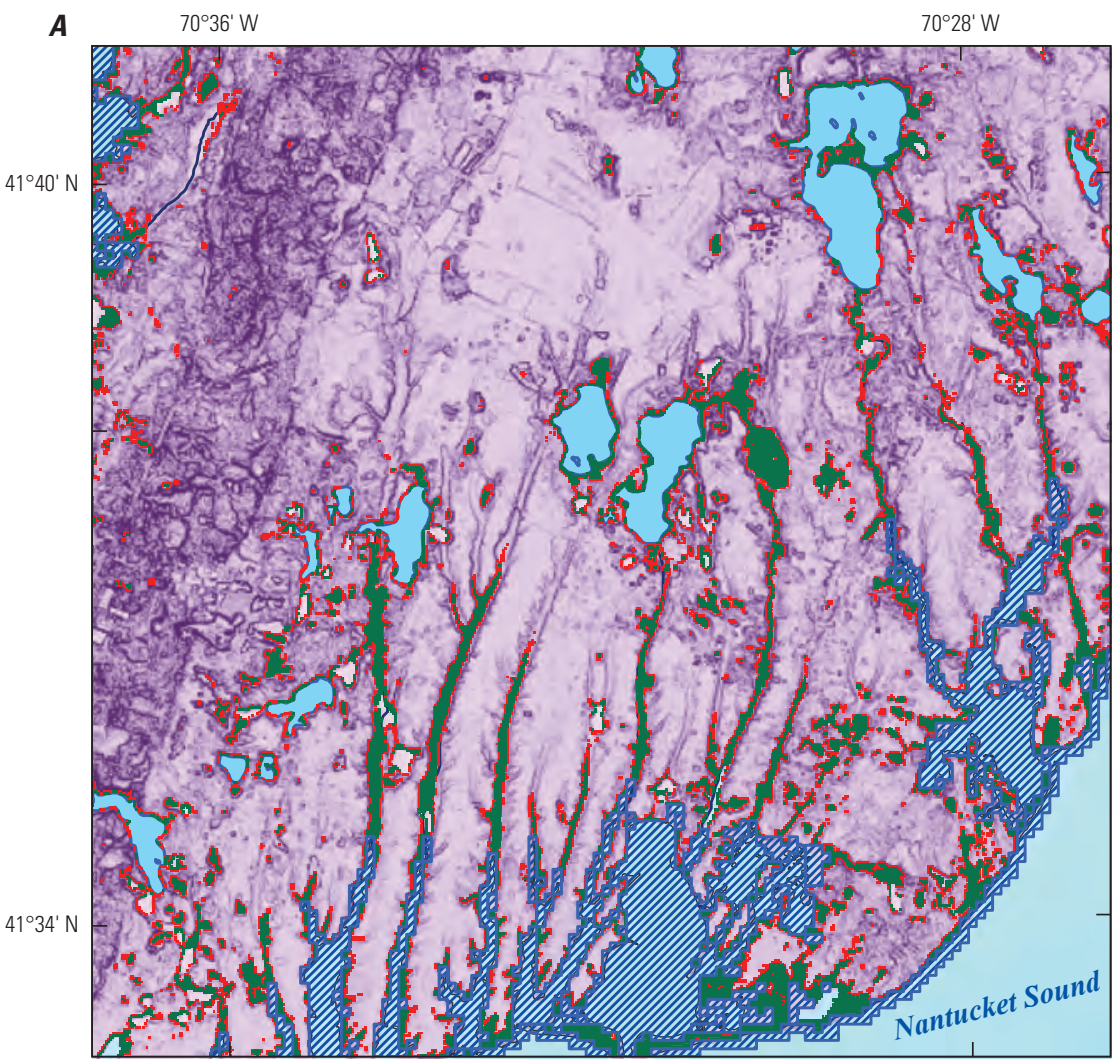

EXPLANATION

Difference between average

and minimum land-surface altitude within $100-\mathrm{ft}$ cells

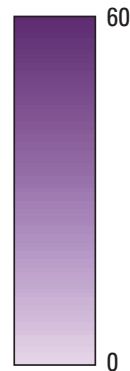

Areas with depth to water less than 5 feet for sea level in 2011 using mean lidar values within 100 -ft cells

Areas with depth to water less than 5 feet for sea level in 2011 using minimum lidar values within 100 -ft cells

VIIIIA Saltwater or salt marsh (excluded from analysis)

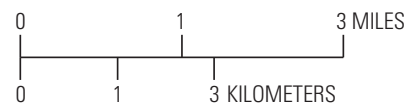

Base from U.S. Geological Survey and Massachusetts Office of Geographic Information digital data $70^{\circ} 13^{\prime} \mathrm{W}$ $70^{\circ} 09^{\prime} \mathrm{W}$

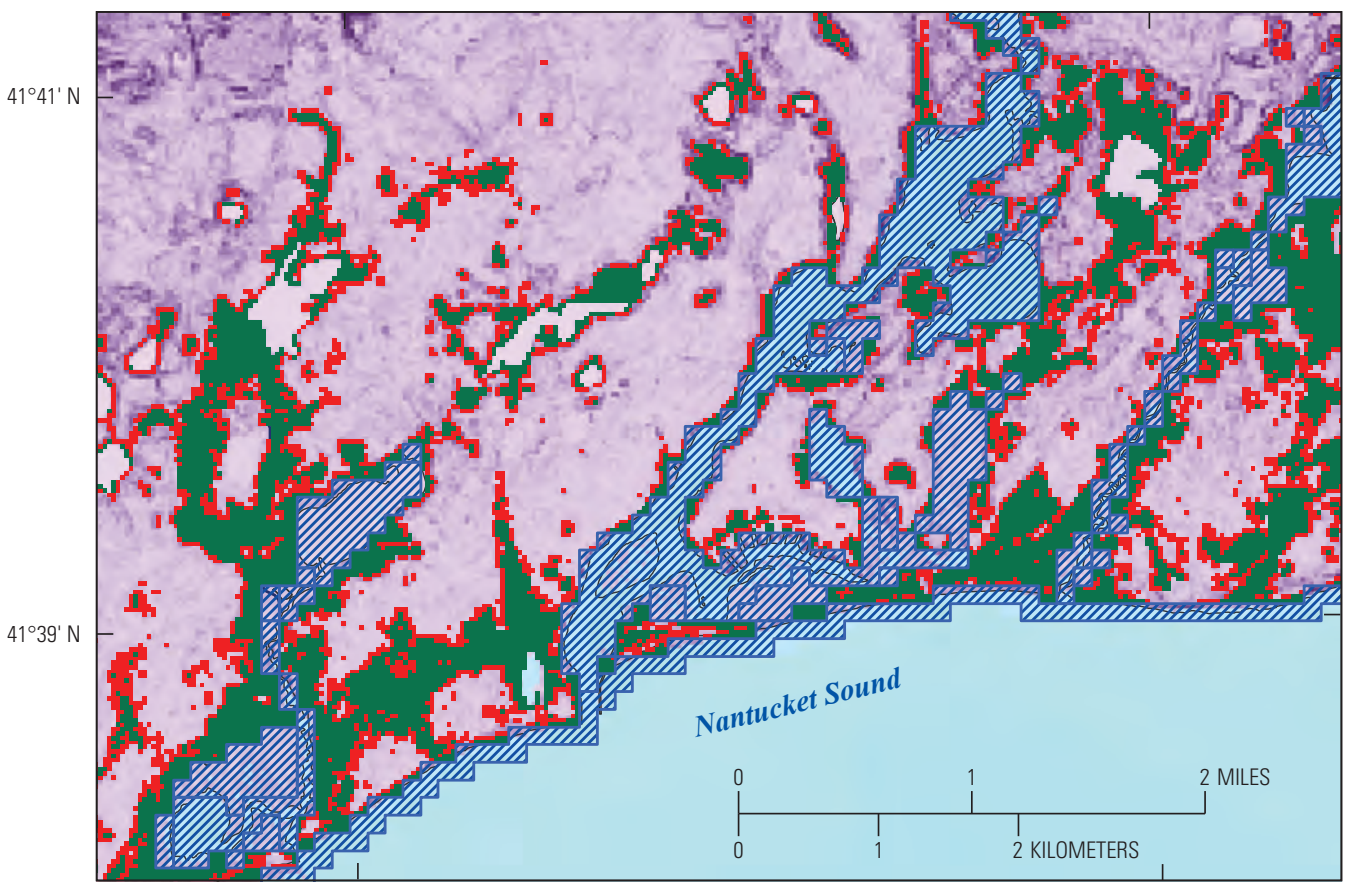

Base from U.S. Geological Survey and Massachusetts Office of Geographic Information digital data

Figure 29. Differences between mean and minimum 1-meter light detection and ranging (lidar) values within 100 -foot (ft) analysis blocks and areas with depth to water less than or equal to $5 \mathrm{ft}$ for sea levels in 2011 and $6 \mathrm{ft}$ above sea levels in 2011 for $A$, parts of Falmouth, Mashpee, Bourne, and Sandwich and B, Yarmouth, Dennis, and Harwich on Cape Cod, Massachusetts. Locations of areas shown in figure 28. Town boundaries shown on figure $9 A$. 


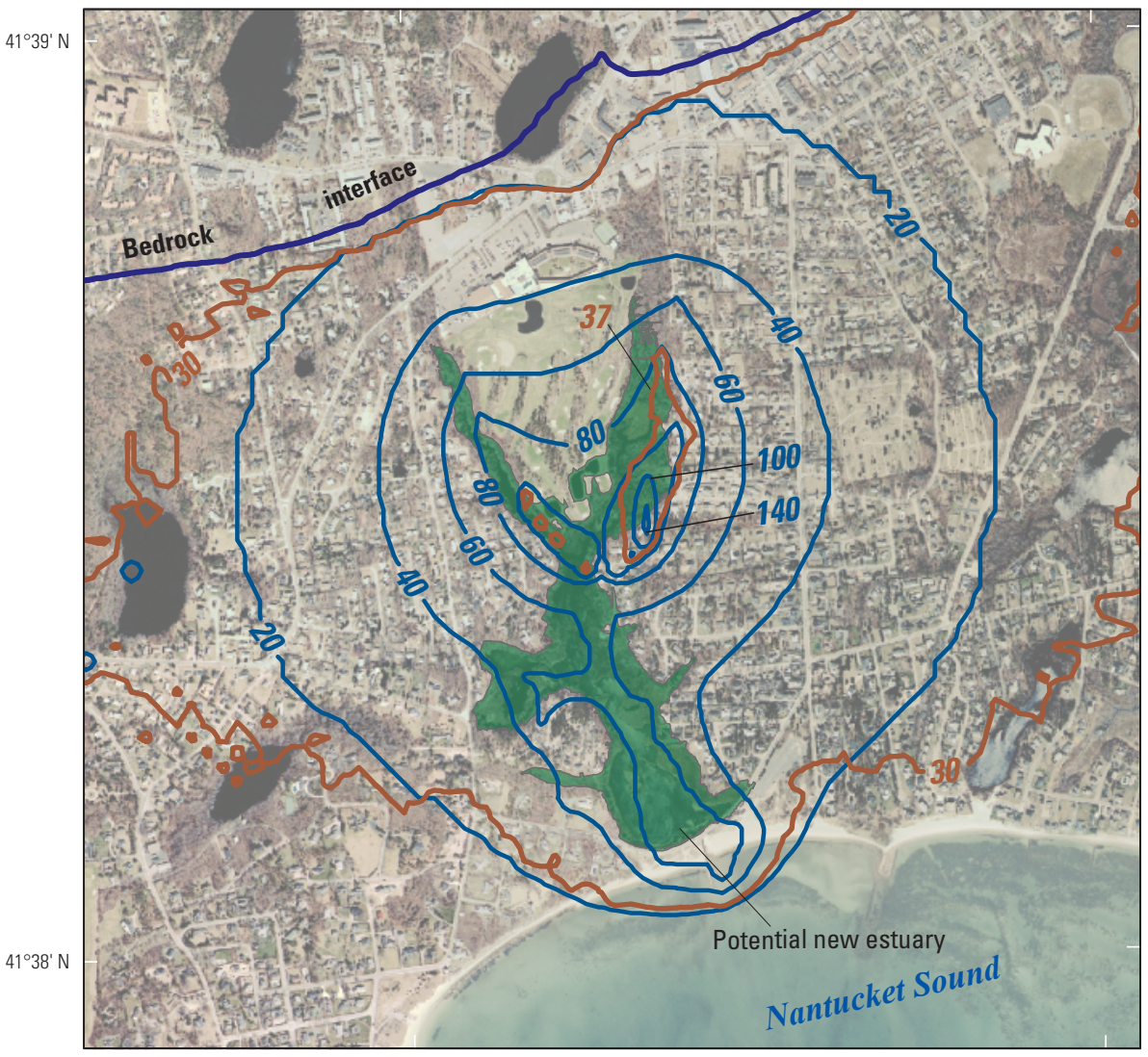

Base from U.S. Geological Survey and Massachusetts Office of Geographic Information digital data

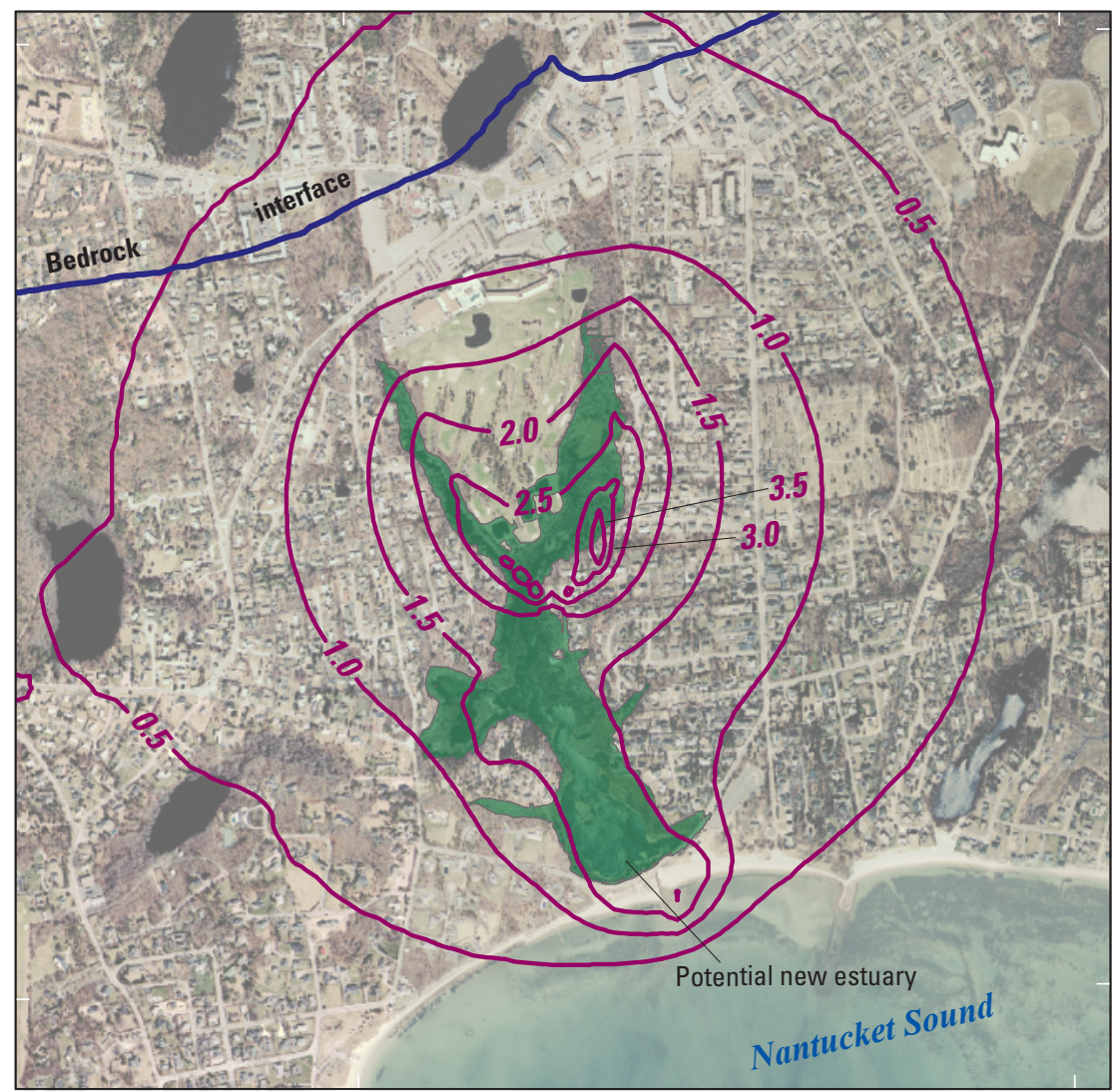

Base from U.S. Geological Survey and Massachusetts Office of Geographic Information digital data

\section{EXPLANATION}

$60-$ Decrease in freshwater/saltwater interface altitude, in feet

- 1.0 Increase in water table altitude, in feet

$30-$ Ratio of change in water table to interface altitude

Saltwater interface with bedrock

Figure 30. Changes in altitude of $A$, the simulated freshwater/saltwater interface and $B$, hydraulic head resulting from a barrier breach and formation of a potential new estuary for a sea level 6 feet above sea level in 2011 in Barnstable, Cape Cod, Massachusetts. 


\section{Summary}

The release of anthropogenic compounds into the atmosphere has caused an increase in atmospheric and oceanic temperatures since the mid-20th century. This warming likely will result in a rise in sea level that could be as high as 6 feet (ft) by 2100 , depending on emission scenarios, geographic region, and the dynamics of ice-sheet melting. An elevated sea level will likely result in seawater inundation of low-lying coastal areas and affect coastal aquifer systems, including possible saltwater intrusion, increased streamflows, and groundwater inundation. The latter could adversely affect infrastructurebasements, buried utilities, roads, and septic systems - in areas away from the coast. Cape Cod is a developed coastal area in southeastern Massachusetts. The underlying unconfined aquifer, which is the sole source of water to the region's communities, is surrounded on all sides by saltwater bodies and is therefore susceptible to the adverse effects of sea-level rise, particularly potential groundwater inundation of the region's infrastructure.

In 2015, the U.S. Geological Survey, in cooperation with the Association to Preserve Cape Cod, the Cape Cod Commission, and the Massachusetts Environmental Trust, completed an analysis of the potential effects of sea-level rise on the vertical separation between land surface and the water table - referred to as depth to water - on the Sagamore and Monomoy flow lenses on central and western Cape Cod. The Sagamore and Monomoy flow lenses are the largest and most populous of the six flow lenses that comprise the Cape Cod aquifer system. Light detection and ranging (lidar) data were used to estimate land surface altitudes and coastal geometries for sea level in 2011 and sea levels 2, 4, and $6 \mathrm{ft}$ above the levels in 2011. Water table altitudes were determined for different sea levels using two sets of implicitly linked numerical models: an existing two-dimensional model modified to simulate the position of the freshwater/saltwater interface and a newly calibrated three-dimensional model capable of simulating the response of the hydrologic system to sea-level rise. The analysis in this report was done at a common resolution of $100 \mathrm{ft}$ by spatially averaging 1-meter lidar data and interpolating water table altitudes, simulated at a resolution of $400 \mathrm{ft}$, to the common resolution.

Significant findings of the investigation are summarized as follows:

- About 626 cubic feet per second of recharge enters the aquifer at the water table. Simulated water table altitudes exceed $69 \mathrm{ft}$ on the Sagamore flow lens and $31 \mathrm{ft}$ on the Monomoy flow lens; hydraulic gradients are radially outward form these regional divides to wells and freshwater and saltwater receptors. Surface water features include drained ponds, streams, and wetlands. A substantial amount of water (about 41 percent of recharged water) discharges into these large receptors. About 21 percent of groundwater also leaves the aquifer at freshwater seeps and coastal marshes. There are more surface water drainages and more water leaves the aquifer at surface water drainages on the Sagamore flow lens than on the Monomoy flow lens: about 47 and 29 percent, respectively.

- The median response of the water table following a 6-ft sea-level rise, expressed as a percentage of the amount of sea-level rise, is an increase in simulated water table altitude of about 35 percent (or $2.11 \mathrm{ft}$ ) and is strongly affected by the presence of surface water drainages. The response is nearly the same as the sea-level rise near the coast and less than 1 percent of sea-level rise in some areas near large ponds and streams. The response is greater on the Monomoy flow lens because there are fewer surface water features to dampen the response and a smaller percentage of recharged discharges into surface water drainages. The presence of more surface water drainages on the Sagamore flow lens results in a more dampened response: about a 29 percent increase in water table altitude compared with a 49 percent increase on the Monomoy flow lens.

- Land surface altitude exceeds 300 and $50 \mathrm{ft}$ in northern parts of the Sagamore and Monomoy flow lenses, respectively, and the depth to water averages about $38 \mathrm{ft}$ across both flow lenses. About 24.9 square miles $\left(\mathrm{mi}^{2}\right)$ of the two flow lenses, or about 8.4 percent of the total land area, in 2011 had shallow depths to water, defined as $5 \mathrm{ft}$ or less. Shallow depths to water generally are in low-lying coastal areas or near surface waters (streams and ponds) in inland areas. The area underlain by shallow depths to water increases by about $15.9 \mathrm{mi}^{2}$, or an additional 5.6 percent of total land area, following a 6-ft rise in sea level. These additional areas also are in low-lying coastal areas and near ponds and streams.

Shallow depths to water ( $5 \mathrm{ft}$ or less) in 2011 were in a small part of the Sagamore and Monomoy flow lenses. The presence of streams, drained ponds and wetlands, and seeps likely will dampen the response of the water table and mitigate the effects of sea-level rise. The results of this analysis suggest that the potential for shallow depths to water and groundwater inundation are substantial in some low-lying coastal areas and near ponds and streams; however, the effects of sea-level rise on depths to water likely will not be regionally substantial owing to the region's thick vadose zone and the dampening of the water table response by surface water features. The results in this report indicate that infrastructure (basements, roads, septic systems, and utilities) likely would be affected in areas near the coast but not regionally. 


\section{References Cited}

Bakker, Mark, Schaars, Frans, Hughes, J.D., Langevin, C.D., and Dausman, A.M., 2013, Documentation of the seawater intrusion (SWI2) package for MODFLOW: U.S. Geological Survey Techniques and Methods, book 6, chap. A46, 47 p., accessed September 6, 2013, at http://pubs.er.usgs.gov/ publication/tm6A46.

Barlow, P.M., and Hess, K.M., 1993, Simulated hydrologic responses of the Quashnet River stream-aquifer system to proposed ground-water withdrawals, Cape Cod, Massachusetts: U.S. Geological Survey Water-Resources Investigations Report 93-4064, 52 p. [Also available at http://pubs.er.usgs.gov/publication/wri934064.]

Bjerklie, D.M., Mullaney, J.R., Stone, J.R., Skinner, B.J., and Ramlow, M.A., 2012, Preliminary investigation of the effects of sea-level rise on groundwater levels in New Haven, Connecticut: U.S. Geological Survey Open-File Report 2012-1025, 46 p., accessed June 12, 2013, at http://pubs.er.usgs.gov/publication/ofr20121025.

Boon, J.D., 2012, Evidence of sea level acceleration at U.S. and Canadian tide stations, Atlantic coast, North America: Journal of Coastal Research, v. 28, no. 6, p. 1437-1445. [Also available at http://dx.doi.org/10.2112/JCOASTRESD-12-00102.1.]

Cape Cod Commission, 2012, Cape trends-2002-2008: Barnstable, Mass., Cape Cod Commission, 25 p., accessed May 12, 2012, at http://www.capecodcommission.org/ resources/economicdevelopment/CapeTrends.pdf.

Chmura, G.L., Helmer, L.L., Beecher, C.B., and Sunderland, E.M., 2001, Historical rates of salt marsh accretion on the outer Bay of Fundy: Canadian Journal of Earth Sciences, v. 38, no. 7, p. 1081-1092. [Also available at http://dx.doi.org/10.1139/e01-002.]

Doherty, John, 2003, Groundwater model calibration using pilot points and regularization: Ground Water, v. 41, no. 2, p. 170-177. [Also available at http://dx.doi.org/10.1111/j.1745-6584.2003.tb02580.x.]

Doherty, John, 2010, PEST-Model-independent parameter estimation-User manual (5th ed., revised): Brisbane, Australia, Watermark Numerical Computing, 336 p., accessed May 12, 2012, at http://www.pesthomepage.org/ Downloads.php.

Doherty, J.E., and Hunt, R.J., 2010, Approaches to highly parameterized inversion-A guide to using PEST for groundwater-model calibration: U.S. Geological Survey Scientific Investigations Report 2010-5169, 60 p. [Also available at http://pubs.er.usgs.gov/publication/ sir20105169.]
Doherty, John, and Welter, David, 2010, A short exploration of structural noise: Water Resources Research, v. 46, no. 5, paper W05525, 14 p., accessed May 12, 2012, at http://dx.doi.org/10.1029/2009WR008377.

Drabbe, J., and Ghyben, W.B., 1888, Nota in Verband met de Voorgenomen Putboring Nabij Amsterdam: The Hague, Tijdschrift van het Koninklijk Instituut van Ingenieurs, v. 9, p. 8-22.

Environmental Chemical Corporation, 2007, Draft J-2 Range Groundwater Remedial Investigation and Feasibility Study: Prepared for the Army National Guard Impact Area Groundwater Study Program, January 2007, variously paged.

Ezer, Tal, Atkinson, L.P., Corlett, W.B., and Blanco, J.L., 2013, Gulf stream's induced sea level rise and variability along the U.S. mid-Atlantic coast: Journal of Geophysical Research and Oceans, v. 118, no. 2, p. 685-697. [Also available at http://dx.doi.org/10.1002/jgrc.20091.]

Fairchild, G.M., Lane, J.W., Jr., Voytek, E.B., and LeBlanc, D.R., 2012, Bedrock topography of western Cape Cod, Massachusetts, based on bedrock altitudes from geologic borings and analysis of ambient seismic noise by the horizontal-to-vertical spectral-ratio method: U.S. Geological Survey Scientific Investigations Map 3233, 1 sheet, 17-p. pamphlet, geographic information system, CD-ROM. [Also available at https://pubs.er.usgs.gov/publication/ $\operatorname{sim} 3233$.]

Favier, L., Durand, G., Cornford, S.L., Gudmundsson, G.H., Gagliardini, O., Gilet-Chaulet, F., and Le Brocq, A.M., 2014, Retreat of the Pine Island glacier controlled by marine ice-sheet instability: Natural Climate Change, v. 4, p. 117-121. [Also available at http://dx.doi.org/10.1038/ nclimate2094.]

Fienen, M.N., 2013, We speak for the data: Groundwater, v. 51, no. 2, p. 157. [Also available at http://dx.doi.org/10.1111/gwat.12018.]

Fienen, M.N., Muffels, C.T., and Hunt, R.J., 2009, On constraining pilot-point calibration with regularization in PEST: Groundwater, v. 47, no. 6, p. 835-844. [Also available at http://dx.doi.org/10.1111/j.1745-6584.2009.00579.x.]

Flood, J.F., and Cahoon, L.B., 2011, Risks to coastal wastewater collection systems from sea-level rise and climate change: Journal of Coastal Research, v. 27, no. 4, p. 652660. [Also available at http://dx.doi.org/10.2112/JCOASTRES-D-10-00129.1.]

Granato, G.E., 2009, Computer programs for obtaining and analyzing daily mean streamflow data from the U.S. Geological Survey National Water Information System Web site: U.S. Geological Survey Open-File Report 2008-1362, 123 p., 5 appendixes, 1 CD-ROM. [Also available at http://pubs.er.usgs.gov/publication/ofr20081362.] 
Harbaugh, A.W., 2005, MODFLOW-2005, The U.S. Geological Survey modular ground-water model-The groundwater flow process: U.S. Geological Survey Techniques and Methods, book 6, chap. A16, [variously paged]. [Also available at http://pubs.er.usgs.gov/publication/tm6A16.]

Harbaugh, A.W., Banta, E.R., Hill, M.C., and McDonald, M.G., 2000, MODFLOW-2000, the U.S. Geological Survey modular ground-water model - User guide to modularization concepts and the ground-water flow process: U.S. Geological Survey Open-File Report 2000-92, 121 p. [Also available at https://pubs.er.usgs.gov/publication/ofr200092.]

Heidemann, H.K., 2014, Lidar base specification (ver. 1.2, November 2014): U.S. Geological Survey Techniques and Methods, book 11, chap. B4, 67 p., appendixes, accessed June 23, 2015, at http://dx.doi.org/10.3133/tm11b4.

Herzberg, A., 1901, Die Wasserversorgung einiger Nordseebäder: Journal für Gasbeleuchtung und Wasserversorgung, v. 44 , p. $815-819$ and $842-844$.

Hirsch, R.M., 1982, A comparison of four streamflow record extension techniques: Water Resources Research, v. 18, no. 4, p. 1081-1088. [Also available at http://dx.doi.org/10.1029/WR018i004p01081.]

Hsieh, P.A., and Freckleton, J.R., 1993, Documentation of a computer program to simulate horizontal-flow barriers using the U.S. Geological Survey's modular three-dimensional finite-difference ground-water flow model: U.S. Geological Survey Open-File Report 92-477, 32 p. [Also available at http://pubs.er.usgs.gov/publication/ofr92477.]

Intergovernmental Panel on Climate Change, 2008, Climate change 2007-Synthesis report; Contribution of Working Groups I, II and III to the Fourth Assessment Report of the Intergovernmental Panel on Climate Change: Intergovernmental Panel on Climate Change, 73 p., accessed March 11, 2013, at http://www.ipcc.ch/publications_and_data/publications_and_data_reports.shtml.

Jevrejeva, S., Grinsted, A., and Moore, J.C., 2014, Upper limit for sea level projections by 2100: Environmental Research Letters, v. 9, letter 104008, 9 p. [Also available at http://dx.doi.org/10.1088/1748-9326/9/10/104008.]

Langevin, C.D., and Zygnerski, Michael, 2013, Effect of sealevel rise on salt water intrusion near a coastal well field in southeastern Florida: Groundwater, v. 51, no. 5, p. 781803. [Also available at http://dx.doi.org/10.1111/j.17456584.2012.01008.x.]

LeBlanc, D.R., Guswa, J.H., Frimpter, M.H., and Londquist, C.J., 1986, Ground-water resources of Cape Cod, Massachusetts: U.S. Geological Survey Hydrologic Investigations Atlas HA-692, 4 sheets. [Also available at http://pubs.er.usgs.gov/publication/ha692.]
Lentz, E.E., Stippa, S.S., Thieler, R.E., Plant, N.G., Gesch, D.B., and Horton, R.M., 2014, Evaluating coastal landscape response to sea-level rise in the northeastern United States-Approach and methods: U.S. Geological Survey Open-File Report 2014-1252, 26 p., accessed July 9, 2015, at http://dx.doi.org/10.3133/ofr20141252.

Levenberg, Kenneth, 1944, A method for the solution of certain nonlinear problems in least squares: Quarterly Journal of Applied Mathematics, v. 2, no. 2, p. 164-168.

Marquardt, D.W., 1963, An algorithm for least-squares estimation of nonlinear parameters: Journal of the Society of Industrial and Applied Mathematics, v. 11, no. 2, p. 431441. [Also available at http://dx.doi.org/10.1137/0111030.]

Massachusetts Office of Geographic Information, 2012, Office of Geographic Information (MassGIS): Massachusetts Office of Geographic Information Web site, accessed June 15, 2012, at http://www.mass.gov/anf/research-and-tech/ it-serv-and-support/application-serv/office-of-geographicinformation-massgis/.

Massachusetts Office of Geographic Information, 2014, MassGIS data download - LiDAR — 2011 northeast: Massachusetts Office of Geographic Information data, accessed April 12, 2015, at http://www.mass.gov/anf/research-andtech/it-serv-and-support/application-serv/office-of-geographic-information-massgis/datalayers/ftplidar-2011 northeast.html.

Massey, A.J., Carlson, C.S., and LeBlanc, D.R., 2006, Groundwater levels near the top of the water-table mound, western Cape Cod, Massachusetts, 2002-04: U.S. Geological Survey Scientific Investigations Report 2006-5054, 13 p. [Also available at https://pubs.er.usgs.gov/publication/ sir20065054.]

Masterson, J.P., 2004, Simulated interaction between freshwater and saltwater and effects of ground-water pumping and sea-level change, lower Cape Cod aquifer system, Massachusetts: U.S. Geological Survey Scientific Investigations Report 2004-5014, 78 p. [Also available at http://pubs.er.usgs.gov/publication/sir20045014.]

Masterson, J.P., and Barlow, P.M., 1997, Effects of simulated ground-water pumping and recharge on ground-water flow in Cape Cod, Martha's Vineyard, and Nantucket Island basins, Massachusetts: U.S. Geological Survey WaterSupply Paper 2447, 79 p., 1 pl. [Also available at https://pubs.er.usgs.gov/publication/wsp2447.]

Masterson, J.P., Carlson, C.S., and Walter, D.A., 2009, Hydrogeology and simulation of groundwater flow in the Plymouth-Carver-Kingston-Duxbury aquifer system, southeastern Massachusetts: U.S. Geological Survey Scientific Investigations Report 2009-5063, 110 p. [Also available at http://pubs.er.usgs.gov/publication/sir20095063.] 
Masterson, J.P., Fienen, M.N., Theiler, E.R., Gesch, D.B., Gutierrez, B.T., and Plant, N.G., 2013, Effects of sea-level rise on barrier island groundwater system dynamicsEcohydrological implications: Ecohydrology, v. 7, no, 13, p. 1064-1071. [Also available at http://dx.doi.org/10.1002/ eco.1442.]

Masterson, J.P., and Garabedian, S.P., 2007, Effects of sealevel rise on groundwater flow in a coastal aquifer system: Ground Water, v. 45, no. 2, p. 209-217.

Masterson, J.P., Stone, B.D., Walter, D.A., and Savoie, Jennifer, 1997a, Hydrogeologic framework of western Cape Cod, Massachusetts: U.S. Geological Survey Hydrologic Atlas HA-741, 1 sheet. [Also available at http://pubs.er.usgs.gov/ publication/ha741.]

Masterson, J.P., Walter, D.A., and Savoie, Jennifer, 1997b, Use of particle tracking to improve numerical model calibration and to analyze ground-water flow and contaminant migration, Massachusetts Military Reservation, western Cape Cod, Massachusetts: U.S. Geological Survey Water-Supply Paper 2482, 50 p. [Also available at http://pubs.er.usgs.gov/ publication/wsp2482.]

McDonald, M.G., and Harbaugh, A.W., 1988, A modular three-dimensional finite-difference ground-water-flow model: U.S. Geological Survey Techniques of WaterResources Investigations, book 6, chap. A1, 586 p. [Also available at http://pubs.er.usgs.gov/publication/twri06A1.]

National Oceanic and Atmospheric Administration, 2012, National Climatic Data Center: National Oceanic and Atmospheric Administration Web site accessed September 1, 2012, at http://www.ncdc.noaa.gov/.

National Oceanic and Atmospheric Administration, National Ocean Service, 2015a, National Ocean Service (NOS) Office of Coast Survey-U.S. bathymetric \& fishing maps: National Oceanic and Atmospheric Administration Web page, accessed July 28, 2015, at https://www.ngdc.noaa.gov/mgg/bathymetry/maps/nos intro.html.

National Oceanic and Atmospheric Administration, National Ocean Service, 2015b, What percentage of the American population lives near the coast?: National Oceanic and Atmospheric Administration Web page, accessed July 28, 2015, at http://oceanservice.noaa.gov/facts/population.html.

Oldale, R.N., 1992, Cape Cod and the islands-The geologic story: East Orleans, Mass., Parnassus Imprints, 205 p.

Oliver, M.A., and Webster, R., 1990, Kriging-A method of interpolation for geographical information systems: International Journal of Geographic Information Systems, v. 4, no. 3, p. 313-332. [Also available at http://dx.doi.org/10.1080/02693799008941549.]
Pachauri, R.K., and Meyer, Leo, eds., 2014, Climate change 2014-Synthesis report, Contribution of Working Groups I, II, and III to the Fifth Assessment Report of the Intergovernmental Panel on Climate Change: Geneva, Intergovernmental Panel on Climate Change, 151 p., accessed July 29, 2015, at http://ar5-syr.ipcc.ch/.

Paris, Adam, Bromirski, Peter, Burkett, Virginia, Cayan, Dan, Culver, Mary, Hall, John, Horton, Radley, Knuuti, Kevin, Moss, Richard, Obeysekera, Jayantha, Sallenger, Abby, and Weiss, Jeremy, 2012, Global sea level rise scenarios for the United States national climate assessment: National Oceanic and Atmospheric Administration Technical Report OAR CPO-1, 29 p. [Also available at http://scenarios.globalchange.gov/sites/default/files/NOAA SLR_r3_0.pdf.]

Parizek, B.R., Christianson, K., Anandakrishnan, S., Alley, R.B., Walker, R.T., Edwards, R.A., Wolfe, D.S., Bertini, G.T., Rinehart, S.K., Bindschadler, R.A., and Nowicki, S.M.J., 2013, Dynamic (in)stability of Thwaites glacier, west Antarctica: Journal of Geophysical Research-Earth Surface, v. 118, no. 2, p. 638-655. [Also available at http://dx.doi.org/10.1002/jgrf.20044.]

Peel, M.C., Finlayson, B.L., and McMahon, T.A., 2007, Updated world map of the Köppen-Geiger climate classification: Hydrology and Earth System Sciences, v. 11, p. 1633-1644. [Also available at http://dx.doi.org/10.5194/ hess-11-1633-2007.]

Phillips, Thomas, Rajaram, Harihar, Colgan, William, Steffen, Konrad, and Abdalati, Waleed, 2013, Evaluation of cryohydrologic warming as an explanation for increased ice velocities in the wet snow zone, Sermeq Avannarleq, west Greenland: Journal of Geophysical Research-Earth Surface, v. 118, no. 3, p. 1241-1256. [Also available at http://dx.doi.org/10.1002/jgrf.20079.]

Shaw, John, and Ceman, James, 1999, Salt-marsh aggradation in response to late-Holocene sea-level rise at Amherst Point, Nova Scotia, Canada: The Holocene, v. 9, no. 4, p. 439-451. [Also available at http://dx.doi.org/10.1191/095 968399668027869.]

Solomon, D.K., Poreda, R.J., Cook, P.G., and Hunt, A., 1995, Site characterization using ${ }^{3} \mathrm{H} /{ }^{3} \mathrm{He}$ ground-water ages, Cape Cod, MA: Groundwater, v. 33, no. 6, p. 988-996. [Also available at http://dx.doi.org/10.1111/j.1745-6584.1995. tb00044.x.]

Stone, B.D., and DiGiacomo-Cohen, M.L., 2009, Surficial geologic map of the Pocasset-Provincetown-CuttyhunkNantucket 24-quadrangle area of Cape Cod and islands, southeast Massachusetts: U.S. Geological Survey OpenFile Report 2006-1260-E, 19 p., 19 plates, 1:24,000 scale, data. [Also available at http://pubs.er.usgs.gov/publication/ ofr20061260E.] 
Thornthwaite, C.W., and Mather, J.R., 1957, Instructions and tables for computing potential evapotranspiration and the water balance: Centerton, N.J., Drexel Institute of Technology Publications in Climatology, v. 10, no. 3, 311 p.

Tonkin, M.J., and Doherty, John, 2005, A hybrid regularized inversion methodology for highly parameterized models: Water Resources Research, v. 41, no. 10, paper W10412, 16 p., accessed May 12, 2012, at http://dx.doi.org/10.1029/2005WR003995.

Uchupi, Elazar, Giese, G.S., Aubrey, D.G., and Kim, D.-J., 1996, The late Quaternary construction of Cape Cod, Massachusetts-A reconsideration of the W.M. Davis model: Geological Society of America Special Paper 309, 69 p. [Also available at http://dx.doi.org/10.1130/0-81372309-4.1.]

U.S. Army Corps of Engineers, 2011, Sea-level change considerations for civil works programs: Washington, D.C., U.S. Army Corps of Engineers Circular 1165-2-212, [variously paged]. [Also available at http://www.corpsclimate.us/ docs/EC_1165-2-212\%20-Final_10_Nov_2011.pdf.]

U.S. Department of Agriculture, Natural Resources Conservation Service, 1998, Soil quality resource concerns-Available water capacity: U.S. Department of Agriculture soil quality information sheet, January, 2 p. [Also available at http:/www.nrcs.usda.gov/Internet/FSE_DOCUMENTS/ nrcs142p2_051279.pdf.]

U.S. Department of Agriculture, National Resource Conservation Service, 2013, Web soil survey home page: U.S. Department of Agriculture Web page, accessed September 15, 2012, at http://websoilsurvey.sc.egov.usda.gov/App/HomePage.htm.

U.S. Geological Survey, 2015, Welcome to the USGS Center for Lidar Information Coordination and Knowledge: U.S. Geological Survey Web site, accessed August 3, 2015 , at http://lidar.cr.usgs.gov/.
Walter, D.A., 2013, The simulated effects of wastewatermanagement actions on the hydrologic system and nitrogenloading rates to wells and ecological receptors, Popponesset Bay Watershed, Cape Cod, Massachusetts: U.S. Geological Survey Scientific Investigations Report 2013-5060, 62 p., accessed March 16, 2016, at https://pubs.er.usgs.gov/publication/sir20135060.

Walter, D.A., and LeBlanc, D.R., 2008, Use of inverse-modeling methods to improve ground-water-model calibration and evaluate model-prediction uncertainty, Camp Edwards, Cape Cod, Massachusetts: U.S. Geological Survey Scientific Investigations Report 2007-5257, 57 p. [Also available at http://pubs.er.usgs.gov/publication/sir20075257.]

Walter, D.A., Masterson, J.P., and Hess, K.M., 2004, Ground-water recharge areas and traveltimes to pumped wells, ponds, streams, and coastal water bodies, Cape Cod, Massachusetts: U.S. Geological Survey Scientific Investigations Map I-2857, 1 sheet. [Also available at http://pubs.er.usgs.gov/publication/sim2857.]

Walter, D.A., and Whealan, A.T., 2005, Simulated water sources and effects of pumping on surface and ground water, Sagamore and Monomoy flow lenses, Cape Cod, Massachusetts: U.S. Geological Survey Scientific Investigations Report 2004-5181, 85 p. [Also available at http://pubs.er.usgs.gov/publication/sir20045181.]

Werner, A.D., and Simmons, C.T., 2009, Impact of sealevel rise on sea water intrusion in coastal aquifers: Groundwater, v. 47, no. 2, p. 197-204. [Also available at http://dx.doi.org/10.1111/j.1745-6584.2008.00535.x.]

Westenbroek, S.M., Kelson, V.A., Dripps, W.R., Hunt, R.J., and Bradbury, K.R., 2010, SWB-A modified Thornthwaite-Mather soil-water-balance code for estimating groundwater recharge: U.S. Geological Survey Techniques and Methods, book 6, chap. A31, 59 p., software. [Also available at http://pubs.er.usgs.gov/publication/tm6A31.]

Williams, R.S., Jr., and Hall, D.K., 1993, Glaciers, in Gurney, R.J., Foster, J.L., and Parkinson, C.L., eds., Atlas of Earth observations related to global change: Cambridge, U.K., Cambridge University Press, p. 401-422. 

For more information concerning this report, contact: Director, New England Water Science Center U.S. Geological Survey

10 Bearfoot Road

Northborough, MA 01532

dc_nweng@usgs.gov

or visit our Web site at:

http://newengland.water.usgs.gov

Publishing support by:

The Pembroke and Reston Publishing Service Centers. 
